\title{
Etienne-Pierre Ventenat (1757-1808) and the gardens of Cels and Empress Joséphine
}

\author{
Martin W. Callmander, Olivier D. Durbin, Hans-Walter Lack, \\ Patrick Bungener, Pascal Martin \& Laurent Gautier
}

\begin{abstract}
CALLMANDER, M.W., O.D. DURBIN, H.W. LACK, P. BUNGENER, P. MARTIN \& L. GAUTIER (2017). Etienne-Pierre Ventenat (1757-1808) and the gardens of Cels and Empress Joséphine. Candollea 72: 87-132. In English, English and French abstracts. DOI: http://dx.doi. org/10.15553/c2017v721a8

The intensive geographical exploration of the world, starting in the mid eighteenth century, resulted in the discovery of numerous plant species new to science of which many were subsequently introduced into cultivation in Europe. Etienne-Pierre Ventenat (1757-1808) contributed widely to this process. After the end of his curatorial and teaching commitments at Sainte-Geneviève Abbey in Paris he became an active botanist following in the footprints of his mentor Charles Louis L'Héritier de Brutelle (1746-1800). Ventenat was attracted by a trend of his period : publishing magnificent botanical books splendidly illustrated. He published three flower books from 1800 to 1808 on exotic plants recently brought to France from all over the world by various expeditions. Two flower books describe plants cultivated by Jacques-Martin Cels (1740-1806), an influential horticulturist who had built one of the most impressive plant collections of his period at Montrouge, just outside Paris. Another plant lover was Empress Joséphine (1763-1814). After her wedding with Napoléon Bonaparte (1769-1821), she bought in 1799 the splendid estate of Malmaison west of Paris. There the Empress assembled a remarkable collection of exotic plants, largely cultivated in her orangery and the "Grande Serre Chaude". She engaged Ventenat to describe her luxurious collection and the artist Pierre-Joseph Redoute (1761-1841), later known as the "Raphaël des fleurs", to depict the plants. This resulted in the famous flower book Jardin de la Malmaison, a masterpiece of botanical illustration. Ventenat, exhausted, passed away in 1808. His personal herbarium was bought in 1809 by Benjamin Delessert (1773-1847) whose herbarium was later donated to the City of Geneva in 1869. In his three flower books Ventenat treated a total of 343 plant names. A search in the herbaria of Geneva, Paris, Berlin and Madrid resulted in the finding of nearly all the original material relative to these names. A comprehensive list of names is provided here with comments on the origin of the plant material in the context of the explorations of this period, as well as information on typification and currently accepted names. In his three flower books Ventenat validated the names of 208 taxa (207 species and one variety) new to science: of these 67 are still accepted today as published while 52 are basionyms of names currently placed in another genera. Of these 208 names, lectotypification was not needed for 116 and the holotype has been found in G. For the remaining 92 names, 21 previous lectotypifications have been published but 5 of them needed a second-step lectotypification; 70 new lectotypes have been selected and one neotype. Further comments on the typification of ten species are also provided.
\end{abstract}

Addresses of the authors:

MWC, ODD, PB, PM \& LG: Conservatoire et Jardin botaniques de la Ville de Genève, C.P. 60, 1292 Chambésy, Switzerland. E-mail : martin.callmander@ville-ge.ch HWL: Botanischer Garten und Botanisches Museum Berlin-Dahlem, Freie Universität Berlin, Königin-Luise-Strasse 6-8, 14195 Berlin, Germany. 


\section{Résumé}

CALLMANDER, M.W., O.D. DURBIN, H.W. LACK, P. BUNGENER, P. MARTIN \& L. GAUTIER (2017). Etienne-Pierre Ventenat (1757-1808) et les jardins de Cels et de l'Impératrice Joséphine. Candollea 72: 87-132. En anglais, résumés anglais et français. DOI: http://dx.doi. org/10.15553/c2017v721a8

L'intense période d'exploration du monde qui s'étend du milieu du dix-huitième siècle jusqu'au début du dix-neuvième a permis la découverte de nombreuses plantes nouvelles pour la science, qui ont souvent été introduites par la suite en culture en Europe. Etienne-Pierre Ventenat (1757-1808) contribua largemment à ce processus. A la suite de son engagement en tant que conservateur et enseignant à l'Abbaye Sainte-Geneviève à Paris, il devint un botaniste à part entière, dans la lignée de son mentor Charles Louis L'Héritier de Brutelle (1746-1800). Ventenat s'est en particulier engagé dans un courant de l'époque: l'édition de magnifiques ouvrages botaniques somptueusement illustrés. Entre 1800 et 1808, il publia trois de ces ouvrages, consacrés aux plantes exotiques récemment ramenées en France par les nombreuses expéditions lancées à la découverte du monde. Deux de ces ouvrages décrivent les plantes cultivées par Jacques-Martin Cels (1740-1806), un horticulteur de renom qui avait constitué l'une des plus impressionnantes collections de plantes de cette période à Montrouge, juste en dehors de Paris. Une autre amoureuse des plantes était l'Impératrice Joséphine (1763-1814). Après son mariage avec Napoléon Bonaparte (1769-1821), elle acquit en 1799 la splendide propriété de Malmaison, à l'ouest de Paris. L'Impératrice y rassembla une remarquable collection de plantes exotiques dans son orangerie et dans sa «Grande Serre Chaude». Elle engagea Ventenat pour décrire cette somptueuse collection et le peintre Pierre-Joseph Redouté (1761-1841), connu par la suite comme le «Raphaël des fleurs», pour dessiner les plantes. Cette collaboration aboutit au fameux ouvrage Jardin de la Malmaison, un chef d'oeuvre de l'illustration botanique. Ventenat, épuisé, mourut en 1808. Son herbier personnel est acheté en 1809 par Benjamin Delessert (1773-1847). L'herbier Delessert sera ensuite donné à la Ville de Genève en 1869. Dans ses ouvrages botaniques illustrés, Ventenat traita un total de 343 noms. Une recherche dans les herbiers de Genève, Paris, Madrid et Berlin a permis de retrouver presque tout le matériel original lié à ces noms. Une liste complète en est fournie, avec des commentaires sur leur origine dans le contexte des explorations de l'époque, ainsi que des informations sur leur typification et le nom actuellement accepté. 208 taxa (207 espèces et une variété) nouveaux pour la science ont été validés par Ventenat dans ses trois ouvrages : 67 sont encore acceptés aujourd'hui tels qu'ils ont été publiés tandis que 52 sont des basionymes de noms actuellement acceptés dans un autre genre. Parmi ces 208 noms, 116 n' ont eu besoin d'aucun acte nomenclatural et l'holotype a été trouvé à G. Pour les 92 autres, 21 lectotypifcations antérieures ont été publiées dont 5 ont nécessité une deuxième étape; 70 nouveaux lectotypes ont été désignés, ainsi qu' un néotype. Des commentaires supplémentaires sur la typification de dix autres espèces sont également fournis.

\section{Keywords}

Ventenat - Cels - Empress Joséphine - Malmaison - Lamarck - Michaux - Jussieu - Australia - South Africa - United States - West Indies - Nomenclature - Age of Enlightenment - History of botany 


\section{Introduction}

Among its many treasures the Conservatoire et Jardin Botaniques de la Ville de Genève [CJBG] keep extremely rich and diverse herbaria. Global in approach and covering the plant, algal and fungal kingdoms these collections of permanently preserved specimens rank among the top ten in the world. Like its sister institutions the CJBG keep a permanently growing general herbarium $(\mathrm{G})$ and several historical, i.e. non-growing herbaria: Boissier's Flora orientalis herbarium (G-BOIS), the Pre-Linnaean herbarium (G-PREL), once known as the "Burman herbarium", the Prodromus herbarium of the Candolles (G-DC), and the Burnat herbarium (G-BU). As will be shown in this paper, the herbaria conserved by the CJBG are interlinked with the collections kept in other botanical centres in Europe, in particular those in Paris, forming in a sense an extensive network documenting the diversity of the plant, algal and fungal world.

Among the numerous acquisitions made by the CJBG over the last two centuries herbaria acquired from Paris played an important role, notably the vast botanical collection brought together by Benjamin Delessert (1773-1847), which was subsequently donated to the City of Geneva and incorporated into the general collection in G. In Paris, Delessert had, over several decades, amassed numerous botanical collections, including the herbarium of Etienne-Pierre Ventenat (1757-1808).

The aim of this paper is firstly to present the historical context of Ventenat's herbarium. This collection documents the contents of two private gardens: (a) the garden of Jacques-Martin Cels (1740-1806) in Montrouge, now a commune in the southern Parisian suburbs located c. $4.4 \mathrm{~km}$ from the city centre, and (b) the garden of Empress Joséphine (1763-1814) on her estate at Malmaison, now part of the commune of Rueil-Malmaison in the western suburbs of Paris located $12.6 \mathrm{~km}$ from the city centre. Ventenat's herbarium mirrors the contributions of its owner to name, describe and classify the masses of vascular plants new to science imported from all over the world to Paris around 1800. At the same time Ventenat was interested in publishing magnificent, fully illustrated flower books; three of them dealt with Cels's and the Empress Joséphine's gardens and were published between 1800 and 1808 .

The second part of this paper is devoted to the nomenclatural aspect of the 343 scientific names cited by Ventenat in these three flower books. Among those, Ventenat newly published 259 names; of these 208 were validly published. We have considered that, out of the 208 names that can confidently attributed to Ventenat and for which original material has been identified, G holds 116 holotypes. Information on the typification of these names is provided in Appendix II including barcodes of specimens. Among the 92 validly published names that need a nomenclatural action, 16 have previously been correctly lectotypified in the literature,
75 are lectotypified below (70 first step and 5 second step lectotypifications) and one neotype is designated. Five names required a lectotypification based on an illustration because no collection could be traced (two have been previously dealt with in the literature and three are treated below).

\section{Ventenat's contribution to botany}

\section{Ventenat and Cels's garden}

Etienne-Pierre Ventenat was raised to become a clergyman. In addition to his various commitments at Sainte-Geneviève Abbey in Paris (subsequently transformed into the Panthéon, the Lycée Henry IV and the Bibliothèque Sainte-Geneviève), Ventenat soon started to study botany and initially collaborated closely with Charles Louis L'Héritier de Brutelle (17461800) (Cuvier, 1809). Ventenat's first botanical publication was a dissertation on the reproduction of mosses (VENTENAT, 1792) followed the next year by the description of a genus new to science, i.e. Furcraea Vent. (Asparagaceae) (Ventenat, 1793). He subsequently published a treatment of Antirrbinum L. (Plantaginaceae) in the Encyclopédie Méthodique of Jean-Baptiste de Lamarck (1744-1829) (Ventenat, 1797). The Tableau du Règne Végétal selon la méthode de Jussieu [Tableau] (VENTENAT, 1799a) in four volumes summarized Ventenat's knowledge of general botany and made Jussieu's Genera Plantarum published in Latin more popular. All this was undertaken in parallel with his curatorial and educational activities, in particular at the Sainte-Geneviève Library (see LegÉE, 1977), of which he became "administrateur" in 1804. In his Tableau, Ventenat was the first to use the term "phanérogame" in opposition to "cryptogame", the latter established much earlier by Carl Linnaeus (1707-1778) (PorTères, 1964). In 1795 Ventenat was elected a member of the Institut de France (Anon., 2007). Starting in 1800 Ventenat followed in the footprints of his mentor L'Héritier and focused on the naming, describing, and classifying of plants new to science (LEGÉE, 1977) which, as a consequence of the increasingly intense geographical exploration of the world (Kintvilas, 2007), had arrived in the French capital.

Jacques-Martin Cels's interest in botany developed through his contacts with Bernard de Jussieu (1699-1777) and LouisGuillaume Le Monnier (1717-1799). Ruined by the French Revolution, he devoted himself totally to his passion and started to cultivate and sell plants. In Montrouge he managed to set up a spectacular collection of living plants, many of them exotic and on great demand at the time (Cuvier, 1809; WILLIAMs, 2001). Cels became an early member of the section "Economie rurale" of the Institut de France and his success as a nurseryman and collector of rare plants quickly drove him to become an illustrious French horticulturist. Silvestre (1806) reported: "Une branche de l'agriculture fixa particulièrement ses travaux les plus assidus; ce fut celle de la naturalisation 
des plantes exotiques. Il suivit cette carrière avec la supériorité d'un homme de génie; et la pépinière qu'il a formée et qu'il a entretenue pendant plus de vingt années, a été la plus belle qui fût en Europe." ["A branch of agriculture attracted in a special way his most assiduous activity; this was the acclimatation of exotic plants. He followed this line with the superiority of a genius; and the nursery which he had founded and maintained for more than twenty years was the most beautiful in Europe."] Cels had important connections with the botanical explorers of his time and was able to encourage them to collect new plants that would later expand his living collection. Among these, Jean-Guillaume Bruguière (1749-1798), Guillaume-Antoine Olivier (1756-1814), Pierre Marie-Auguste Broussonet (1761-1807) and André Michaux (1746-1802) brought Cels seeds from their historical expeditions (see below) (ANon., 1806). Cels always shared his knowledge with contemporary botanists and found in Ventenat someone who was willing to describe his unique collection (Lamy, 2008). At the same time Ventenat was interested in publishing magnificent, fully illustrated flower books, which meant for him a way to diffuse knowledge and make it available to students and agriculturists (LAMY, 2008), no doubt an important drive in relation to his teaching activities at Sainte-Geneviève. By describing and publishing the rare plants Cels cultivated in his garden, Ventenat "a élevé un monument à la gloire de Cels et à l'utilité publique" ["raised a monument to the glory of Cels and to public utility”] (Anon., 1806).

Pierre-Joseph Redouté (1761-1840), later known as the "Raphaël des fleurs", already enjoyed at the time a solid reputation as a plant illustrator (LAWALRÉE, 1996). Under the supervision of L'Héritier he had developed a natural gift for drawing critical parts of plants (STAFLEU, 1966) while working for the second volume of his master's Stirpes novae (L'HÉrITER, 17851786; see also Williams, 2001). L'Héritier later suggested that Redouté might work on another flower book dedicated to succulents. At the same time the former suggested that a 22 years old young Genevan student, Augustin-Pyramus de Candolle (1778-1841), might author the text of what would become the masterpiece Plantarum Succulentarum Historia (see Rowley, 1956). From Augustin-Pyramus's personal correspondence kept in the archives of the Candolle family in Geneva, it seems that other scientists were also involved in this project, i.e. Jean-Baptiste de Lamarck (1744-1829), René Louiche Desfontaines (1750-1833) and Joseph Deleuze (1753-1835) (CANDolle, 1798; see Bungener, 2008 for Candolle's scientific epistolary network).

Ventenat started in 1800 his first flower book: Descriptions des plantes nouvelles et peu connues cultivées dans le jardin de J. M. Cels [Descriptions] (Sylvestre, 1806; Cuvier, 1809). This work was published in ten parts between 1800 and 1803 (Ventenat, 1800-1803; see Stearn, 1939). The copper engravings in Descriptions were based on the works of several plant illustrators, among them Pierre-Joseph Redouté and Henri-Joseph Redouté (1766-1852). The former contributed 81 illustrations to this flower book (STAFLeU \& CowAn, 1986); the grisaille watercolours published as copper engravings in the Descriptions are kept in the Louvre in Paris, but have been deposited in the Musée National des Châteaux de Malmaison et de Bois-Préau in Rueil-Malmaison (shelf mark M.M. 40.47.592-40.47.703).

\section{Ventenat and Empress Joséphine's garden in Malmaison}

It is probably thanks to the publicity of the Plantarum Succulentarum Historia that Redoute caught the attention of Joséphine Vicomtesse de Beauharnais, who had married Napoléon Bonaparte (1769-1821) in 1796. The future Empress was born in Martinique and developed later in France a taste for luxurious gardens and fine conservatories. Three years after her wedding with Napoleon, she acquired the wonderful estate of Malmaison (Masson, 1913). The splendid country house (Fig. 1) was soon to be expanded on Joséphine's request: pieces of land were added to the property, an orangery and a large "Grande Serre Chaude" [large warm greenhouse] (Fig. 2) erected to satiate her passion for botany [see LACK (2004) for a story of the Château de la Malmaison and the reproduction of more watercolours by Auguste Garnerey (1785-1824)]. "C'est à Malmaison que s'opère, chez Joséphine, le Miracle des Fleurs." "It is in Malmaison, at Joséphine, where the Miracle des Fleurs works."] (Masson, 1913: 231). Joséphine first invited André Thouin (1747-1824), Head Gardener of the Jardin des Plantes at the Muséum national d'Histoire naturelle $[\mathrm{MNHN}]$ in Paris, to assist her in assembling a unique collection of exotic plants (Masson, 1913). Thouin had excellent relationships with famous gardeners, notably Cels but also with Louis-Claude Noisette (1772-1849). This is indicated by the correspondence between Thouin and Noisette (Noise t te, 1807). The link with the Muséum resulted in an exchange of rare plants that filled Joséphine's sumptuous conservatories. In a sense Redouté and Ventenat also bridged the gap between Cels's garden at Montrouge and Joséphine's garden at Malmaison. By the early nineteenth century, Malmaison had become the home to a unique collection of exotic plants.

The future Empress - her coronation took place only on 4 December 1804 - enjoyed introducing her renowned aristocratic guests to the wonderful living collection at Malmaison (Fig. 3). By 1803 at the latest she had started another great project : having a selection of her living collection documented in magnificent flower books made available to her prestigious visitors and the inner circle of the élite. She ordered what would become one of the greatest flower book ever - the majestic Jardin de la Malmaison [Jardin de Malmaison] in two volumes. Ventenat was hired for the descriptions of the plants and Pierre-Joseph Redouté hired to paint them. The 


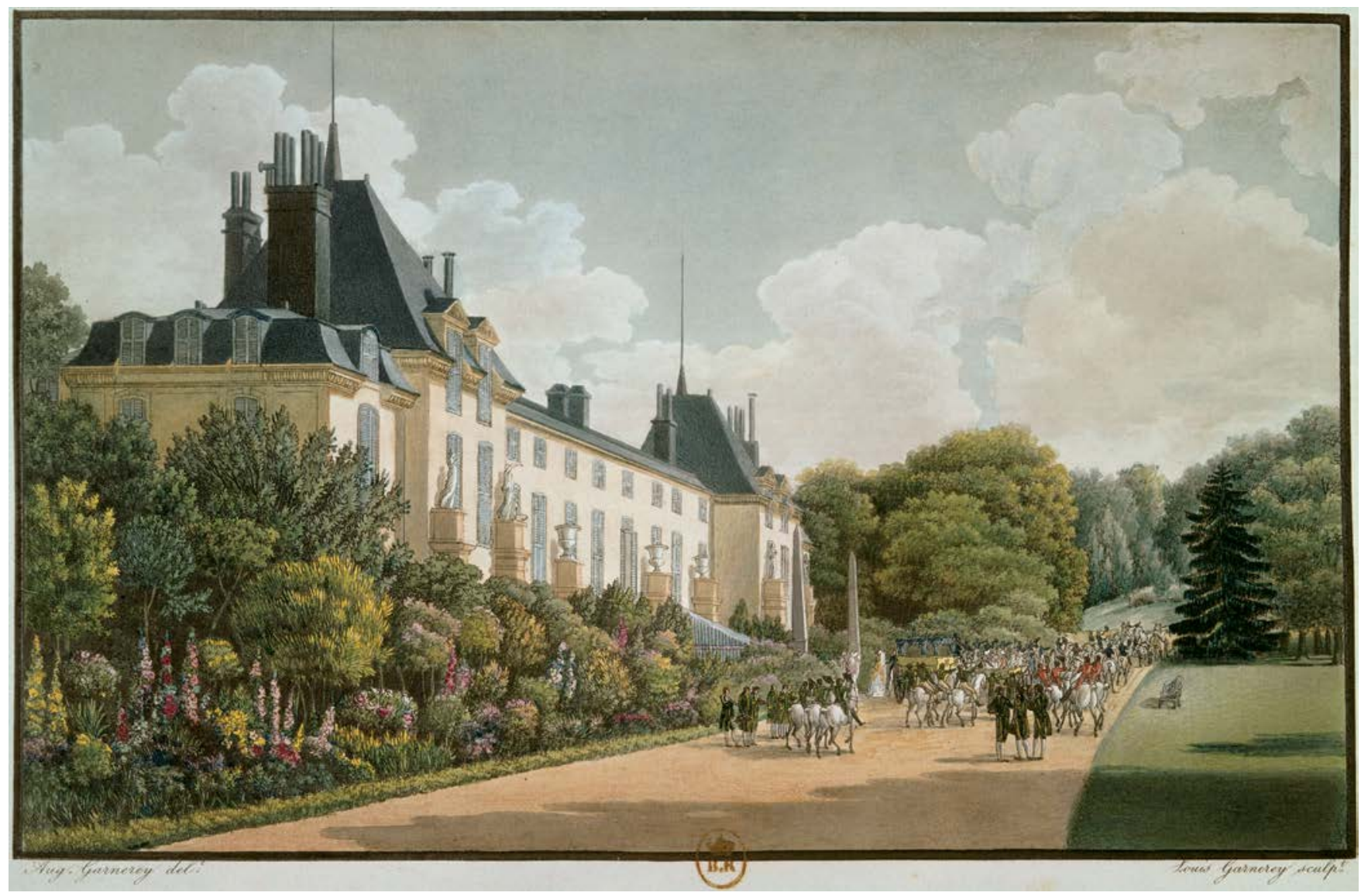

Fig. 1. - View of the Facade of Malmaison House seen from the Park. Watercolor, Auguste Garnerey (before 1824).

[Photo: @ RMN-Grand Palais / Agence Bulloz]

watercolours prepared by the latter and published as colour copper engravings in Jardin de Malmaison are kept largely in the Fitzwilliam Museum in Cambridge (shelf mark PD. 1221973). The Empress even promoted Ventenat as "son botaniste" ["her botanist"] and Redouté as "son peintre de fleurs" ["her flower painter"] (Nussac, 1930). The two volumes of Jardin de Malmaison were published in a total of 20 instalments between April 1803 and November 1805 (SteArn, 1939). An exquisite portrait of Joséphine painted by Robert Lefèvre (1755-1830) in 1805 and now in the Suermondt Ludwig Museum in Aachen shows the Empress with her new trophy - an open volume in large format, almost certainly the Jardin de Malmaison (LACK, 2004: 6), on which a flowering twig, probably of Calomeria amaranthoides Vent., has been placed. This fine work included 120 colour copper engravings by Allain based on Pierre-Joseph Redouté and the description of 161 plant species by Ventenat. The latter kept an eye on every detail of this great flower book and his name is forever associated with this major publication meticulously executed (LEGÉE, 1977).

In the meantime, Ventenat undertook another flower book entitled Choix de plantes: dont la plupart sont cultivées dans le jardin de Cels [Choix]. This work was published in ten parts between August 1803 and 1808 and dealt mainly with plants cultivated in Cels's garden but also in Joséphine's garden in Malmaison. Among the 60 copper engravings published, 12 were based on grisaille watercolours by Pierre-Joseph Redouté, the others on illustrations by Pierre-Antoine Poiteau (17661854) and Pierre Jean François Turpin (1775-1840), two other famous plant illustrators, among others. This material forms part of MS5041, kept at the Bibliothèque Centrale of the MNHN in Paris. The publication of this flower book had been planned before Jardin de Malmaison started to appear but was clearly postponed due to Joséphine's order in 1803. The refinement of the illustrations is not on the same level as in Jardin de Malmaison because less funding was available for this enterprise.

At the top of his fame Ventenat, exhausted and suffering from a liver disease, died of an "autumn fever" in 1808 at the age of 51 (Cuvier, 1809). Just before passing away, he had published his last book Decas generum novarum (VENTENAT, 1808a) containing the formal description of eight new genera (see Stearn, 1970).

Shortly after Ventenat's death, Empress Joséphine hired Aimé Bonpland (1773-1858) to succeed Ventenat at Malmaison in order to continue describing the plants growing in her 
garden. The publication of Description des plantes rares cultivées à Malmaison et à Navarre started in December 1812 and came to an end in April 1817 (Bonpland, 1812-1817; see Stearn, 1942). This was the last of the works initiated with support from Joséphine. The Empress died at Malmaison in May 1814 and never saw the book completed. Her death ended the great age of botanical book production of the Consulate and the Premier Empire, a period when all the technical and financial resources available at the time were brought together to describe and illustrate new and rare plants cultivated in France.

\section{Ventenat's herbarium acquired by Delessert}

Among the tasks Bonpland endorsed shortly after he was appointed by Empress Joséphine in 1808, one was to prevent Ventenat's widow from selling her husband's library and herbarium (Nussac, 1930). Ventenat left two children and died in poverty despite being employed by the Empress. "La Science n'enrichit guère souvent ses Maîtres, même protégés par leur Souveraine." ["Science rarely enriches its Masters, even if protected by their Sovereign."] (Nussac, 1930 : 177). The catalogue of Ventenat's library and herbarium was released in December 1808 and the auction took place between April $25^{\text {th }}$ and May $2^{\text {nd }}, 1810$. Delessert, a wealthy industrialist and naturalist, bought Ventenat's herbarium. This acquisition by Delessert underscored the MNHN's inability to acquire such large collections due to financial constraints. In reality, there was no acquisition policy at that time simply because no money was available (Lamy, pers. comm.). Ventenat's herbarium contained 14,000-15,000 collections including Ventenat's own herbarium, i.e. plants collected in Cels's and Joséphine's gardens and described in his three flower books, but also other collections acquired through his North-European correspondents, e.g. Olof Peter Schwartz (1760-1818) and Martin Vahl (1749-1804) (Ventenat, 1808b ; GuilLAUMin, 1833). Ventenat's herbarium also included plants collected by Jean-Baptiste Leblond (1747-1815) in Cayenne, or that were sent to the Empress Joséphine from Brasil (Fig. 4), but also collections by Hipólito Ruiz López (17541815) and José Antonio Pavón (1754-1840) from Chile and Peru and described in their famous Flora Peruvianae, et Chilensis (Ruiz \& Pavón, 1798-1802). In a letter archived at G sent by Delessert (1810) to Augustin-Pyramus de Candolle, the former explained in detail how exceptional this historical collection was and how proud he was to have acquired it: "J'ai pu faire l'acquisition de l'herbier de Ventenat qui a le mérite dêtre bien rangé et bien nommé. [...] Vous voyez mon cher ami que je pourrai avoir quelques plantes dignes de ce nom." ["I was able to acquire the Ventenat herbarium which has the merit of being well organized and named. [...] You see my dear friend that I may have some plants worthy of the name."]
Delessert passed away in 1847 . His extremely rich herbarium, one of the largest of his time, was given to the City of Geneva in 1869. Burdet et al. (1990) speculated that this donation was a consequence of Delessert's will in order to remember the place of birth of his mentor Jean-Jacques Rousseau (1712-1788). After a thorough research in the CJBG archives, Hocquet (2002) proposed an alternative hypothesis: according to a letter from Sophie Delessert to her cousin Alfred in 1868 (Hocquet, 2002: 110), Delessert's heirs did not want the herbarium to be donated to the MNHN because such a donation would remain in boxes without being integrated into the collections. As a matter of fact the Delessert herbarium would have largely duplicated the MNHN collections; in addition, the herbarium of Paris was sorely lacking in space. The collection had just moved to new premises which were already quite full (LAMY, 2013). Hocquet (2002) also puts forward that Alphonse de Candolle (1806-1893, son of Augustin-Pyramus) played a key role in this transaction with the support of his own family. In a letter addressed to the authority of the City of Geneva, the descendant of the Delessert family who was planning to donate Delessert's herbarium wrote: "Nous attacherions un grand prix à perpétuer ainsi le souvenir de l'interêt que MM. Delessert portaient aux sciences naturelles, et les liens de vive affection qui les ont toujours unis à la Suisse». ["We would attach great importance to perpetuating the memory of the Delesserts' interest in natural sciences and the bonds of affection which have always united them to Switzerland"] (Delessert et al., 1869: 311). Clearly the various explanations as to how the Delessert herbarium ended up in Geneva bear something in common: over generations the Delessert family had a strong link with Geneva and Benjamin seems to have been proud of his unquestionnable link and friendship with the French speaking part of Switzerland from where his family had originated, especially with the city of Geneva where his close botanist friend Augustin-Pyramus had lived.

\section{Nomenclature and typification of Ventenat's names}

\section{Context of names published}

Ventenat (1799a) validated the names of several plant families new to science which are still accepted today, i.e. Alismataceae, Asaraceae, Orobanchaceae or Smilaceae. These are not dealt with, neither are all those names published in VENTENAT (1793, 1797, 1799a, 1799b, 1800, 1808a). A single exception is the species Illicium parviflorum Michx. ex Vent., first validly published in Tableau and later cited in Descriptions tab. 22. 1801 which will be included in this contribution. 
All Ventenat's flower books were published in ten instalments over several consecutive years. In this context, it is important to underline that three of Ventenat's articles antedate names published in Ventenat's three flower books that were published between 1800 and 1808. It was already a common practice to validate new taxa in periodicals which had a faster editorial process than books delivered with illustrations (Lamy, pers. comm.).

A few examples illustrate this point: the generic name Caladium Vent. (Araceae) was cited in the third fascicle of Descriptions published in March 1801 as plate 30. In this treatment, Ventenat also cited the name of one new species, i.e. C. nymphaeifolium Vent., and of seven new combinations. However, those names had already been published between December 1800 and January 1801 in the fourth volume of the journal Magasin Encyclopédique (Ventenat, 1801; see Nicolson, 2006). Two further publications antedate taxa included in Choix. Ventenat (1807) explained that the publication of this flower book had to be interrupted after the fifth livraison in 1803 ending at plate 30 .
As explained above, there is no doubt that he had to put a great deal of effort into the demanding Jardin de Malmaison ordered by Joséphine in early 1803 at the latest (see above). As a result Ventenat presented to the "Institut de France" a note outlining and explaining the genera and species that he intended to publish in the next instalments of Choix. Therefore the names of the taxa appearing on plates 31 to 42 were first validly published in Ventenat (1807), not in Choix (12 new spp.; see Exell, 1938). Towards the end of his life VENTENAT (1808c) published some observations on the genera Samyda Jacq. and Casearia Jacq. that antedate the eighth instalment of the Choix (plates 43-47: 7 taxa in Casearia and 1 in Samyda) (see Exell, 1938). The earlier publication of these 29 names (Ventenat, 1799a, 1801, $1807,1808 \mathrm{c}$ ) has no nomenclatural repercussions except in their respective dates and places of publication because the text is clearly identical to that in his flower books. These names will therefore be treated in this article as if they were published in Ventenat's flower books (see Appendix II for details regarding their place of publication).

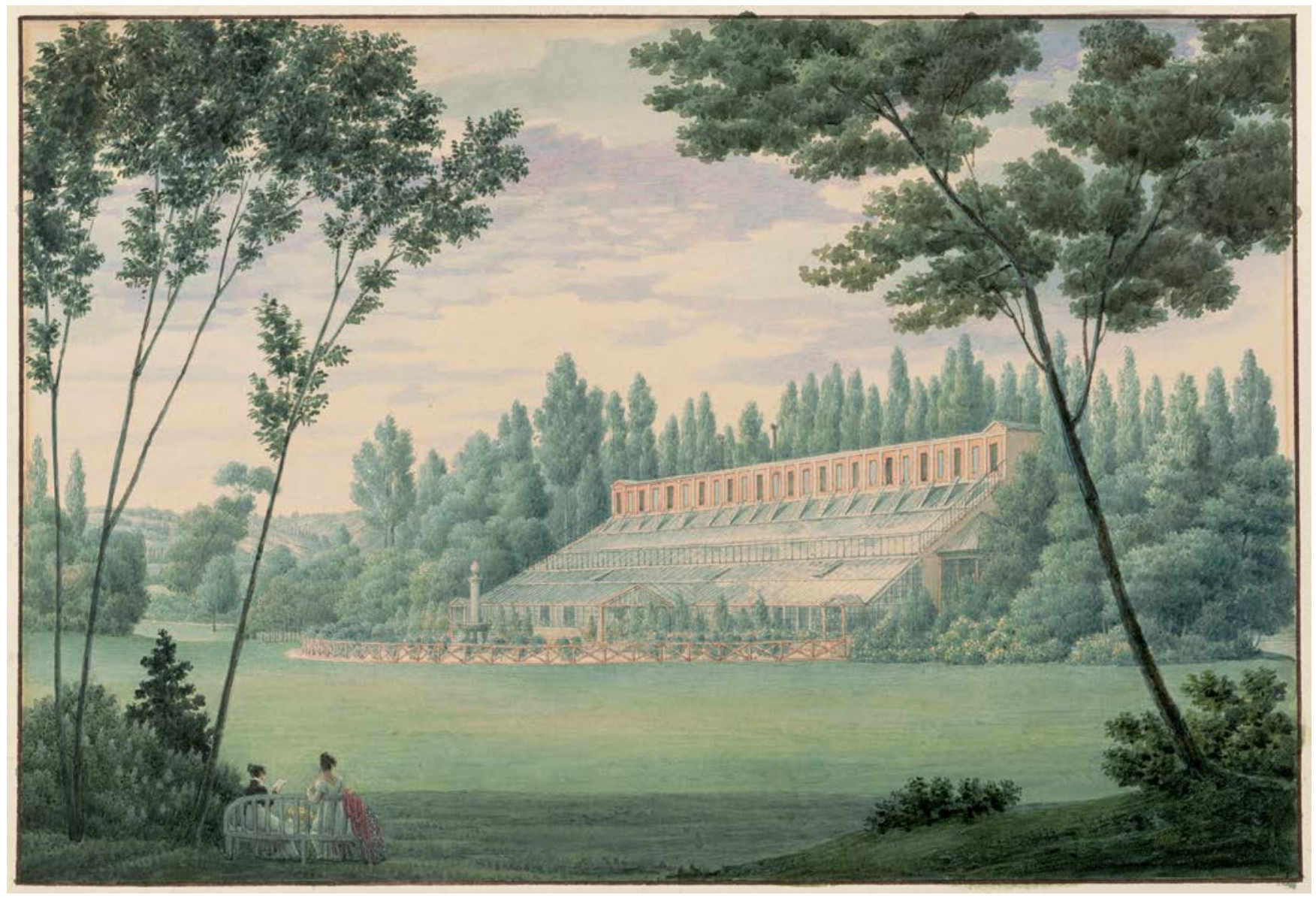

Fig. 2. - The "Grande Serre Chaude". Watercolor, Auguste Garnerey (before 1824).

[Photo: ๑ RMN-Grand Palais (Musée des châteaux de Malmaison et de Bois-Préau) / Daniel

Arnaudet / Jean Schormans] 


\section{Ventenat's herbarium and descriptions}

In the late eighteenth century, France was involved in the intensive exploration of the world and explorers, e.g. Michaux in North America (see Deleuze, 1804) or Bruguière and Olivier in Persia (see Bernard, 1997), brought back new plants to botanists and horticulturists in France. Plant knowledge made tremendous progress thanks to these explorers. Botanists were describing plant species based on living plants that were subsequently preserved as herbarium specimens. Ventenat had assembled his own herbarium that was to serve him to describe the plants dealt with in his flower books. These herbarium specimens are: (1) either the original material from the explorer(s) from which seeds were further used to grow plants in Cels's or Joséphine's garden and/or (2) the cultivated plants collected in the gardens by Ventenat himself. Ventenat also studied Jussieu and Lamarck's herbaria in Paris and received duplicates from both botanists (often clastotypes after studying the original at $\mathrm{P}$, see below). In addition, Ventenat received duplicates from his contemporaries, e.g. the Spanish botanist Antonio José Cavanilles (1745-1804) who had lived in Paris from 1777 to 1781, where he had learned botany with Thouin and Jussieu (López Piñero, 2004). Later Cavanilles moved to Madrid, and was appointed director of the Royal Botanical Garden and Professor of botany from 1801 to 1804. Subsequently he described many plants and genera brought back from the Spanish expeditions around the world taking place at this period (see González Bueno, 2002 and Correa revoluta Vent. under $\left.\mathrm{n}^{\circ} 21\right)$.

Each full entry [mentioned as "tab." below] in Ventenat's three flower books contains a full description giving the origin of the plant and often the names of the collectors who first brought the plants into cultivation. In the text supplementary to several plates [mentioned as "sub tab." below], Ventenat provided texts with information on other species that he was aware of in the respective genus. These plants had either already been named and described by earlier botanists or were represented in the Jussieu or Lamarck herbarium at P. Thus Ventenat introduced several new plant names in the addenda with no plates linked to them. These names are validated by a succinct Latin diagnosis, often followed by a note "ex Juss.” or “ex Lam.”. In these cases, three different situations have been encountered: (1) No collection has been located in the Ventenat herbarium and a lectotype at P is designated; (2) The collection in the Vententat herbarium is clearly a clastotype given to him by either Lamarck or Jussieu and a lectotype is designated at $\mathrm{P}$ where the plant that clearly served for its description is preserved and is much more complete than the fragment in his herbarium and (3) The plant is represented in Ventenat's herbarium by a complete specimen and we consider the $\mathrm{G}$ collection as the holotype and duplicate(s) as isotype(s).
MWC and ODD spent a considerable amount of time in $\mathrm{G}$ in order to bring to light all the collections linked to Ventenat's flower books because his herbarium, included in the Delessert collection as explained above, is now part of the general collection at G. Both Ventenat's handwriting and typical footer labels are easily recognizable (Fig. 5) (see also Burdet, 1979: 179-180) but such old specimens can potentially be found filed under several names in such a large herbarium. We used several online databases to trace back historical synonyms, among them in alphabetical order: the African Plant Database (APD, 2017), the Australian Plant Census (APC, 2017), the Australian Plant Name Index (APNI, 2017), the International Plant Names Index (IPNI, 2017), the Plant List (2017), Tropicos (2017), and the World Checklist of Selected Plant families (WCSP, 2017). We performed in depth searches in the $\mathrm{G}$ and $\mathrm{P}$ herbaria, also investigating the separate historical collections in $\mathrm{G}$, i.e. G-BOIS and G-DC, and in P, i.e. P-LA, P-JU, P-MICH and P-TRF. MWC further visited MA and received scanned images from the Webb herbarium (FI-W), and HWL investigated the Willdenow herbarium (B-W).

While in Paris in 1815 Augustin-Pyramus de Candolle received from Delessert 300 duplicates originating principally from the Ventenat herbarium: "J'ai reçu lors de mon séjour à Paris de Mr. Delessert en plantes étrangères surtout de l'herbier Ventenat." ["During my stay in Paris I received from Mr. Delessert in foreign plants especially from the Ventenat herbarium."] (CAndolle, 1830). These collections, found in G-DC mostly with the note "M. B. Delessert 1816" (Fig. 6), are considered original material and were part of Ventenat's herbarium before having been given to Candolle. This has some important nomenclatural repercussions.

\section{Foreword to nomenclature}

Among the names dealt with in Choix, Descriptions, and Jardin de Malmaison several are clearly linked to earlier names. These were notably published by Linnaeus, his son Carl Linnaeus filius (1741-1783), William Aiton (1731-1793), James Edward Smith (1759-1828), and Henry Charles Andrews (1794-1830). Several new names published by Ventenat are superfluous because Ventenat simply changed species epithets, providing a clear reference to a previously published name.

The typification of Ventenat's names in this article needs a clarification. We strictly followed the Code of Botanical Nomenclature (McNeill et al., 2012) and the very useful user's guide by Turland (2013). "A holotype is the one specimen or illustration used by the author, or designated by the author as the nomenclatural type. As long as it exists, it fixes the application of the name concerned" (McNeill et al., 2012). Since Ventenat neither subscribed to the type concept nor ever used the term 'type', we use the term "original material" for specimens clearly associated with his plant names. 
Regarding typification, the vast majority of cases corresponded to a limited number of categories that have been treated as follows: (1) A single specimen from a single gathering exists in Ventenat's herbarium at G; this must be considered as the holotype. As explained above, it can be either the plant cultivated in Montrouge or Malmaison or the material brought back by explorers. In the case of duplicates of this single gathering in other herbaria, duplicates are considered as isotypes. An exception has been made when specimens found in both Ventenat's herbarium and in G-DC represent a single gathering and are clearly labelled as "M. B. Delessert 1816" (Fig. 6) in the latter herbarium (see above and below, e.g. Anamenia coriacea Vent.). (2) Two or more specimens of a single or more gathering are extant in Ventenat's herbarium at $\mathrm{G}$ and/ or G-DC (e.g., Picridium ligulatum Vent.), i.e. the material collected in the wild and material of a cultivated plant or two cultivated plants clearly not from the same origin, e.g. Cels's garden and Joséphine's garden (see under Ancistrum repens Vent. for an example). In this case a lectotype is designated if not done previously. (3) When previous typification statements in the literature required the designation of a secondstep lectotype (Turland, 2013), the nomenclature of these names is also clarified. The remaining original material was cited as syntypes in various herbaria for straightforwardness in databasing those specimens.

All the elements of original material including lectotypes extant in Ventenat's herbarium at $G$ are available online via the Catalogue des Herbiers de Genève (2017); material extant at $\mathrm{P}$ is available via the Paris herbarium database (Sonnerat, 2017), and material extant at FI is available via the Firenze Herbarium Database (2017). These images are also accessible via the JSTOR Global Plants (2017) website. There is very little material of Ventenat's outside $\mathrm{G}$ and $\mathrm{P}$ (including the historical herbaria kept by both institutions). Stafleu \& Cowan (1986) mentioned duplicates at $\mathrm{C}$ and $\mathrm{W}$ but searches through online databases revealed only a couple of them. Delessert was however very generous and his visitors often received specimens in exchange for determination in his personal herbarium. It is likely therefore that further Ventenat duplicated material may well be found, especially in MPU. Duplicates found so far except in G-DC are mostly clastotypes, i.e. fragments of holotype specimens given to the authors when revising the taxonomy or nomenclature of a given genus.

\section{Ventenat's taxonomic legacy}

The names of eighteen genera were cited between 1800 and 1808 in Ventenat's three flower books: Choix, Descriptions, and Jardin de Malmaison. Thirteen are accepted or conserved names [nom. cons.], three are rejected names [nom. rejic.], one is synonym of a previously published generic name, and one is an illegitimate name [nom. illeg.] (See Appendix I). All those genera were published in Ventenat's three flower books except Caladium published in Ventenat (1801), Poiretia Vent., Poitea Vent., Riedlea Vent., and Turpinia Vent. published in Ventenat (1808).

Ventenat cited a total of 343 names in his three flower books. The geographical origin of these names is listed in Fig. 7. It is not surprising that more than $20 \%$ of the plants that were growing in Cels's and Joséphine's garden came from the Southern Territories (Australia, New Zealand and Norfolk Island). This is the consequence of Cels's excellent relationship with England, notably with Joseph Banks (1743-1820), who had taken part in the first circumnavigation of the world with James Cook in 1768-1771 and later had been elected President of The Royal Society (LAck, 2004). Banks also supported the participation of botanists during the second circumnavigation of the world headed by Cook with Johann Reinhold Forster (1729-1789) taking part (Allorge \& IKor, 2003). In addition, Ventenat received seeds from naturalists and sailors who took part in the Baudin Expedition (1800-1803) to the Southern Territories, i.e. Nicolas Baudin (1754-1803), and Jacques Félix Emmanuel Hamelin (1768-1839) (see Bonnemains, 2000). Other plants were linked to the D'Entrecasteaux Expedition - a French expedition in the southern seas from 1791 to 1794 in the search of the missing ships of the La Pérouse Expedition - through Jacques-Julien Houtou de La Billardière (17551834) and Ventenat's brother, Louis (1765-1794) (AlLORgE \& Iков, 2003). North America and South Africa are the origin of nearly $15 \%$ of the plants, a fact which underlines the intensive botanical explorations going on in these regions. Michaux was the principal supplier of plants from North America where he travelled to Illinois and Carolina in 17861797 together with his son François André (1770-1855) who was to come back to France in 1790 (Deleuze, 1804). Besides Cels's good relationship with Michaux father and son (Anon., 1806), this also demonstrates the good relationship between André Michaux and Ventenat. Correspondence archived in the "Bibliothèque de l'Institut de France" in Paris testifies to the great respect that Michaux had for Ventenat (Michaux, 1786). In these letters, among others, sent by Michaux from North America and Persia, we learn how meticulous he was in collecting seeds and plants and how respectful he was to "Citoyen Ventenat, Membre de l'Institut". Each of these letters ended by: "Je suis très respectueux, Monsieur - de votre humble et très respectueux serviteur, André Michaux" ["I am most respectfully, Sir - from your humble and very respectful servant, André Michaux"]. As Ventenat described all the North American plants that were growing in Cels's and Joséphine's garden, several names later described by Michaux (1803) in the two volumes of his Flora Boreali-Americana are illegitimate because they represent later isonyms of Ventenat's names. In addition, Michaux described also some of these species in different genera and/or made use of a different epithet. Type collections are therefore the same between the two 


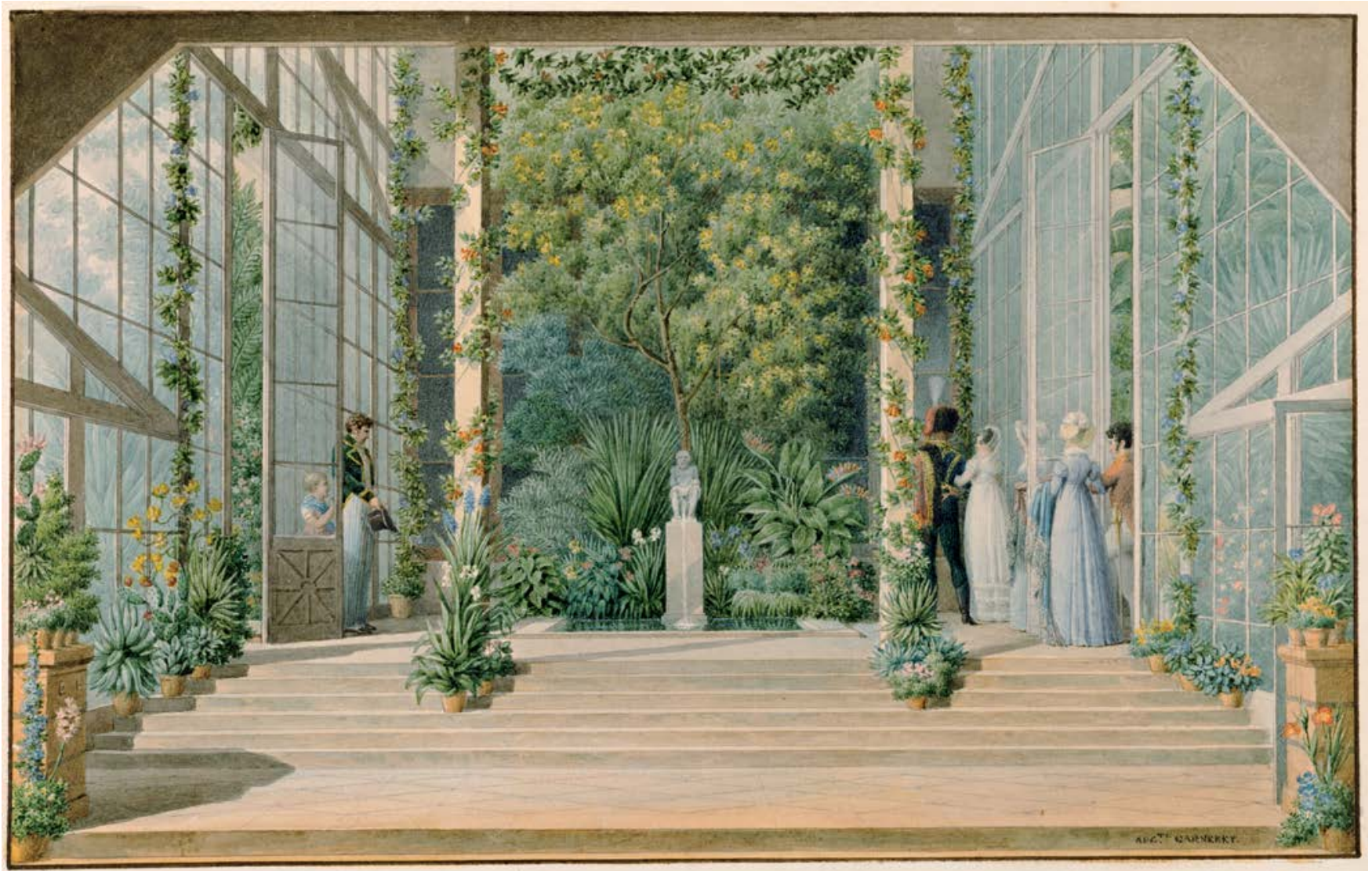

Fig. 3. - Interior of the Grande Serre Chaude. Watercolor, Auguste Garnerey (before 1824). [Photo: @ RMN-Grand Palais (Musée des châteaux de Malmaison et de Bois-Préau) / Daniel Arnaudet/Jean Schormans]

botanists (see Appendix II and nomenclatural chapter). The Michaux collections are mostly deposited at $\mathrm{P}$, notably in the Achille Richard (1794-1852) herbarium now in the general herbarium. The collections that related to his journey to North America published in Flora Boreali-Americana are part of the historical herbarium P-MICH. Plants from South Africa and the Cape region came notably from the D'Entrecasteaux Expedition. The Bruguière and Olivier journey to Persia (BERnARD, 1997) resulted in plants from Western Asia. Material collected by Poiteau and Anselme Riedlé (1765-1801) came from the West Indies. In 1796-1798 Riedlé travelled with Baudin on board the Belle-Angélique, later they became friends and Riedlé took part in the Baudin Expedition, dying in Timor on the way to Australia (see Bonnemains, 2000). Several collections of Riedlé have been legated to Baudin and are labelled as "Baudin herbarium" in $\mathrm{P}$ (they are here considered as Riedlé collections, see Jatropha hernandiifolia Vent. for an example, under $\mathrm{n}^{\circ} 36$ ).

We present a list of the 343 names dealt with by Ventenat in the Appendix II. Out of these 343 names, only 83 had been published before by other authors. Among the 259 names newly published by Ventenat, 25 represent new combinations, one can be considered as a new name [nom. nov.], nine are illegitimate names [nom. illeg.] (i.e. later honomyms), 26 are invalid names [nom. inval.] (i.e. 6 superfluous combinations and 20 superfluous names).

In total 208 names were validly published (incl. 9 later homonyms) by Ventenat in his three flower books, all these names are binomials except the name of the variety Andromeda calyculata var. anomala Vent. The list of these 208 names is presented in the Appendix II with their respective typification. Of these, 67 species names are still accepted today and a total of 52 further names are basionyms of names currently accepted in other genera.

The aim of this project was primarily to bring Ventenat's remarkable legacy to light. However, it is obvious that further isotypes or isolectoypes will be found in the future. We are conscious that further names will possibly need lectotypification in order to clarify previous typification cited in the literature. We hope that botanists will be more cautious in lectotypifing Ventenat's names in the future and carefully take the historical context into consideration. 


\section{Lectotypifications and miscellaneous notes}

\section{Achillea aspleniifolia Vent., Descr. P1. Nouv.: tab. 95.1802.}

Lectotypus (designated here): [UNITED STATES]: Hort. Cels, Ventenat s.n. (G [G00341485]!).

\section{$=$ Achillea millefolium $\mathrm{L}$.}

Notes. - Two different collections have been located in Ventenat's herbarium at $\mathrm{G}$. The plant collected by Michaux from his travel to North America (G [G00341484]) and the plant cultivated in Cels's garden. The latter is designated here as the lectotype as it is more complete and clearly served primarily for the description of Achillea aspleniifolia. No specimen has been located at $\mathrm{P}$.

\section{Alyssum mutabile Vent., Descr. P1. Nouv.: tab. 85.1802.}

$\equiv$ Berteroa mutabilis (Vent.) DC.

Lectotypus (designated here) : [Western Asia. "Levant"]: Hort. Cels, Ventenat s.n. (G [G00341571]!; isolecto-: G [G00341570]!).

Notes. - Two specimens of a single gathering have been located in Ventenat's herbarium in $G$ representing the plant cultivated in Cels's garden. The more complete collection is designated here as the lectotype.

\section{Anagallis fruticosa Vent., Choix P1.: tab. 14. 1803.}

Lectotypus (designated here): Morocco: Mogador [Essaouira], Broussonet s.n. (G [G00341554]!; isolecto- : B-W [B-W 03542-01 0]!, G-DC [G00138354]!).

\section{$=$ Anagallis monelli $\mathrm{L}$.}

Notes. - Three collections of a single gathering have been located. It represents the specimen collected by Broussonet in Mogador [now Essaouira], Morocco. We know that Delessert and Candolle exchanged herbarium specimens. The Broussonet collection in Ventenat's herbarium is therefore designated here as the lectotype.

4. Anamenia coriacea Vent., Jard. Malmaison 1: tab. 22. 1803.

Lectotypus (designated by Rasmussen, 1979: 27): [SoUTH AFrICA] : Hort. Malmaison, Ventenat s.n. (P-JU $\mathrm{n}^{\circ} 10574$ [P00667188]!; isolecto- : G [G00406216]!, G-DC [G00144870]!).

= Anemone vesicatoria (L. f.) Prantl

Notes. - Rasmussen (1979: 27) designated a lectotype at P-JU for Anemone coriacea now accepted under the name A. vesicatoria. The collection held at $\mathrm{P}-\mathrm{JU}$ is clearly a duplicate of the one at $\mathrm{G}$, both representing the same gathering from the plant cultivated at Malmaison with Ventenat's handwriting. Rasmussen (1979)'s lectotypification on a specimen at P-JU is unfortunate, but has priority. The $G$ specimens (in $G$ and $\mathrm{G}-\mathrm{DC}$ ) are considered here as isolectotypes.

\section{Ancistrum repens Vent., Descr. Pl. Nouv.: tab. 6. 1800.}

Lectotypus (designated here): [PERU]: "individu de pleine terre”, Hort. Cels, Ventenat s.n. (G [G00341457]!).

= Acaena ovalifolia Ruiz \& Pav.

Notes. - Two specimens are represented in Ventenat's herbarium that clearly represent two gatherings from Cels's garden. One collection is from the open ground ("individu de pleine terre") and the other from the orangery ("individu d'Orangerie") (G [G00341456]). We designate the first specimen as the lectotype as it better represents the species in the wild, despite the fact that the second specimen from the orangery was very likely the one to have been used for the plate. The specimen in the centre of the sheet $\mathrm{n}^{\circ} 14214$ in P-JU [P00667169] is from Cels's garden but no information of its exact provenance is given. It may represent an isolectotype.

6. Andromeda cassinefolia Vent., Descr. P1. Nouv.: tab. 60.1801.

Lectotypus (designated here) : [UNITED STATES] : Hort. Cels, Ventenat s.n. (G [G00341453]!).

$=$ Zenobia pulverulenta $(\mathrm{W}$. Bartram ex Willd.) Pollard

Notes. - In 1801, Ventenat validated in Descriptions the name Andromeda cassinefolia based on a specimen from material cultivated in Cels's garden [G00341453] designated here as the lectotype. In the second volume of Jardin de Malmaison (under tab. 79 published in 1804), Ventenat treated this taxon under the name $A$. cassinefolia var. nuda, a nom. nud. This taxon was illustrated by Redouté based on a second collection [G00408075] that is still extant in Ventenat's herbarium. We consider the second collection as an element of original material of $A$. cassinefolia because Ventenat in 1801 already discussed the variability of his new taxon and the second collection cited in 1804 was very likely already in his possession in 1801 .

7. Antirrbinum bipartitum Vent., Descr. P1. Nouv.: tab. 82.1802.

= Linaria bipartita (Vent.) Willd.

Lectotypus (first step designated by VIANO, 1978: 79; second step designated here): [Morroco]: Hort. Cels, Ventenat s.n. (G [G00190702]!; isolecto-: G [G00190703]!).

Notes. - Viano (1978: 79) in his revision of the genus Linaria sect. Versicolores (Benth.) Wettst. in the Mediterranean basin cited a "herb. Ventenat" specimen at $\mathrm{G}$ as type. 
This implicit lectotypification needs a second step designation, as two collections exist in the Ventenat herbarium. We designate the more complete sheet as the lectotype. Four sheets of original material from Broussonet from Morocco are held in G-DC [G00478868] and one more in the Willdenow herbarium in B-W [B-W 11278-01 0].

8. Apium prostratum Vent., Jard. Malmaison 2: tab. 81. 1804-1805.

Lectotypus (designated here) : [AusTRALIA]: Hort. Malmaison, Ventenat s.n. (G [G00359756]!; isolecto-: G-DC [G00478844]!).

= Apium prostratum Labill., Voy. Rech. Pérouse 1: 141. 1800 [nom. nud.], Nov. Holl. P1. 1: 76, tab. 103. 1805 [nom. illeg.]. Typus: Australia. Tasmania: Van Diemen, La Billardière s.n. (holo-: FI-W [FI016964] image seen; iso- : B-W [B-W 5989-01 0]!, G-DC [G00478846]!, FI-W [FI016965] image seen, P [P00834725, P00834726]!, P-JU n 10157 [P00307178]!).

Notes. - The seeds of this new species were received from Hamelin who took part in the Baudin Expedition to the Southern Territories (see introduction). A single gathering exists in Ventenat's herbarium at $\mathrm{G}$, a plant cultivated in Malmaison with a fragment in G-DC. The collection in Ventenat's herbarium is designated here as the lectotype. Ventenat in Jardin de Malmaison (1804-1805: tab. 81) wrote in the note following the species description that his new species seems to be the same [“...paroit..."] as the one mentioned by LA BILLARDIÈRe (1800:141). Apium prostratum Labill. is a nom. nud. in 1800 but was validly published in September 1805 by LA Billardière (1804-1805: 76, tab. 103). However, Ventenat's name had been published between December 1804 and January 1805 (STEARN, 1939) and antedates La Billardière's. Both names are independent and not based on the same types. SноRт (1979: 217) combined both names and mentioned a type in $\mathrm{P}$ as the holotype and an isotype in G-DC. In the latter herbarium, original material of both names are present. A holotype and two isotypes of $\mathrm{La}$ Billardière's later homonym are present respectively in FI-W, and in B-W and P-JU.

\section{Ardisia crenulata Vent., Choix P1.: tab. 5. 1803.}

= Parathesis crenulata (Vent.) Hook. f. ex Hemsl.

Typus : Dominican Republic / Haiti : "St. Domingo", Poiteau s.n. (holo-: G [G00341511]; iso- : G [G00341669]!, P-JU n ${ }^{\circ} 7315+B$ [P00671356]!).

Notes. - Howard (1989: 43) designated plate 5 [tab. 5] in Choix in 1803 as the lectotype. The finding of its holotype, Poiteau s.n., the only extant collection in the Ventenat herbarium, supersedes this lectotypification. Two duplicates of
Poiteau's collection have been located in the general herbarium at $\mathrm{G}$ and and in P-JU herbarium respectively and are here considered as isotypes.

A specimen annotated by Carl Ludwig Willdenow "Ardisia crenula" [sic] and by Dietrich Friedrich Karl von Schlechtendal "Seidel Paris W [illdenow]" [B-W 044901-01 0] was probably collected by the gardener Jacob Friedrich Seidel, albeit almost certainly after 1803 and therefore illegible for typification. The latter is reported to have worked from 1810 to c. 1812 in the "Jardin des Plantes" in Paris (Riedel \& Riedel, 2010).

10. Bejaria racemosa Vent., Descr. P1. Nouv.: tab. 51. 1801.

Lectotypus (designated by Clemants, $1995:$ 71): UNITED STATES. Florida: Michaux s.n. (G [G00342248]!; isolecto- : P [P02441846, P02441849]!, P-MICH [P00667179, P00667182, P00667183]!).

Notes. - The name Bejaria racemosa was validated on the basis of a plant in Cels's garden raised from seeds brought back by Bosc from a botanical garden in Charles-Town [Charleston, Boston], possibly the garden founded after 1786 by Michaux "ten miles from Charlestown" (Ramsay, 1858). Ventenat also mentioned in the protologue that Michaux discovered the plant in Florida. No cultivated specimen exists in Ventenat's herbarium but a single specimen from Florida, i.e. the Michaux collection, is extant. This collection has been designated as the lectotype by Clemants (1995: 71). A collection from Cels's garden exists in the G-DC herbarium [G00454403] and is here considered as original material. Duplicates of Michaux collections in $\mathrm{P}$ and $\mathrm{P}-\mathrm{MICH}$ are considered as isolectotypes. Another collection in G-DC [G00454405] represents a cultivated plant from Malmaison but it seems that it was collected after the validation of the name in 1801 and is here not considered as original material.

Michaux (1803) published the name B. paniculata Michx., [nom. illeg.] [non B. paniculata Cels ex Dum. Cours.], a homotypic synonym of $B$. racemosa based on the same gathering as Ventenat. Ventenat in Choix (1808: sub tab. 52) already considered these names as synonyms and wrote: "Lauteur de la Flore de l'Amérique Septentrionale [i.e. Michaux] a cru devoir substituer au nom spécifique de racemosa celui de paniculata." ["The author of the Flore de l'Amérique Septentrionale [i.e. Michaux] felt that he had to substitute the specific name racemosa with paniculata."]

11. Caladium nymphaeifolium Vent. in Mag. Encycl. 4: 471. 1801 [cited in Descr. P1. Nouv.: sub tab. 30. 1801].

Lectotypus (designated here): [INDONESIA]: "Wali Ila", (Rheede, Hort. Malab. 9: tab. 22. 1689).

$=$ Colocasia esculenta $(\mathrm{L}$.) Schott 


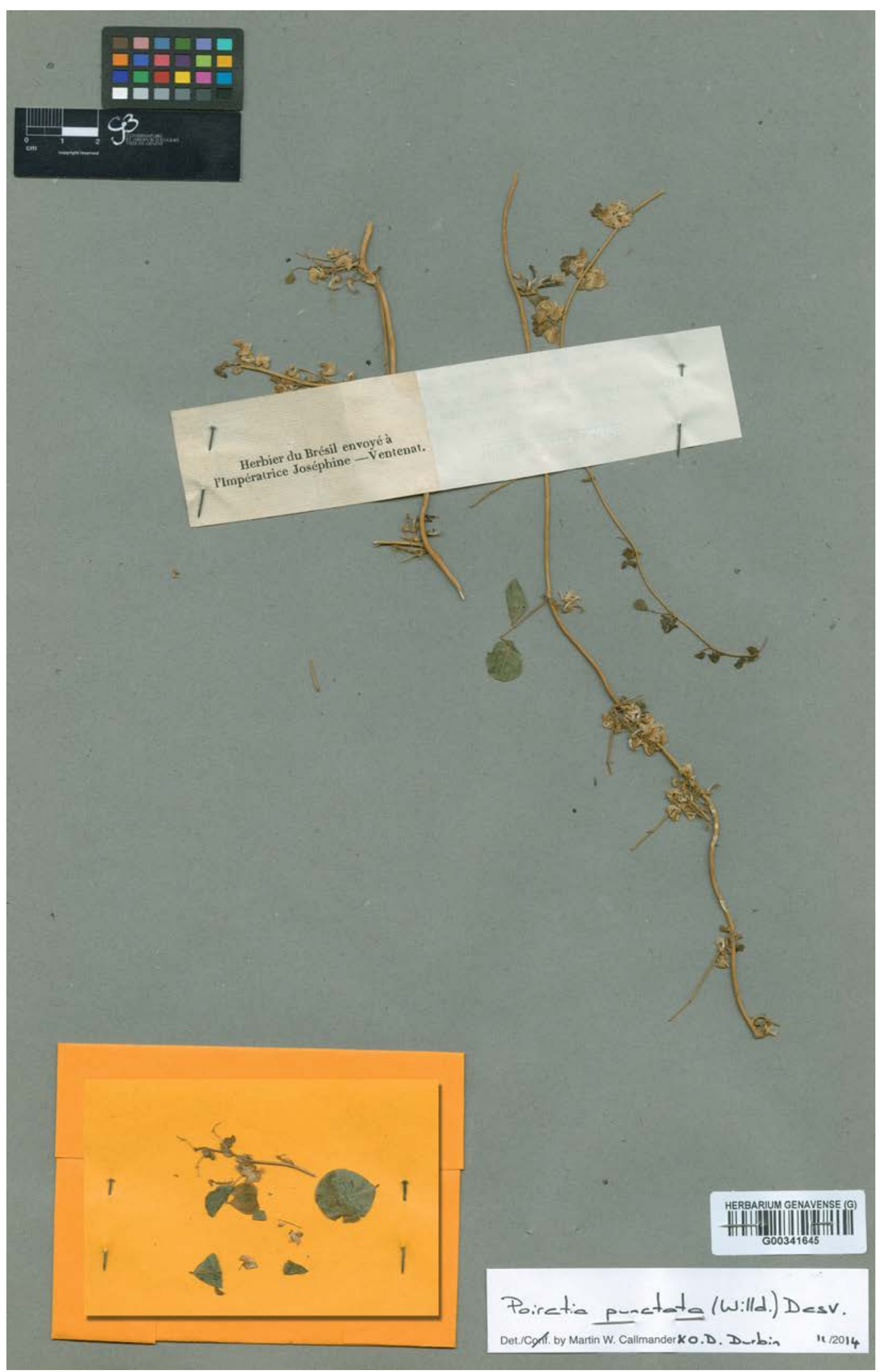

Fig. 4. - Poiretia punctata (Willd.) Desv. Specimen of a collection from Brazil sent by Ventenat to the Empress Joséphine, kept at G. 
Notes. - Despite a search for original material of this species at $\mathrm{G}$ and $\mathrm{P}$, no collection has been located. The name Caladium nymphaeifolium was validated by Ventenat in Descriptions in 1801 in the text below the description of Caladium bicolor (Ait.) Vent. with no illustration but with a clear reference to Hortus Malabricus vol. 9 (Rheede, 1689): "une espèce que j'ai trouvée dans l'herbier Jussieu, qui est figurée dans le IXème vol. de l'Hort. Malabar., t. 22, et à laquelle j'ai donné le nom de nymphaeifolium." "a species that I found in the Jussieu herbarium, which is illustrated in the ninth vol. of the Hort. Malabar., t. 22, and to which I gave the name of nymphaeifolium."]. Until original material is located, we designate tab. 22 in RHEEDE (1689) as the lectotype.

12. Calendula chrysanthemifolia Vent., Jard. Malmaison 1: tab. 56. 1804.

\section{$\equiv$ Dimorphotheca chrysanthemifolia (Vent.) DC.}

Lectotypus (designated here): [SouTH AFrICA]: Hort. Malmaison, Ventenat s.n. (G [G00341480]!; isolecto-: G [G00341479]!).

Notes. - Two specimens of a single gathering have been located in Ventenat's herbarium at G. It represents the plant cultivated in Empress Joséphine's garden. The more complete collection is designated here as the lectotype.

13. Casearia ulmifolia Vahl ex Vent., Choix P1.: sub tab. 46. 1808.

Lectotypus (first step designated by Sleumer, 1980 : 324 ; second step designated here): TRINIDAD : 1778, Ryan 20 (C [C10012565] image seen; isolecto-: BM [BM000624343] image seen, BR [BR0000005104826] image seen, C [C10012566, C10012567, C10012568, C10012569, C10012570, C10012571] images seen, G [G00364133]!, L [L0010781] image seen, P-JU n ${ }^{\circ} 16215$ [P00678826]!).

Notes. - Ventenat validated Vahl's name by publishing a few comparative leaf characters: "[bords de feuille] finement dentés en scie". SLEUMER (1980:324) correctly considered the type as being held at $\mathrm{C}$. His implicit lectotypification needs a second step designation as seven sheets exist at $\mathrm{C}$. In their revision of the Casearia ulmifolia complex, Marquete \& Mansano (2012 : 201) failed to properly designate a single sheet at C as the lectotype. We designate the most complete sheet in $\mathrm{C}$ as the lectotype. Several isolectotypes are known, among them one in Ventenat's herbarium. We are not in agreement with previous authors (Sleumer, 1980; Marquete \& Mansano, 2012) and do not consider the collection in G-DC [G00476917] as elements of original material.
14. Casuarina distyla Vent., Descr. P1. Nouv.: tab. 62.1802. $\equiv$ Allocasuarina distyla (Vent.) L.A.S. Johnson

Typus: [Australia]: Hort. Cels, Ventenat s.n. (holo-: G [G00341454]!; iso-: NSW [NSW62357] image seen).

Notes. - Johnson (1992: 75) transferred Casuarina distyla to his new genus Allocasuarina L.A.S. Johnson. The author designated the collection at $\mathrm{G}$ from Cels's garden as the lectotype. Only one collection is extant in Ventenat's herbarium and should therefore be considered as the holotype. A clastotype is present in NSW and should be considered as the isotype. The two other collections mentioned by JoHnson (1992: 75) in K [K000872501] (Herb. Forsyth. purchased 1835) and P [P00735055] (“donné par Bonpland en 1835”) have been very likely collected later in Cels's garden and are here not considered as isotypes. The provenance of the plant has been recorded as "Cap de Diemen" in Tasmania but is clearly from New South Wales (Johnson, 1992).

15. Celsia lanceolata Vent., Descr. P1. Nouv.: tab. 27.1801.

Lectotypus (designated here): [IRAd: Hort. Cels, Ventenat s.n. (G [G00341500]!; isolecto-: G-BOIS [G00330749]!).

$=$ Verbascum assurense Bornm. \& Hand.-Mazz.

Notes. - The name Celsia lanceolata has been validated in Descriptions in 1801 based on a Bruguière and Olivier collection from Iraq (between Mosul and Baghdad) and cultivated in Cels's garden. The specimen in Ventenat's herbarium from Cels's garden is designated here as the lectotype with a duplicate in G-BOIS. Four specimens collected between Mosul and Baghdad by Bruguière and Olivier have been located in G-BOIS [G00330748, G00330750] and P [P03287379, P03287380]. They are here considered as elements of original material. HubER-Morath (1981: 25) in his revision of Verbascum L. for Flora Iranica did not cite any type for Celsia lanceolata.

16. Cheiranthus linearis Vent., Jard. Malmaison 2: sub tab. 83. 1804 [nom. illeg.] [non C. linearis Forssk.].

Lectotypus (designated here): [SPAIN. Canary Islands, Tenerife]: Hort. Cels, Ventenat s.n. (G [G00341602]!).

= Erysimum semperflorens (Schousb.) Wettst.

Notes. - Two specimens are present in Ventenat's herbarium that clearly represent two gatherings. One of the collections came from Cels's garden and the other from Malmaison [G00341604]. The first gathering is a better specimen and is here designated as the lectotype. Other collections exist from the material brought back by Broussonet while he served as Commissioner of commercial relations in Tenerife in the early $19^{\text {th }}$ century (CANDOLLE, 1809). Those collections are here considered as elements of original material (G-DC [G00149541]). 
17. Cheiranthus longifolius Vent., Jard. Malmaison 2: tab. 83. 1804.

Lectotypus (designated here): [SPAIN. Canary Islands, Tenerife]: Hort. Cels, Ventenat s.n. (G [G00341510]!; isolecto-: G-DC [G00149563]!).

\section{= Erysimum heritieri Kuntze}

Notes. - Specimens present in Ventenat's herbarium clearly represent two gatherings. One of the collections came from Cels's garden and the other is material brought back by Broussonet ( $\mathrm{G}$ [G00341595], with a duplicate in G-DC [G00149716]). The gathering from Cels's garden is a better specimen and is here designated as the lectotype.

18. Chrysanthemum praealtum Vent., Descr. P1. Nouv.: tab. 43. 1801.

Lectotypus (designated here) : Iran : Mt. Albourg, Bruguière E' Olivier s.n. (G [G00341493]!; probable isolecto- : G [G00341494]!).

= Tanacetum parthenium (L.) Sch. Bip.

Notes. - Two gatherings have been located for this species: the specimen collected by Bruguière and Olivier in Iran in Ventenat's herbarium and the cultivated specimen from Cels's garden in G-DC [G00450767]. A second collection in Ventenat's herbarium has no information on its origin. The Bruguière and Olivier collection is here designated as the lectotype. A second collection at G [G00341494] is considered as a probable isolectotype but could also represent a Cels's garden collection and should then be considered as a duplicate of the material in G-DC.

19. Clerodendrum viscosum Vent., Jard. Malmaison 1: tab. 25. 1803.

Lectotypus (designated here): [INDONESIA. Java]: Hort. Cels, Ventenat s.n. (G [G00341557]!).

\section{= Clerodendrum infortunatum $\mathrm{L}$.}

Notes. - When validating the name Clerodendrum viscosum Ventenat specifically wrote that his species concept excluded what was named $C$. infortunatum L. in P-JU. Two collections exist in Ventenat's herbarium. A cultivated specimen from Cels's garden and a second with two leaves with a label "Dedit Juss., exclusis syn. et figuris Rhumphii et Burmanii" and two additional leaves with a blank label attached. The two leaves "Dedit Juss." clearly represent what Ventenat called $C$. infortunatum and should not be considered as type material of his C. viscosum. No further material has been located at P-JU. In spite of any additional information regarding the two leaves present on the sheet we prefer to consider this specimen [G00341644] as original material whereas the cultivated plant from Cels's garden is designated here as the lectotype.

20. Colletia ephedra Vent., Descr. P1. Nouv.: sub tab. 92.1803.

$\equiv$ Retanilla ephedra (Vent.) Brongn.

Lectotypus (first step designated by TorTosA, 1992: 235 ; second step designated here): CHILE: sine loc., Dombey s.n. (P [P01818929]!; isolecto-: G [G00341460, G00341672]!, G-DC [G00476003]!, P [P01818930, P01818931]!, P-JU $\mathrm{n}^{\circ} 16153$ [P00678779]!).

= Colletia obcordata Vent., Descr. P1. Nouv.: tab. 92. 1803. Lectotypus (designated here): [CHILE]: Hort. Cels, Ventenat s.n. (G [G00341459]! ; isolecto- : G [G00341458]!, G-DC [G00476011]!, P-JU n 16157 [P00667163]!)

Notes. - Ventenat in Descriptions (1803: sub tab. 92) validated the name Colletia ephedra based on a Joseph Dombey (1742-1794) specimen from Peru. Dombey was a French explorer who collected in Chile, Peru and Brazil (Stafleu \& Cowan, 1986). Tortosa (1992: 235) designated an holotype specimen at $\mathrm{P}$. His implicit lectotypification needs a second step designation as three sheets exist at P. We designate here the most complete sheet at $\mathrm{P}$ as the lectotype. Several duplicates have been found. TorTosA (1992: 235) corrected the origin of the material collected by Dombey as from Chile and not Peru. Colletia ephedra has been illustrated in Choix tab. 16 in late 1803 or early 1804.

Two specimens of a single gathering of $C$. obcordata have been located in Ventenat's herbarium at G. It represents the plant cultivated in Cels's garden. The most complete collection is designated here as the lectotype. TorTosA (1992: 235) designated the type specimen at $\mathrm{P}$ but no collection has been located at $\mathrm{P}$ in the general collection.

21. Correa revoluta Vent., Jard. Malmaison 1: sub tab. 13.1803. = Correa reflexa (Labill.) Vent.

Typus: Australia : sine loc., Neé s.n. (holo-: G [G00439910]!; iso- : MA-305905!, MA-305906!).

Notes. - The name Correa revoluta was validated with a short latin diagnosis ending in the note: "Specimen a Dom. Cavanilles datum". The only collection we found at $\mathrm{G}$ bears a label in Cavanilles's handwriting but provides no details on the collector. A visit at MA revealed that two duplicates exist in the general collection with Cavanilles's handwriting: "Mazentoxerum reflexum? Correa Smith", which is the same text as on the label in Ventenat's herbarium. This collection is in fact from Luis Neé (1734-1803), who was one of the two botanists besides Thaddäus 


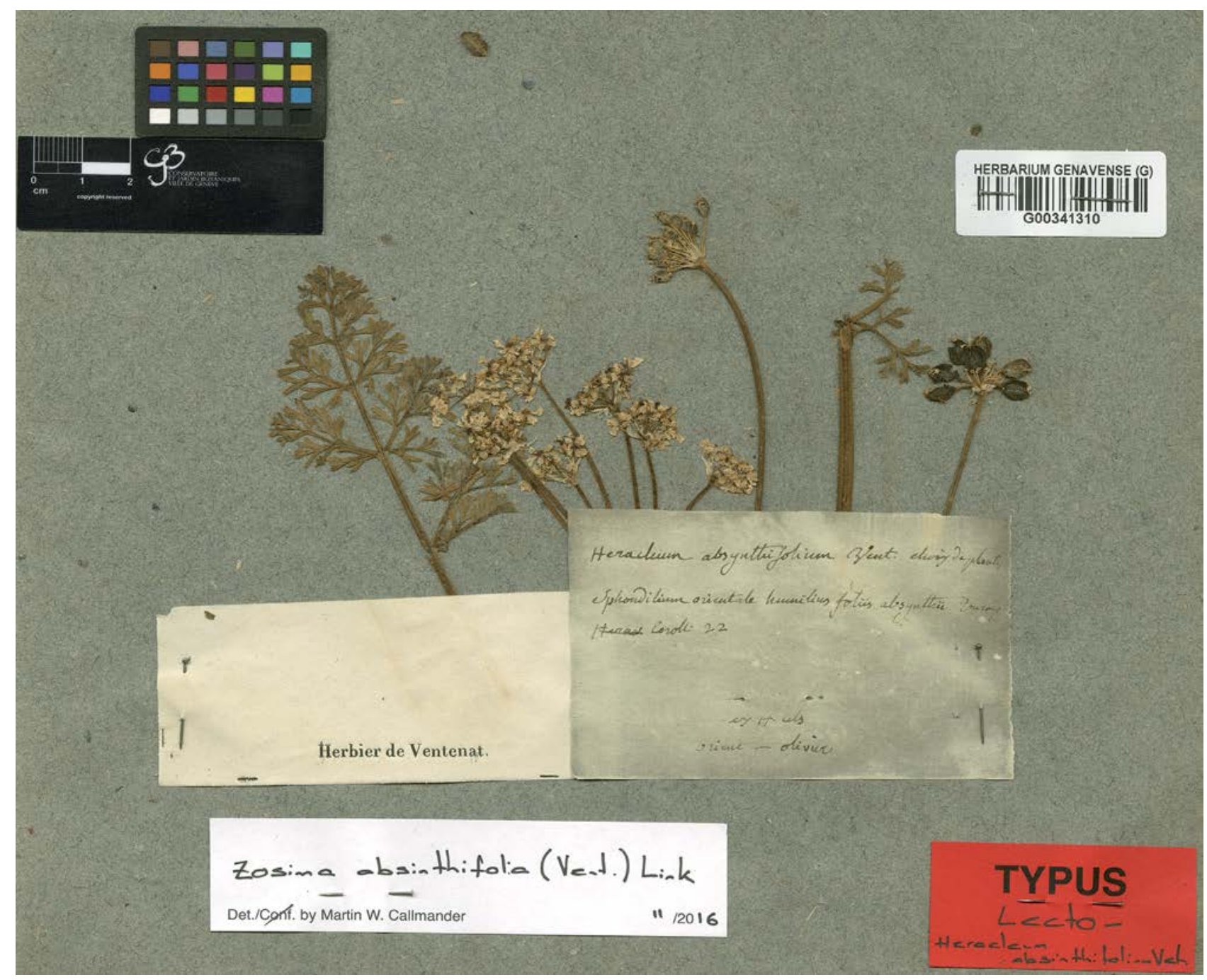

Fig. 5. - Ventenat's handwriting and typical footer labels at G on the lectotype of Heracleum absynthifolium Vent.

Haenke (1761-1817) who took part in the Malaspina Expedition (1789-1794) (MuÑoz Garmendia, 2001) which aimed to establish a rational and coherent description of the possessions of the Spanish monarchy. The plants collected by Neé during this expedition served for the descriptions of new species by several botanists, among them Cavanilles and Candolle (Galera, 2016).

22. Dalea purpurea Vent., Descr. P1. Nouv.: tab. 40. 1801.

Lectotypus (designated here): UNITED STATES. Illinois : Michaux s.n. (G [G00341562]!; isolecto-: P [P02141637, $\mathrm{P} 02141638]$ !, $\mathrm{P}-\mathrm{MICH}$ [P00667210 in part]!).

Notes. - In the Ventenat herbarium, two specimens have been found. One is clearly the one sent by Michaux from Illinois and the second is a sterile collection cultivated in Cels's garden [G00341561]. We choose to designate as the lectotype the Michaux s.n. collection as it is fertile and better represents the morphology of Dalea purpurea. Michaux collections determined as Petalostemon violaceus Michx. and kept in $\mathrm{P}$ and $\mathrm{P}-\mathrm{MICH}$ are considered as isolectotypes as they do represent the same collection that Ventenat received from Illinois which would be described by him as Dalea purpurea. In P-MICH [P00667210] only the collections on the far left and far right are type material.

23. Dianthus monadelphus Vent., Descr. P1. Nouv. : tab. 39. 1801.

Lectotypus (designated here) : [SYRIA] : (Ventenat, Descr. P1. Nouv.: tab. 39. 1801).

Notes. - No trustful collection of this species has been located. Among the undetermined specimen of Dianthus L. kept in $\mathrm{P}$ and originating from Asia, we found three 


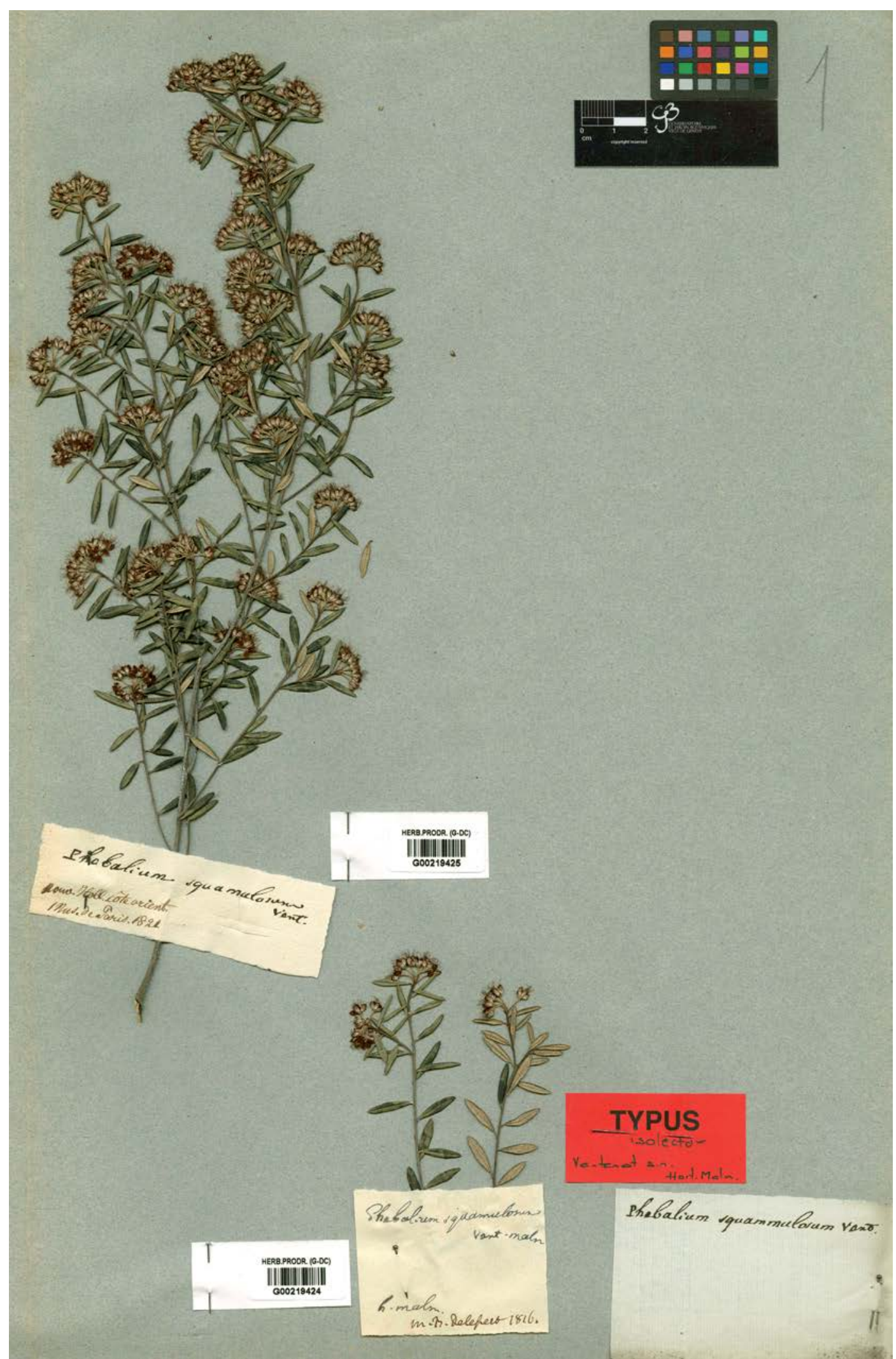

Fig. 6. - Isolectotype of Phebalium squamulosum Vent. in G-DC showing the mention "M. B. Delessert 1816" (see p. 94). 
collections gathered by Bruguière and Olivier [P04982230, P04982231, P04982239]. These collections may represent type material but we prefer to designate the plate tab. 39 as the lectotype until trustful type material can be assigned to this species.

24. Diosma cerefolia Vent., Jard. Malmaison 2: tab. 83. 1805.

= Agathosma cerefolia (Vent.) Bartl. \& H.L.Wendl.

Lectotypus (designated here): [SouTH AfrICA]: Hort. Malmaison, Ventenat s.n. (G [G00006331]!; isolecto- : G-DC [G00219310]!).

Notes. - Two specimens of a single gathering have been located: one in Ventenat's herbarium at $\mathrm{G}$ and a fragment in G-DC with the mention "M. B. Delessert 1816". The later was therefore part of Ventenat's herbarium before Delessert gave this fragment to Candolle (see introduction). The collection in Ventenat's herbarium is designated here as the lectotype.

Another collection in G-DC [G00219309] originating from Malmaison has been collected after the validation of the name Diosma cerefolia and cannot be considered as original material.

25. Echium thyrsoideum Juss. ex Vent., Jard. Malmaison 2: sub tab. 97. 1805.

Lectotypus (designated here): EUROPE: Anon. s.n. (P-JU $\mathrm{n}^{\circ} 6609$ [P00667187]!).

= Echium maculatum $\mathrm{L}$.

Notes. - Ventenat clearly referred to a plant that was communicated to him by Jussieu. No material was found at $G$ and the collection in the P-JU herbarium is designated here as the lectotype.

26. Epilobium tomentosum Vent., Descr. P1. Nouv.: tab. 90. 1802.

Lectotypus (designated here): [IRAN]: Hort. Cels, Ventenat s.n. (G [G00406205]!; probable isolecto- : G-DC [G00654566]!).

\section{= Epilobium hirsutum $\mathrm{L}$.}

Notes. - Two specimens of a single gathering have been located in Ventenat's herbarium at G. It represents the plant cultivated in Cels's garden. A collection in G-DC with the mention "h. Cels" may represents original material. We therefore prefer to designate here the lectotype on the unique collection extant in Ventenat's herbarium.
27. Eupatorium ayapana Vent., Jard. Malmaison 1: tab. 3.1803.

Lectotypus (designated here): [BRAZIL]: Hort. Malmaison, Ventenat s.n. (G [G00341565 right hand specimen]!; probable isolecto- : G-DC [G00495105]!).

= Ayapana triplinervis (Vahl) R.M. King \& H. Rob.

Notes. - The only sheet in the Ventenat herbarium consists of two gatherings. The plant cultivated at Malmaison and a Michaux collection from Mauritius [G00341565 left hand specimen] where the plant had for long been cultivated. We designate here as the lectotype the specimen from Malmaison as it is the most complete material. A probable isolectotype exists in G-DC.

28. Heracleum absinthifolium Vent., Choix P1.: tab. 7. 1803.

$\equiv$ Zosima absinthifolia (Vent.) Link

Lectotypus (designated here): [TURKEY]: Hort. Cels, Ventenat s.n. (G [G00341310]!) (Fig. 5).

Notes. - When validating the name Heracleum absinthifolium, Ventenat referred to "Sphondylium orientale humulius, foliis absinthii”, a pre-linnean name coined by Joseph Pitton de Tournefort (1656-1708) in the herbaria of Vaillant and Jussieu. A specimen has been located in Herb. Vaillant and is here considered as original material [P00662760]. Further collections of Bruguière and Olivier from Turkey have been located in G-DC [G00477269]. The only collection from Cels's garden in Ventenat's herbarium is designated here as the lectotype. Recent revisions of the genus Zosima Hoffm. (Alava, 1987 ; Menemen \& Jury, 2001) cited as type material a collection at $G$ with the locality information taken from Ventenat; however no collection exists with this locality.

29. Hypericum dolabriforme Vent., Descr. P1. Nouv.: tab. 45. 1801.

Lectotypus (designated by Robson, 1996: 123) : UNITED STATES. Kentucky: Michaux s.n. (G [G00341526]!; isolecto-: P [P01901389, P02442087, P02442088, P02442089, P02442090]!, P-JU n 11841 [P00667214]!, P-MICH [P00667207, P00667217]!).

Notes. - Hypericum dolabriforme is endemic to the southeastern regions of the United States (from southern Indiana to northwestern Georgia) (Robson, 1996). Only a single specimen exists in Ventenat's herbarium, i.e. the Michaux collection from Kentucky. Michaux (1803: 81) validated the name $H$. procumbens Michx. [nom. illeg.] [non Desf. ex Willd.] based on the same material. Roвson 


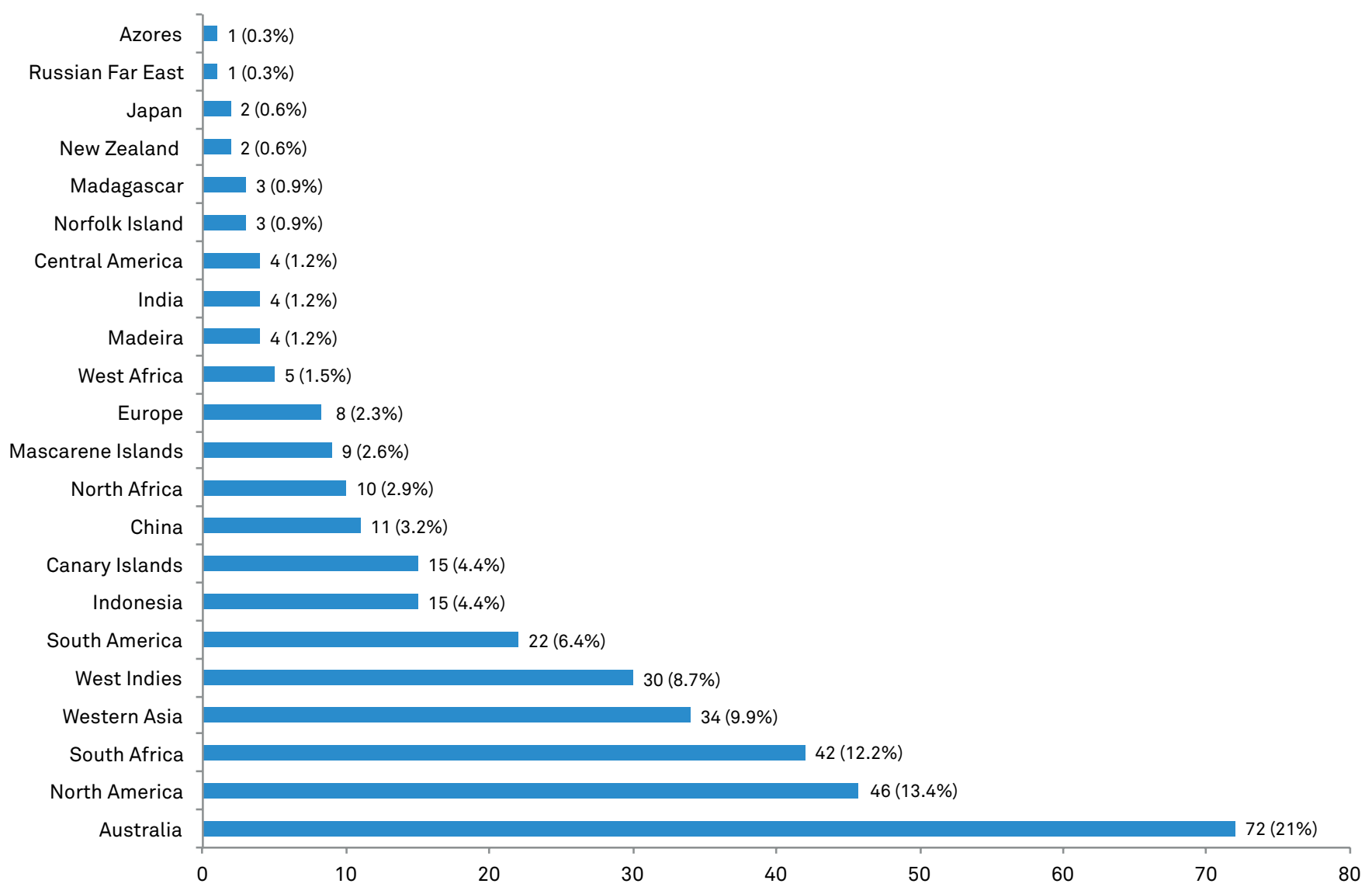

Fig. 7. - Geographical origins of the 343 taxa cited by Ventenat between 1800 and 1808 in Descriptions, Choix and Jardin de Malmaison. Geographical regions refer to Appendix II.

(1996: 123) implicitly lectotypied Ventenat's name by referring to the unique specimen at $\mathrm{G}$. A collection of this species given by Ventenat to Jussieu from Cels's garden in 1803 is here considered as original material (P-JU n ${ }^{\circ}$ 11832 [P00667211]).

30. Illicium parviflorum Michx. ex Vent., Tabl. Règn. Vég. 3 : 71. 1799 [cited in Descr. P1. Nouv.: tab. 22. 1801].

Lectotypus (designated here): UNITED STATES. Florida: Lake George, Michaux s.n. (G [G00341506]!; isolecto-: P [P01656597 upper specimen]!, P-MICH [P00667213]!).

Notes. - Lin (2000:177) in his revision of the genus cited the type of the name of this species as: "U.S. Lake George, details unkown". This cannot be accepted as an implicit lectotypification. Two specimens exist at $\mathrm{G}$ : the cultivated specimen from Cels's garden [G00341505] and the collection from Michaux. The latter is designated as the lectotype as it is more complete and two isolectotypes have been located in the $\mathrm{P}$ and in $\mathrm{P}-\mathrm{MICH}$ herbaria respectively.
A specimen annotated in Ventenat's hand "Illicium parviflorum H. Cels t. 22" and in D. F. K. v. Schlechtendal's hand "Ventenat. W [illdenow]" [B-W 10382-01 0] is also available for interpretation of this name.

31. Inga filipes Vent. in Mém. Cl. Sci. Math. Inst. Natl. France 8: 6. 1807 [also in Choix. Pl.: tab. 38. 1807].

$\equiv$ Cojoba filipes (Vent.) Barneby \& J.W. Grimes

Lectotypus (designated here) : DoMiniCAN REPUbLIC / Haiti: "St. Domingo", Poiteau s.n. (G [G00341450]!; isolecto-: G [G00341677]!, G-DC [G00652190]!).

Notes. - Two specimens of a single gathering have been located: one in Ventenat's herbarium at $G$ and a fragment in G-DC with the mention "M. B. Delessert 1816". The later was therefore part of Ventenat's herbarium before Delessert gave this fragment to Candolle (see introduction). The collection in Ventenat's herbarium is designated here as the lectotype. A Poiteau duplicate is also present in G [G00341677]. 
32. Inula gnaphalodes Vent., Descr. P1. Nouv.: tab. 75. 1802.

$\equiv$ Pulicaria gnaphalodes (Vent.) Boiss.

Lectotypus (designated here): [IRAN] : Anon. s.n. (G [G00341476 right-hand specimen]!).

Notes. - This species was described on the basis of material brought back by Bruguière and Olivier from Iran. Several collections have been located of this material at G-DC and P. A single collection exists in Ventenat's herbarium but with two gatherings. The left part represents the cultivated collection from Cels's garden and the right part a collection with, possibly, Desfointaines's handwriting. We have not been able to trace this collection in the historical nor general collections at P. LACK (1980:116) designated tab. 75 in Descriptions as the lectotype. The finding of original material supersedes this explicit lectotypification. We prefer to designate here the collection Anon. s.n. as the lectotype despite the fact that we neither know the collector nor the origin. This collection is a flowering specimen and possibly used for the preparation of the drawing. The cultivated collection from Cels's garden is sterile and is here considered as original material G [G00341476 left-hand specimen]. Other original material collected by Bruguière and Olivier documents the morphology of this plant in the wild (G-DC [G00468136], P [P02812002, P02812003, P02812004, P03295331]).

33. Ionidium buxifolium Vent., Jard. Malmaison 1: sub tab. 27. 1803.

\section{= Afrohybanthus buxifolius (Vent.) Flicker}

Lectotypus (designated here): MADAGASCAR : sine loc., Commerson s.n. (P-JU n ${ }^{\circ} 12784$ [P00667193]!; isolecto- : G [G00341436]!).

Notes. - Flicker \& Ballard (2015: 44) transferred Ionidium buxifolium to their new genus Afrobybanthus Flicker (Violaceae). The authors cited the collection at P-JU as the holotype. Ventenat in Jardin de Malmaison (1803: sub tab. 27) explicitly mentioned "ex Herb Juss". However, at G a very fragmented clastotype exists. We therefore considered that the collection in P-JU should be designated as the lectotype since it is a much better preserved collection and the specimen was used by Ventenat for the validation of the name Ionidium buxifolium.

34. Ionidium heterophyllum Vent., Jard. Malmaison 1: sub tab. 27. 1803.

Lectotypus (designated here) : China : sine loc., d'Incarville 109 (P-JU n 12788 [P00667186]!; isolecto- : $\mathrm{G}$ [G00341597]!).

$=$ Afrohybanthus enneaspermus (L.) Flicker
Notes. - Flicker \& Ballard (2015: 48) cited the collection at P-JU as the holotype. Ventenat in Jardin de Malmaison (1803: sub tab. 27) clearly mentioned "ex Herb Juss" and the collection deposited in his herbarium at $\mathrm{P}-\mathrm{JU}$ should be considered as the holotype. Nevertheless, as above under Ionidium buxifolium, the $\mathrm{G}$ collection is a very fragmented clastotype and the collection deposited at $\mathrm{P}-\mathrm{JU}$ is a much better preserved collection and was used by Ventenat for the description of Ionidium heterophyllum. The $\mathrm{P}-\mathrm{JU}$ collection is therefore designated as the lectotype but cannot be considered as the holotype as given by FLICKER \& BALLARD (2015).

35. Ionidium strictum Vent., Jard. Malmaison 1: sub tab. 27. 1803.

$\equiv$ Viola stricta (Vent.) Poir.

Lectotypus (designated here): DoMiniCAN REPUBLIC / Haiti: "St. Domingo", Poiteau s.n. (P-JU n 12799 [P00672092]!; isolecto- : G-DC [G00209948]!, P-JU $\mathrm{n}^{\circ} 12799$ [P00672093]!).

Notes. - No collection has been located at G. Two collections have been located at P-JU and one at G-DC. The more complete collection at $\mathrm{P}-\mathrm{JU}$ is designated here as the lectotype and the remaining collections are considered as isolectotypes.

36. Jatropha hernandiifolia Vent., Jard. Malmaison 1: sub tab. 52. 1804 .

Lectotypus (designated here): United States. Puerto Rico: sine loc., Riedlé s.n. (P [P04829499]!; isolecto- : P-JU $\mathrm{n}^{\circ} 16506$ [P00678913]!).

Notes. - Dehgan (2012: 145) cited a Poiteau s.n. collection as type collected in Santo Domingo [P04829428]. Ventenat in Jardin de Malmaison (1804: sub tab. 52) clearly stated that he has obtained this taxon from Riedlé in Puerto Rico while travelling on the Belle-Angélique to the West Indies and Porto Rico with his friend Baudin (see introduction).

No collection of Jatropha hernandiifolia exists at G but two collections have been found in P. On the collection Riedlé s.n. [P04829499] "graines $\mathrm{n}^{\circ} 131$ " has been written and this collection does represent the collection form which Ventenat obtained seeds. It is here designated as the lectotype. A Herb. Baudin collection in P-JU is considered as isolectotype because it also represents material gathered by Riedlé (see above).

37. Lantana nivea Vent., Jard. Malmaison 1: tab. 8. 1803.

Lectotypus (designated here) : [BRAZIL]: Hort. Malmaison, Ventenat s.n. (G [G00341488]!; isolecto- : G [G00341487]!). 
Notes. - Ventenat stated that he had received material of this plant from gardens in the East Indies but it seems clear that the plant originated in southern Brazil (SANDERs, 2006). The latter author did not locate the holotype and designated the colour copper engraving in Ventenat's Jardin de Malmaison (1803: tab. 8) as the lectotype and also designated as the epitype a plant cultivated in Paris held at C (Siebke s.n.). The finding of the type material in Ventenat's herbarium supersedes this lectotypification. Two collections exists in Ventenat's herbarium. The better preserved sheet is designated here as the lectotype.

38. Laserpitium triquetrum Vent., Descr. P1. Nouv.: tab. 97. 1803.

\section{$\equiv$ Heptaptera triquetra (Vent.) Tutin}

Lectotypus (designated here): [TURKEY]: Hort. Cels, Ventenat s.n. (G [G00341535]!).

Notes. - The plant cultivated by Cels originated from a Bruguière and Olivier collection from Turkey. The cultivated specimen from Cels in Ventenat's herbarium is designated as the lectotype as it represents the original material. Collections in G-BOIS [G00330753, G00330754] and P [P04274054] are considered here as original material. Herrnstadt \& Heyn (1971: 106) designated a type at $G$ and copied the locality given by Ventenat in Descriptions (1803: tab. 8): "Constantinople sur les bords du Canal". No Bruguière and Olivier collection exists with this locality (see Material and Methods chapter) and their potential implicit lectotypification is not accepted here. The G-BOIS collections have "voyage de Bruguière \& Olivier en Orient" even if Boissier (1872: 944) gave "Hab. in collibus ad Bosphorum proper Byzantium (Oliv.!)”.

39. Leptospermum triloculare Vent., Jard. Malmaison 2: tab. 88. 1805.

Lectotypus (designated here): [AUSTRALIA]: Hort. Malmaison, Ventenat s.n. (G [G00341502 upper specimen]!).

= Leptospermum arachnoides Gaertn.

Notes. - A single herbarium sheet was found in Ventenat's herbarium, on which two gatherings are mounted, one from Cels's garden [G00341502 lower specimen] and the other from Malmaison. The Malmaison collection is here designated as the lectotype because the plant has been published in Jardin de Malmaison. No type was designated in Thomson (1999)'s revision of the genus Leptospermum J.R. Forst. \& G. Forst. in Australia.
40. Lithospermum decumbens Vent., Descr. P1. Nouv.: tab. 37. 1801.

\section{$\equiv$ Arnebia decumbens (Vent.) Coss. \& Kralik}

Lectotypus (designated here) : IraQ: de Bagdad à Mossoul, Bruguière E Olivier s.n. (P [P03877945]!; isolecto- : G-DC [G00149288]!; probable isolecto- : G [G00341671]!).

Notes. - A single specimen has been found in Ventenat's herbarium. The collection probably lost its original label and only the locality "Barbarie" is noted though not in Ventenat's handwriting. Two Bruguière and Olivier collections with a clear reference to the type locality (Baghdad and Mosul in Iraq) have been located. We designate the sheet at $\mathrm{P}$ [P03877945] as the lectotype because it is more complete than the more fragmented collection in G-DC. We consider the collection in Ventenat's herbarium at $\mathrm{G}$ as a probable isolectotype.

41. Lunaria suffruticosa Vent., Descr. P1. Nouv.: tab. 19. 1800.

$\equiv$ Fibigia suffruticosa (Vent.) Sweet

Lectotypus (designated here): IRAN: sine loc., [Bruguière E'] Olivier s.n. (G [G00341542]!; isolecto-: G-DC [G00204574, G00204706]!, P [P00747689]!).

Notes. - The plant cultivated in Cels's garden originated from a Michaux collection from Persia. Ventenat in Descriptions (1800: tab. 19) nevertheless wrote that he had obtained the fruits from Olivier from the same locality where Michaux had collected. In Ventenat's herbarium, no cultivated plant exists. A single collection carries the label: "Lunaria sp. n. e persia Ded. Olivier". This collection is here designated as the lectotype with duplicates in G-DC and P. The Michaux collections originating from Persia are here considered as probable elements of original material (G-DC [G00204704], $\mathrm{P}$ [P00747690]). Cullen (1965: 356) in his treatment of the genus Fibigia Medik. for Flora of Turkey regarded both Michaux and Olivier collections as syntypes.

A specimen annotated in Ventenat's hand "Lunaria suffruticosa H. Cels pl. 19." and in D. F. K. v. Schlechtendal's hand "Ventenat. W[illdenow]" (B-W n $\left.{ }^{\circ} 11945\right)$ is also avalaible for interpretation of this name.

42. Melaleuca gnidiifolia Vent., Jard. Malmaison 1: tab. 4. 1803.

Lectotypus (designated here): [AUSTRALIA] : Hort. Malmaison, Ventenat s.n. (G [G00341462]!; isolecto- : G-DC [G00659775]!).

= Melaleuca thymifolia $\mathrm{Sm}$. 
Notes. - Two specimens of a single gathering have been located: one in Ventenat's herbarium at $\mathrm{G}$ and a fragment in G-DC with the mention "M. B. Delessert 1816". The later was therefore part of Ventenat's herbarium before Delessert gave this fragment Candolle (see introduction). The collection from Empress Joséphine's garden in Ventenat's herbarium is designated here as the lectotype.

43. Melaleuca myrtifolia Vent., Jard. Malmaison 1 : tab. 47. 1804.

Lectotypus (designated here): Australia : sine loc., L. Ventenat s.n. (holo-: G [G00341463]!).

Notes. - Two gatherings have been located for this species. The specimen collected by Louis Ventenat in Australia in Ventenat's herbarium and the cultivated specimen from Malmaison in G-DC [G00659788]. The Louis Ventenat collection in Ventenat's herbarium is designated here as the lectotype.

44. Mesembryanthemum carinatum Vent., Jard. Malmaison 2: tab. 109. 1805.

Lectotypus (designated here): [SOUTH Africa] : (Ventenat, Jard. Malmaison 2: tab. 109. 1805) (Fig. 8).

= Erepsia lacera (Haw.) S. Liede

Notes. - No original material has been located of Mesembryanthemum carinatum. Surprisingly this species is not mentioned in CAndolle (1828)'s Mesembryanthemum L. treatment. Plate 109 in the second volume of Jardin de Malmaison is therefore designated as the lectotype as long as no original material has been located.

45. Metrosideros lophantha Vent., Descr. P1. Nouv.: tab. 69. 1802.

Lectotypus (designated here) : [AuSTralia] : Hort. Cels, Ventenat s.n. (G [G00341539]!; isolecto-: G [G00341540, G00341541]!).

$=$ Callistemon salignus $(\mathrm{Sm}$.) Colv. ex Sweet

Notes. - Three specimens of a single gathering have been located in Ventenat's herbarium at G. They represent the plant cultivated in Cels's garden. The more complete collection is designated here as the lectotype.

46. Mimosa floribunda Vent., Choix Pl.: tab. 13. 1803.

$\equiv$ Acacia floribunda (Vent.) Willd.

Lectotypus (designated here): [Australia]: Hort. Cels, Ventenat s.n. (G [G00341448]!; isolecto-: G [G00341446]!, G-DC [G00652311]!, probable G-DC [G00652351]!).
Notes. - Two specimens of a single gathering have been located: one in Ventenat's herbarium at $G$ and a fragment in G-DC with the mention "M. B. Delessert 1816". The later was therefore part of Ventenat's herbarium before Delessert gave this fragment to Candolle (see introduction). The collection from Cels's garden in Ventenat's herbarium is designated here as the lectotype. A specimen with the mention "h. cels" in G-DC may represent a duplicate.

47. Mimosa juniperina Vent., Jard. Malmaison 2: tab. 64. 1804.

Lectotypus (designated here): [Australia]: Hort. Malmaison, Ventenat s.n. (G [G00341521]!; isolecto- : G [G00341519]!).

= Acacia ulicifolia (Salisb.) Court

Notes.-Two gatherings have been found in Ventenat's herbarium at G. The collection from Port Jackson in Australia [G00341520] where the plant has been discovered and the plant cultivated in Malmaison. We designate the cultivated collection as the lectotype as it is more complete and includes both flowers and fruits.

48. Myrtus horizontalis Vent., Jard. Malmaison 1: tab. 60. 1804.

Lectotypus (designated here): [WEST INDIES] : Hort. Malmaison, Ventenat s.n. (G [G00341464]!; isolecto- : G-DC [G00658454]!).

= Eugenia disticha $(\mathrm{Sw}.) \mathrm{DC}$.

Notes. - Two specimens of a single gathering have been located: one in Ventenat's herbarium at $\mathrm{G}$ and a fragment in G-DC with the mention "M. B. Delessert 1816". The later was therefore part of Ventenat's herbarium before Delessert gave this fragment to Candolle (see introduction). The collection in Ventenat's herbarium is designated here as the lectotype.

49. Nemesia foetens Vent., Jard. Malmaison 1: tab. 41. 1804.

Lectotypus (designated here): [SouTH AfricA] : Hort. Malmaison, Ventenat s.n. (G [G00341534]!; isolecto- : G-DC [G00654953]!).

$=$ Nemesia fruticans (Thunb.) Benth.

Notes. - Two specimens of a single gathering have been located: one in Ventenat's herbarium at $\mathrm{G}$ and a fragment in G-DC with the mention "h. Ventenat. B. Delessert 1810 [sic]". The later was therefore part of Ventenat's herbarium before Delessert gave this fragment to Candolle (see introduction). The collection in Ventenat's herbarium is designated here as the lectotype. 


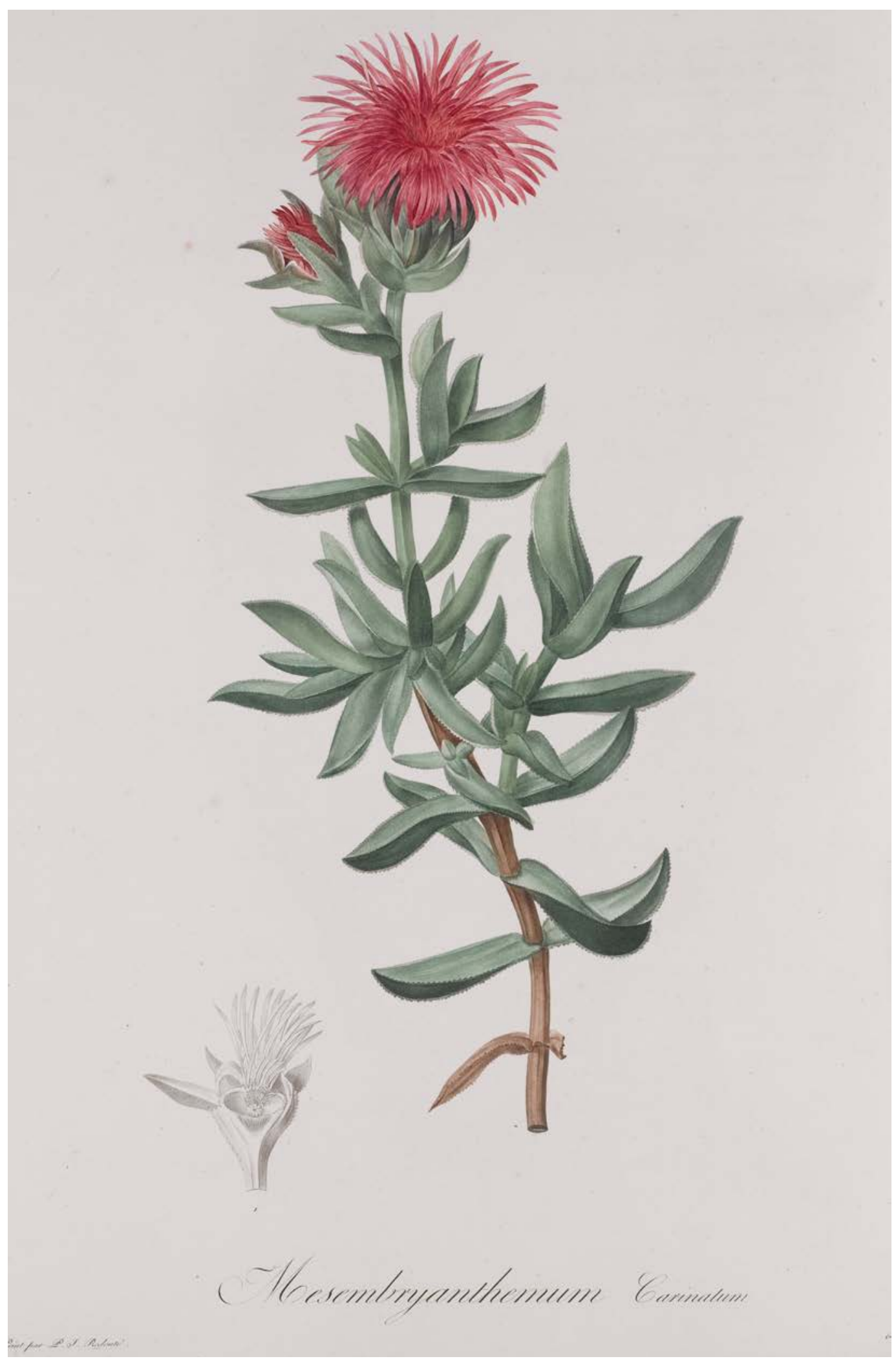

Fig. 8. - Lectotype of Mesembryanthemum carinatum Vent. Colour copper engraving by Allain

based on a watercolour by Pierre-Joseph Redouté. P.E. Ventenat, Jardin de la Malmaison: tab. 109. 1805.

[Bibliothèque des Conservatoire et Jardin botaniques de la Ville de Genève]. 
50. Nemesia linearis Vent., Jard. Malmaison 1: sub tab. 41. 1804.

Lectotypus (designated here): South Africa: Cape, Sonnerat s.n. (P-JU n 6170 [P00667181]!).

Notes. - No specimen has been located at G. Ventenat clearly referred to Jussieu's herbarium ("ex Juss.") and the only specimen located for this species in $\mathrm{P}-\mathrm{JU}$ is here designated as the lectotype.

51. Nepeta longiflora Vent., Descr. P1. Nouv.: tab. 66. 1802.

Lectotypus (designated here): [IRAN]: Hort. Cels, Ventenat s.n. (G [G00341508 excl. left-hand specimen]!; isolecto-: P-JU n 5385 [P00658191]!).

Notes. - The name Nepeta longiflora has been validated in Descriptions in 1802 based on a plant cultivated in Cels's garden originating from a Bruguière and Olivier collection from $\mathrm{Mt}$ Albours in Persia. The only specimen in Ventenat's herbarium is a mixed gathering with material from Cels's garden and Bruguière and Olivier. The plant cultivated in Cels's garden is designated here as the lectotype with a duplicate in P-JU. A single collection from Mt Albours collected by Bruguière and Olivier has been located in G-BOIS [G00330752] and is here considered as original material. Several collections from the expedition of Bruguière and Olivier in Persia are held at P [P04177880, P04177881, P04177886, P04177888] and one in G-DC [G006554857] but none seems to be from Mt Albours but rather from Teheran. They may also represent elements of original material of Nepeta longifora.

52. Nicotiana undulata Vent., Jard. Malmaison 1: tab. 10.1803 [nom illeg.] [non $N$. undulata Ruiz \& Pavon].

= Nicotiana suaveolens Lehm.

Lectotypus (designated here) : [AUSTRALIA] : Hort. Malmaison, Ventenat s.n. (G [G00341437]!; isolecto-: G [G00341600]!).

Notes. - Two specimens of a single gathering have been located in Ventenat's herbarium at G. They represent the plant cultivated in Joséphine's garden. The more complete collection is here designated as the lectotype.

\section{Notelaea ligustrina Vent., Choix P1.: sub tab. 25.1804.}

Lectotypus (designated here): Australia. Tasmania: Golfe d'Entrecasteaux, près la terre de Diemen, Leschenault de la Tour s.n. (P-JU n ${ }^{\circ}$ 4889A [P00657313]!; isolecto-: $\mathrm{G}$ [G00341528]!).
Notes. - The extant collection in Ventenat's herbarium is a sterile clastotype. Ventenat clearly refers to Jussieu's herbarium in the description of this species and the more complete material in P-JU is here designated as the lectotype. Green (1968: 364) in the revision of the genus Notelaea Vent. cited as type a Leschenault s.n. collection "ex Herb. Jussieu \& Ventenat". This can hardly be accepted as an implicit lectotypification as no depository is indicated.

54. Oliveria decumbens Vent., Descr. P1. Nouv.: tab. 21. 1801. Lectotypus (designated here): [IRAO]: Hort. Cels, Ventenat s.n. (G [G00341532]!; isolecto-: G [G00341531]!, $\mathrm{P}-J U \mathrm{n}^{\circ} 10396$ [P00667197]!).

Notes. - Two gatherings have been located. The original material cultivated in Cels's garden in Ventenat's herbarium with a duplicate in P-JU and two specimens from Iraq collected by Bruguière and Olivier in G-DC [G00664660, G00664720]. The better preserved Cels's garden collection in Ventenat's herbarium is here designated as the lectotype.

55. Pelargonium radicatum Vent., Jard. Malmaison 2: tab. 65. 1804.

Typus: [SouTH AFrica]: Hort. Malmaison, Ventenat s.n. (holo-: G [G00341658]!) (Fig. 9).

$=$ Geranium ciliatum Andrews in Bot. Repos. 4: tab. 247. 1802 [nom. illeg.] [non G. ciliatum Cav.].

Notes. - Ventenat in Jardin de Malmaison (1804: tab. 65) cited the later homonym Geranium ciliatum Andrews as a synonym of his Pelargonium radicatum. We consider Ventenat's name as independent of Andrews' illegitimate name and not as a replacement name. We therefore consider the collection in the Ventenat herbarium as the holotype.

56. Phebalium squamulosum Vent., Jard. Malmaison 2: tab. 102. 1805 .

Lectotypus (designated here): [AUSTRALIA]: Hort. Malmaison, Ventenat s.n. (G [G00340116]!; isolecto-: G-DC [G00219424]!).

Notes. - Two specimens of a single gathering have been located: one in Ventenat's herbarium at $\mathrm{G}$ and a fragment in G-DC with the mention "M. B. Delessert 1816" (Fig. 6). The later was therefore part of Ventenat's herbarium before Delessert gave this fragment to Candolle (see introduction). The collection in Ventenat's herbarium is designated here as the lectotype. 

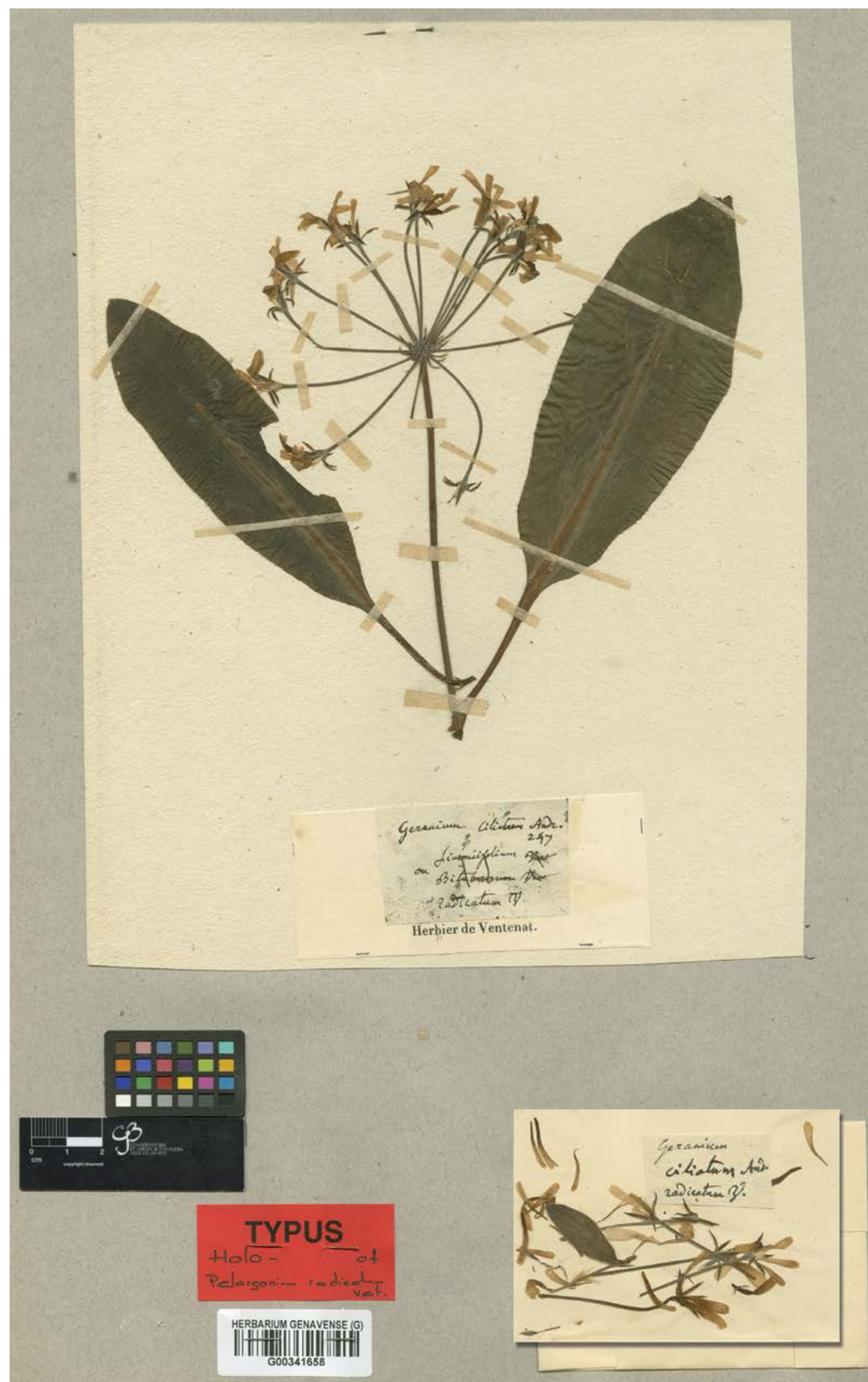

Fig. 9. - Holotype of Pelargonium radicatum Vent. at G. 
57. Phylica oleifolia Vent., Jard. Malmaison 1: sub tab. 57. 1804.

Neotypus (designated here): [South Africa]: "Hort. Reg. Paris", Anon. s.n. (P-JU n 16184 [P00667206]!)

(Fig. 10).

Notes. - No type material has been located for Phylica oleifolia. A specimen in the P-JU herbarium bears in Jussieu's handwriting: "Phylica oleifolia Ventn. Mss.". This cultivated collection from the "Jardin du Roi" [ex Hort. Reg. Paris] is dated 1787. This garden is now known as the "Jardin des Plantes". Serge Haemmerli (Z) currently undertakes a revision of the genus Phylica L. and considers Phylica oleifolia as a good species (Haemmerli, pers. comm.). The collection is here designated as neotype because it probably originates from the cultivated plant that Ventenat described in 1804.

58. Phylica squarrosa Vent., Jard. Malmaison 1: sub tab. 57. 1804.

Lectotypus (designated here): [SouTH AFrICA]: Hort. Malmaison, Ventenat s.n. (G [G00341545]!; isolecto-: G-DC [G00476386]!).

$=$ Phylica plumosa L.

Notes. - Two specimens of a single gathering have been located: one in Ventenat's herbarium at $\mathrm{G}$ and a fragment in G-DC with the mention "M. B. Delessert 1816". The later was therefore part of Ventenat's herbarium before Delessert gave this fragment to Candolle (see introduction). The collection in Ventenat's herbarium is designated here as the lectotype.

59. Phylica thymifolia Vent., Jard. Malmaison 1: tab. 57.1804.

Lectotypus (designated here): [SouTH AFRICA]: Hort.

Malmaison, Ventenat s.n. (G [G00341550]!; isolecto- : G-DC [G00476500]!).

Notes. - Two specimens of a single gathering have been located: one in Ventenat's herbarium at $G$ and a fragment in G-DC with the mention "M. B. Delessert 1816". The later was therefore part of Ventenat's herbarium before Delessert gave this fragment to Candolle (see introduction). The collection in Ventenat's herbarium is designated here as the lectotype.

60. Picridium ligulatum Vent., Jard. Malmaison 2: tab. 68. 1804.

$\equiv$ Reichardia ligulata (Vent.) G. Kunkel \& Sunding

Lectotypus (designated here): [MoRocco]: Hort. Malmaison, Ventenat s.n. (G [G00341477]!).
Notes. - Two gatherings have been located for this species. A collection in G-DC [G004922721] represents the original material from Broussonet and a collection of cultivated material is still extant in Ventenat's herbarium. We therefore designate the cultivated plant still in Ventenat's herbarium as the lectotype.

61. Platylobium obcordatum Vent., Jard. Malmaison 1 : sub tab. 31. 1804.

\section{$\equiv$ Bossiaea obcordata (Vent.) Druce}

Lectotypus (designated here): Australia. Queensland: Nouvelle-Hollande SW, L. Ventenat s.n. (G [G00096594]!).

Notes. - Two gatherings are present in Ventenat's herbarium. The collection from Queensland [Nouvelle-Hollande $\mathrm{du}$ Sud-Ouest] and a cultivated specimen from Malmaison [G00096595]. We designate the specimen collected in the wild as the lectotype. THompson (2012) failed to designate a lectotype in his revision of the genus Bossiaea Vent. for eastern Australia.

62. Poitea galegoides Vent. in Mém. Cl. Sci. Math. Inst. Natl. France 8: 17. 1807 [cited in Choix Pl.: tab. 36. 1807].

Typus: Dominican Republic / Haiti: sine loc., Poiteau s.n. (holo-: G [G00370600]!; iso-: P [P02925169]!) .

Notes. - Lavin (1992: 45) in his revision of the genus Poitea cited a Poiteau collection as holotype in G-DC herbarium. The collection held at $G$ in Ventenat's herbarium is clearly the holotype and no duplicate has been located in G-DC. Another Poiteau collection at P is considered as an isotype.

63. Polygonum polygamum Vent., Descr. P1. Nouv.: tab. 65. 1802.

Lectotypus (designated here): [UNITED STATES]: Hort. Cels, Ventenat s.n. (G [G00341643 specimen on the left]!) (Fig. 11).

Notes. - The only collection of this species in Ventenat's herbarium is mixed: a Ventenat collection from Cels's garden and fragments of possible isotypes (G [G00341643 specimen on the right]) of Polygonella parvifolia Michx., a name published one year later (Michaux, 1803) (with a duplicate in P-JU n ${ }^{\circ}$ 4290 [P00681748]). The latter name is probably based on the same original material as mentioned on the sheet by Vernon $\mathrm{M}$. Bates (Fig. 11) but we failed to find convincing type material in $\mathrm{P}-\mathrm{MICH}$ due to the complicated taxonomy of the mixed collections and leave this to a specialist of this genus. Horton (1963: 198) designated tab. 65 of Descriptions in 1802 as the lectotype 


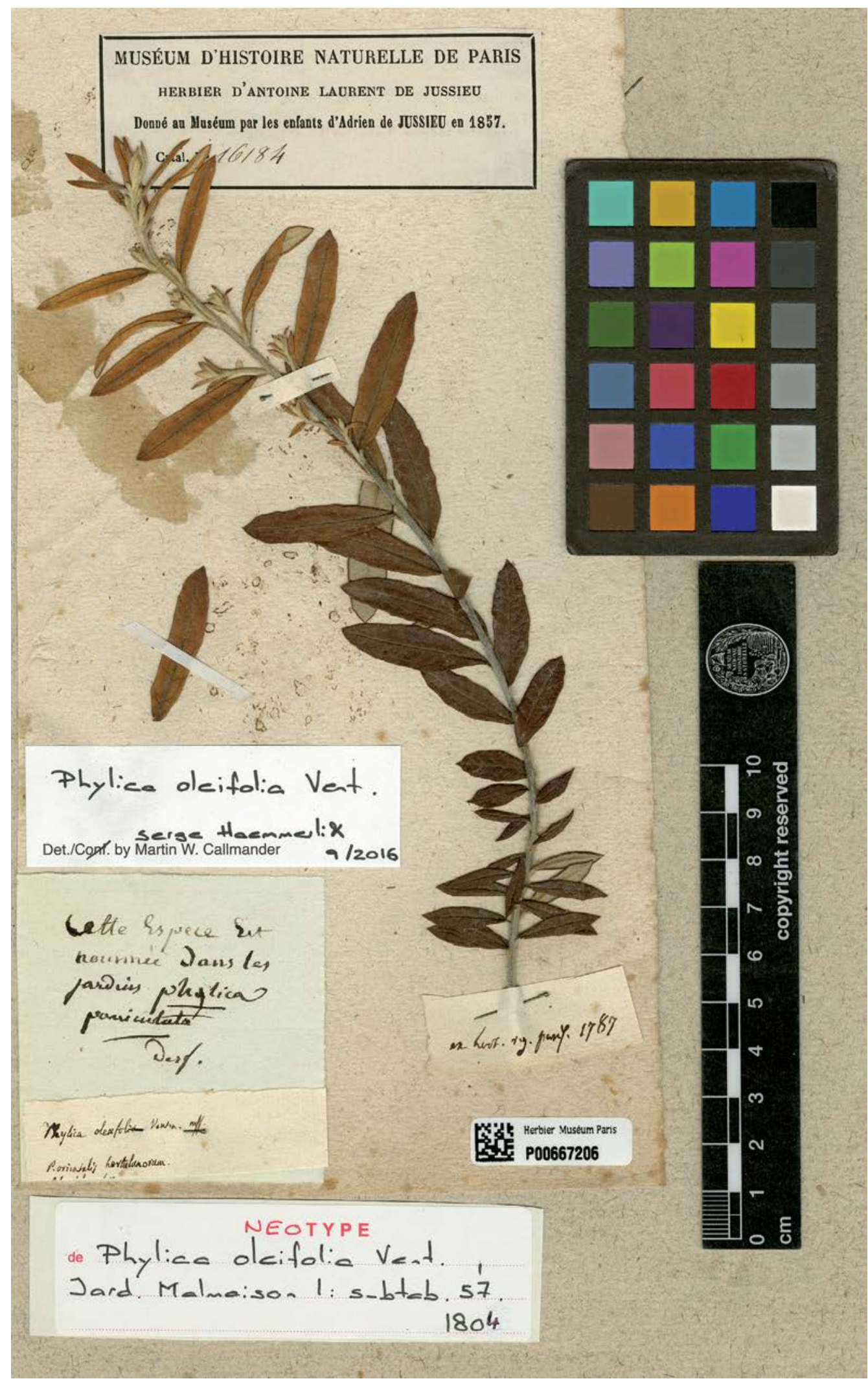

Fig. 10 . - Neotype of Phylica oleifolia Vent. at P-JU.

[๑ Muséum national d'Histoire naturelle, Paris] 
for the name Polygonum polygamum but as original material has been found, our lectotypification supersedes the previous one. We designate Ventenat's collection as the lectotype (specimen on the left of the sheet marked with an asterix). Recent molecular phylogenetic data show that Polygonella Michx. is embedded in Polygonum L. and Polygonella is currently recognised at the subsectional level within Polygonum (Schuster et al., 2011).

64. Pongamia sericea Vent., Jard. Malmaison 1: sub tab. 28.1803. $\equiv$ Millettia sericea (Vent.) Benth.

Lectotypus (designated here): INDONESIA. Java : sine loc., IX.1794-V.1796, Lahaie 2189 (P [P02753433]!; isolecto- : $\mathrm{P}[\mathrm{P} 02753436] !)$.

Notes. - Ventenat in Jardin de Malmaison (1803 : tab. 28) described a new genus Pongamia Vent. based on the illeg. name $P$. glabra Vent. The generic name Pongamia is a rejected name [nom. rejic.] against Millettia Wight \& Arn., a conserved name [nom. cons.] published by Wight \& Arnott in 1834. In the first volume of Jardin de Malmaison, Ventenat also published two further species as addenda: P. grandiflora Vent. and P. sericea Vent. Both species were based on collections made by Felix de Lahaie (1767-1829), while he served as gardener on the Entrecasteaux Expedition. Lahaie's herbarium was bought by the MNHN in 1879 but some collections are also part of Ventenat's herbarium (Guillaumin, 1910). Among the material in the Ventenat herbarium no specimens of Pongamia are extant and therefore the name P. sericea had to be lectotypified on collections kept in P. The name Pongamia grandiflora, currently accepted as Derris elliptica (Wall.) Benth., has been implicitly lectotypified by ADEMA (2000: 420) with a specimen in the P-JU herbarium ( $\left.\mathrm{n}^{\circ} 15666\right)$.

65. Pultenaea ericoides Vent., Jard. Malmaison 1: tab. 35. 1804.

\section{$\equiv$ Aotus ericoides (Vent.) G. Don}

Lectotypus (designated here) : [AusTralia] : Hort. Malmaison, Ventenat s.n. (G [G00364790]!; isolecto-: G-DC [G00488197]!).

Notes. - Two specimens of a single gathering have been located: one in Ventenat's herbarium at $\mathrm{G}$ and a fragment in G-DC with the mention "M. B. Delessert 1816". The later was therefore part of Ventenat's herbarium before Delessert gave this fragment to Candolle (see introduction). The collection in Ventenat's herbarium is designated here as the lectotype.

66. Rafnia retusa Vent., Jard. Malmaison 1: tab. 53. 1804.

$\equiv$ Templetonia retusa (Vent.) $\mathrm{R}$. Br.

Lectotypus (designated here) : [AUSTRALIA]: Hort. Cels, Ventenats.n. (G [G00341503]!).
Notes. - Two gatherings are present in Ventenat's herbarium. A flowering specimen from Cels's garden and the fruiting specimen [G00341504] originally brought back by his brother Louis Ventenat from Australia while he took part in the "Entrecasteaux Expedition" (see introduction). The flowering specimen from Cels's garden is here designated as the lectotype. Ross (1982:3) in the revision of the genus Templetonia R. Br. cited a specimen at $G$ as holotype but two specimens exist representing two gatherings. This cannot be considered as an implicit lectotypification.

67. Ranunculus echinatus Vent., Descr. P1. Nouv.: tab. 73. 1802.

Lectotypus (designated here): [UNITED STATEs]: Hort. Cels, Ventenat s.n. (G [G00341564]!; isolecto- : G-DC [G00130232]!).

= Ranunculus muricatus L.

Notes. - Two specimens of a single gathering have been located: one in Ventenat's herbarium at $\mathrm{G}$ and a fragment in G-DC with the mention "ex herb. Ventenat". The collection in Ventenat's herbarium is designated here as the lectotype.

68. Redoutea heterophylla Vent., Descr. P1. Nouv.: tab. 11.1800.

= Cienfuegosia heterophylla (Vent.) Garcke

Lectotypus (first step designated by FRYXELL, 1969: 211; second step designated here) : UNITED STATES. Virgin Islands: St. Thomas, Riedlé s.n. (G [G00353087 excl. fragm. packet]!; isolecto-: FI [FI006089] image seen, $\mathrm{P}$ [P02285953, P02285954, P02285955]!, P-JU n 12403 [P00671970]!).

Notes. - Fryxell (1969) cited the material in Ventenat's herbarium as holotype. However, this specimen [G00353087] is a mixed gathering and a second step lectotypification is necessary. A fragment packet contains original material obtained from the plant cultivated in Cels's garden and from the Museum in Paris ("Mus. Nat."). On the same sheet is represented the material from St. Thomas collected by Riedlé. We designate the latter as the lectotype. Four more collections are all original material from Riedlé (or in Baudin herbarium as leg. Riedlé, see above) and considered as isolectotypes.

A specimen annotated in Ventenat's hand "Redoutea heterophylla Hort. Cels pl. XI“ and in D. F. K. v. Schlechtendal's hand "Ventenat. W[illdenow]" (B-W n 12834$)$ is also available for the interpretation of this name.

69. Robinia viscosa Vent., Descr. P1. Nouv.: tab. 4. 1800.

Lectotypus (designated here): [UNITED STATEs]: Hort. Cels, Ventenat s.n. (G [G00341607]!; isolecto- : P-JU n ${ }^{\circ}$ 15222 [P00667174]!). 


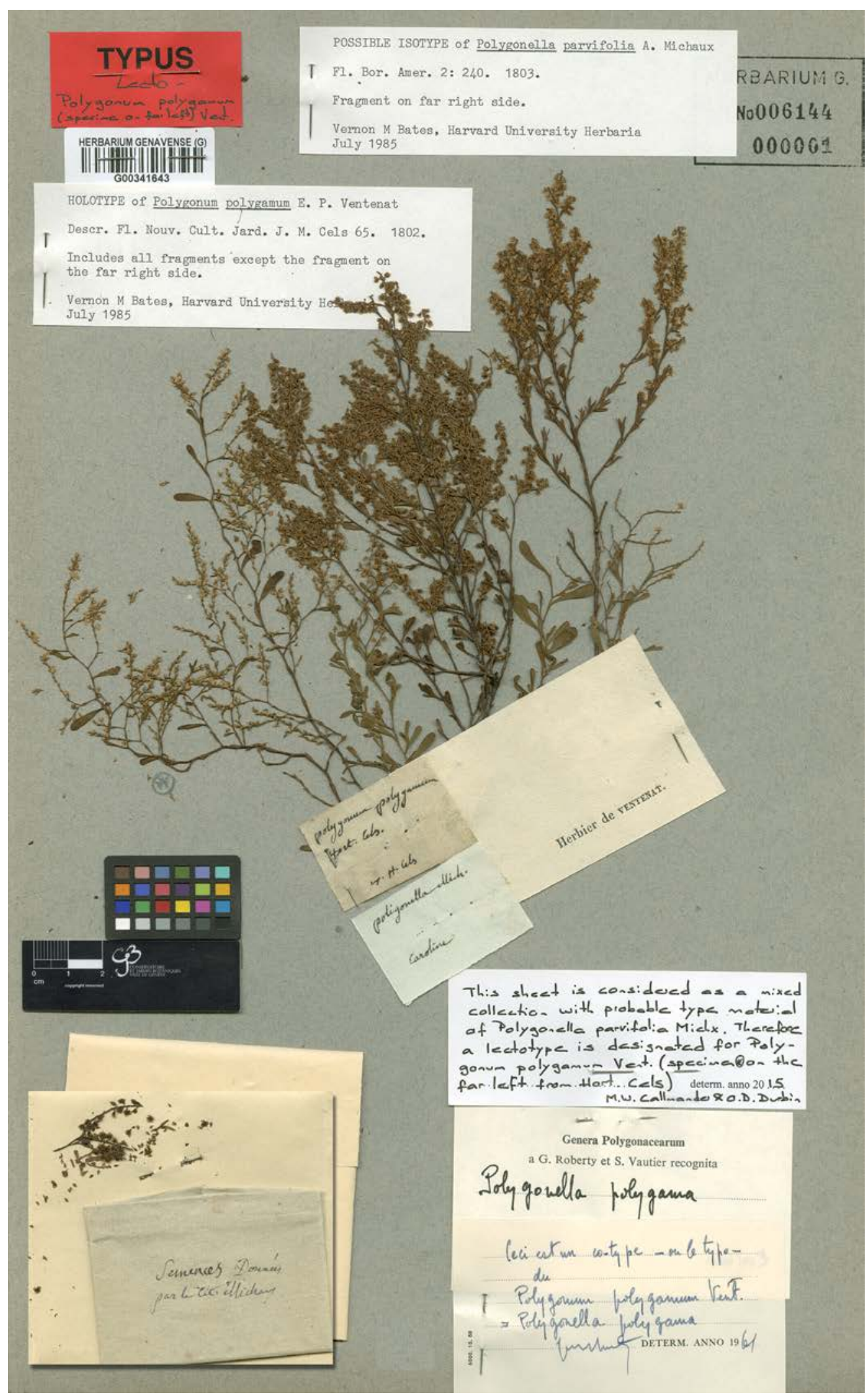

Fig. 11. - Mixed gathering on the single sheet of Polygonum polygamum Vent. at $\mathrm{G}$ [see under $\mathrm{n}^{\circ} 63$ for further explanations]. 
Notes. - Two gatherings are present in Ventenat's herbarium: the collection from Michaux and a cultivated specimen from Cels's garden. We designate the cultivated specimen as the lectotype because it is a more complete collection with a complete inflorescence. An isolectotype from Cels's garden has been located in P-JU. Michaux's collection from South Carolina ("Caroline méridionale") is considered as an element of original material (G [G00341606], G-DC [G00478142]!, $\mathrm{P}$ [P02924476], P-MICH [P00667178]).

\section{Rosa kamtchatica Vent., Descr. P1. Nouv.: tab. 67.1802.}

Lectotypus (designated here): [RUSSIA]: Hort. Cels, Ventenat s.n. (G [G00341465]!; isolecto-: G [G00341452]!).

Notes. - Two specimens of a single gathering have been located in Ventenat's herbarium at G. They represent the plant cultivated in Cels's garden. The more complete collection is designated here as the lectotype.

71. Salvia acuminata Vent., Descr. P1. Nouv.: tab. 50. 1801 [nom. illeg.] [non S. acuminata Ruiz \& Pav.].

Lectotypus (designated here): UNITED STATEs. South Carolina: Michaux s.n. (G [G00341608]!; isolecto- : P-JU n 5261 [P00657979]).

\section{= Salvia azurea Michx. ex Vahl}

Notes. - Two gatherings are present in Ventenat's herbarium. The Michaux collection from Carolina and a cultivated specimen from Cels's garden [G00341573]. We designate the Michaux collection as the lectotype because it better represent the morphology of the plant in the wild.

72. Salvia compressa Vent., Descr. P1. Nouv.: tab. 59. 1801.

Lectotypus (designated here): [IRAO]: Hort. Cels, Ventenat s.n. (G [G00341501]!; isolecto- : C [C10013209]!).

Notes. - The name Salvia compressa was validated in Descriptions in 1801 based on a specimen cultivated in Cels's garden originating from a Bruguière and Olivier collection from Iraq (between Mosul and Baghdad). The only specimen in Ventenat's herbarium from Cels's garden is designated as the lectotype with a duplicate in C. Four specimens collected between Mosul and Baghdad by Bruguière and Olivier have been located in G-BOIS [G00330751] and P [P02888639, $\mathrm{P} 02888640, \mathrm{P} 02888641]$. They are here considered as elements of original material. HedGE (1982: 426) in his revision for $\mathrm{Fl}$. Iranica did not specify the herbarium where the type specimen has been desposited; this cannot be considered as an implicit lectotypification.
73. Sideritis pullulans Vent., Descr. P1. Nouv.: tab. 98. 1803.

Lectotypus (designated here): SyRIA: sine loc., Bruguière E Olivier s.n. (G [G00341497]!).

Notes. - Two gatherings are present in Ventenat's herbarium. A sterile cultivated specimen from Cels's garden [G00341642] and the specimen from Syria collected by Bruguière and Olivier. The latter is a flowering specimen and designated as the lectotype. No specimen has been located in $\mathrm{P}$.

74. Solenandria cordifolia P. Beauv. ex Vent., Jard. Malmaison 2: tab. 69. 1804.

Lectotypus (designated here) : UNITED STATES : "Caroline”, Palisot de Beauvois s.n. (G [G00341549]!; isolecto-: G [G00341547, G00341548]!).

$=$ Galax urceolata (Poir.) Brummitt

Notes. - Three specimens of a single gathering collected by Ambroise Marie François Joseph Palisot de Beauvois (17521820) have been located in Ventenat's herbarium at G. The more complete collection is here designated as the lectotype.

75. Spartium parviflorum Vent., Descr. P1. Nouv.: tab. 87.1802.

Lectotypus (designated here): [TURKEY]: Hort. Cels, Ventenat s.n. (G [G00341544]!; isolecto-: G [G00341537]!).

$=$ Gonocytisus angulatus $(\mathrm{L}$.) Spach

Notes. - The name Spartium parviflorum was validated in Descriptions in 1802. It is based on a specimen cultivated in Cels's garden originating from a Bruguière and Olivier collection from Turkey (Mundania). Two specimens in Ventenat's herbarium from Cels's garden have been located and the more complete collection [G00341544] is here designated as the lectotype. Five specimens collected in Turkey by Bruguière and Olivier have been located in G-BOIS [G00341543], G-DC [G00477269] and P [P02953058, P02953060, P02953062]. These are all considered as elements of original material.

76. Spathodea corymbosa Vent. in Mém. Cl. Sci. Math. Inst. Natl. France 8: 19.1807 [cited in Choix Pl.: tab. 40. 1807].

$\equiv$ Bignonia corymbosa (Vent.) L.G. Lohmann

Typus: Trinidad : sine loc., Riedlé s.n. (holo-: P [P00481551]!) (Fig. 12).

Notes. - No collection of this species has been found at G. A collection at $\mathrm{P}$ clearly comes from the Ventenat herbarium. It is the only example we have found of a Ventenat label at P. It is designated here as the holotype (Fig. 12). This collection may have been in the herbarium of one of Ventenat's contemporaries when 


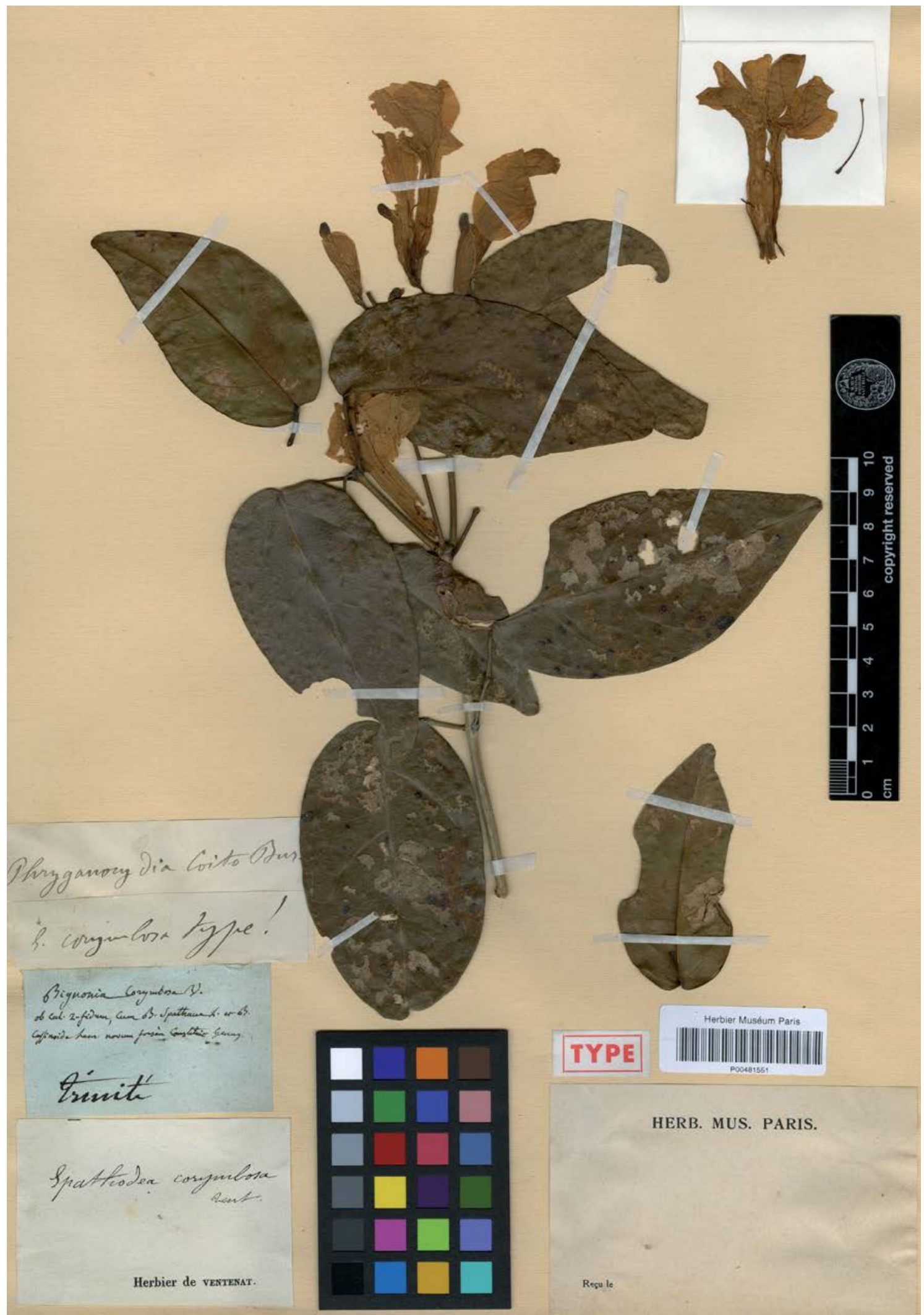

Fig. 12. - Holotype of Spathodea corymbosa Vent. in P. This sheet is the only one found outside G with a label typical of Ventenat. [@ Muséum national d'Histoire naturelle, Paris] 
his own herbarium has been sold to Delessert (see introduction). Both LoHmann (2008) and LoHmann \& TAYlor (2012) also considered this Riedlé collection as holotype.

\section{Statice fasciculata Vent., Descr. P1. Nouv.: tab. 38. 1801.}

Lectotypus (designated here): [FrANCE. Corsica]: Hort. Cels, Ventenat s.n. (G [G00341427]!).

= Armeria pungens (Link) Hoffmanns. \& Link

Notes. - The name Statice fasciculata was validated on the basis of a collection brought back from Corsica by La Billardière and cultivated in Cels's garden. After the latin diagnosis, Ventenat cited two collections from Herb. Vaillant. On the only sheet at $\mathrm{G}$, the text of one of these collections is copied and placed near the fragment packet. We believe that Ventenat had probably obtained from $\mathrm{P}$ a clastotype of $\mathrm{P} 05406334$ and we therefore consider the collection at $\mathrm{G}$ as a mixed gathering. We designate the cultivated specimen from Cels's garden as the lectotype. The La Billardière collections present in Webb's herbarium at FI-W [FI016966, FI016967] are considered as elements of original material as also the two collections in $\mathrm{P}$ [P05406334] and P-TRF [P00666376] (Fig. 13) respectively.

78. Sterculia grandiflora Vent., Jard. Malmaison 2: sub tab. 91. 1805.

Lectotypus (designated here): MAURITIUS: sine loc., Commerson s.n. (P-JU n ${ }^{\circ} 12446$ [P00667176]!; isolecto- $\mathrm{G}$ [G00015287]!).

= Cola acuminata (P. Beauv.) Schott \& Endl.

Notes. - After a short latin diagnosis, Ventenat stated in Jardin de Malmaison 2: sub tab. 91: "ex Herbario D. de Jussieu, ex Herbarium D. de Lamarck”. One specimen has been found at G and this collection is a clastotype of a collection by Philibert Commerson (1727-1773) from Mauritius where the plant is cultivated. We designate the collection in P-JU as the lectotype as it is more complete and has been used by Ventenat for the description of this species. The two collections in P-LA [P00287711, P00287712] are considered as elements of original material.

79. Sterculia monosperma Vent., Jard. Malmaison 2: tab. 91. 1805.

Lectotypus (first step designated by TANTRA, 1976: 154; second step designated here): [CHINA]: cultivated in India [more probably in Indonesia], Anon. s.n. (G [G00341673]!).

Notes. - Tant RA (1976: 154) designated a collection in "Herb. de Ventenat" at G as the type with no more information. This cannot be accepted as an implicit lectotypification since two gatherings exists at $\mathrm{G}$ in Ventenat's herbarium: the collection cultivated in Cels's garden and a collection probably from Indonesia. The origin of the collection that Ventenat received is doubtful. Sterculia monosperma is endemic to China, the Malay Peninsula and Java (Tranta, 1976). Ventenat coined the name $S$. monosperma because his specimen possessed a single seeded fruit. The fruiting collection of doubtful origin at $\mathrm{G}$ [G00341673] is therefore designated here as the lectotype. The cultivated collection in flower from Cels's garden [G00358626] is considered as an element of original material.

80. Sterculia rubiginosa Vent., Jard. Malmaison 2: sub tab. 91. 1805.

Lectotypus (designated here): INDONESIA. Java: sine loc., Commerson s.n. (P-JU n ${ }^{\circ} 12445$ [P00667180]!; isolecto-: $\mathrm{P}[\mathrm{P} 06702127] !)$.

Notes. - Ventenat in Jardin de Malmaison (1805: sub tab. 91) noted: "Java. Ex. Herbar. D.D. de Jussieu et Thouin". In his revision of the genus Sterculia L. in Malesia, TANTra (1976) implicitly designated the lectotype at $\mathrm{P}$, i.e. Thouin 462 , that he had not seen [by mentioning n.v.], with a duplicate at LINN. The Smith herbarium at LINN contains several collection of the Thouin herbarium (STEARN, 1988). It is not clear if these two collections given by TANTRA (1976) as type material are duplicates of the same gathering. The Thouin herbarium contains several of Commerson's collections but we prefer to designate the P-JU collection with a duplicate in the general collection in $\mathrm{P}$ as the lectotype. No collection has been found at $\mathrm{G}$.

81. Styphelia gnidium Vent., Jard. Malmaison 1: tab. 23.1803.

Lectotypus (designated here): [AusTRALIA]: Hort. Malmaison, Ventenat s.n. (P-JU n ${ }^{\circ} 7364+\mathrm{C}$ [P00667208]!).

= Leucopogon parviflorus (Andrews) Lindl.

Notes. - The only collection found in Ventenat's herbarium seems to represent two gatherings from Botany Bay in Australia. Only the specimen on the right-hand of G [G00341499] seems to match the morphology of the species. A more trustful collection has been located in P-JU. It is a cultivated specimen from Malmaison given by Ventenat to Jussieu in 1805 . We designate the latter collection as the lectotype.

82. Tournefortia laurifolia Vent., Choix P1.: tab. 2. 1803.

Lectotypus (designated here): United STATEs. Puerto Rico: sine loc., Riedlé s.n. (P [P00607005]!; isolecto-: $\mathrm{P}$ [P00607006, P00607007, P00607008]!).

= Tournefortia maculata Jacq. 


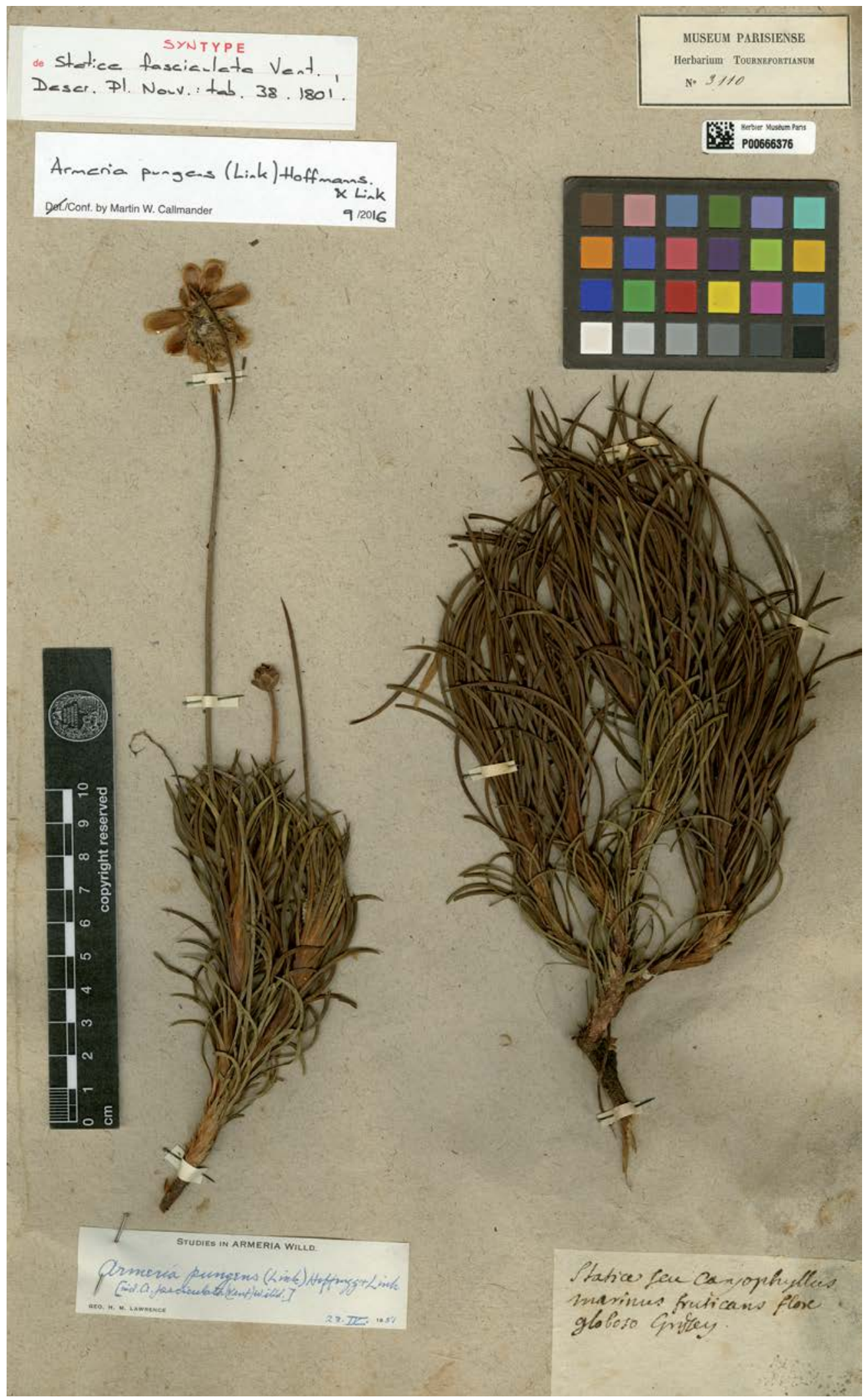

Fig. 13. - Original material of Statice fasciculata Vent. from the Tournefort herbarium in Paris at P-TRF. [@ Muséum national d'Histoire naturelle, Paris] 
Notes. - No specimen was located in Ventenat's herbarium. Several duplicates of the original collections of Riedlé from Puerto Rico have been found at P. The collection [P00607005] is designated here as the lectotype as it clearly served for tab. 2 published in Choix in 1803.

83. Tradescantia rosea Vent., Descr. P1. Nouv.: tab. 24. 1801.

$\equiv$ Callisia rosea (Vent.) D.R. Hunt

Typus: UniTED STATES : "Caroline et Floride", Michaux s.n. (holo-: G [G00341445]! ; iso- : P [P02173797]!, P-MICH [P00667162]!).

Notes. - A single collection has been located in Ventenat's herbarium. This collection is wrongly labelled "Beauvois" standing for Ambroise Marie François Joseph Palisot de Beauvois (1752-1820). However, Ventenat in Descriptions (1801 : tab. 24) referred to material collected by Michaux "dans la Basse-Caroline et dans la Géorgie" that was cultivated in Cels's garden. Two duplicates of the specimen collected in the wild have been found in Paris in $\mathrm{P}$ and in $\mathrm{P}-\mathrm{MICH}$ respectively. Cultivated material kept in MPU (Herb. Thibaud) and P (Herb. Bonpland) labelled as "Hort. Cels" and "Hort. Malmaison" respectively have probably been collected after the validation of the name $T$. rosea in 1801 and should therefore not be considered as original material.

84. Turpinia paniculata Vent. in Mém. Cl. Sci. Math. Inst. Natl. France 8: 6. 1807 [cited in Choix P1.: tab. 31. 1807].

Lectotypus (designated here): Dominican REPUBLIC / Haiti : "St. Domingo", Poiteau s.n. (G [G00341609]!; isolecto- : G [G00341668, G00341670, G00341678]!, G-DC [G00458760]!, P-JU n 16024 [P00678736]!).

$=$ Turpinia occidentalis $(\mathrm{Sw}$.) G. Don

Notes. - Several specimens of a single gathering have been located. A fragment of the Poiteau s.n. collection is in G-DC with the mention "M. B. Delessert 1816" and is here considered to have been previously part of Ventenat's herbarium (see introduction). The single collection in Ventenat's herbarium is designated here as the lectotype.

85. Verbena stricta Vent., Descr. P1. Nouv.: tab. 53. 1801.

Lectotypus (designated here) : UNITED STATES. Illinois : Michaux s.n. (G [G00341491]!; isolecto-: G [G00341489]!, P [P00307087, P00650837]!, P-MICH [P00307085]!).

Notes. - The name Verbena stricta has been validated on the basis of a Michaux collection from Illinois cultivated in Cels's garden. Material collected by Michaux exists in Ventenat's herbarium and cultivated material from the garden of Cels is extant in G-DC [G00657716]. We designate here the Michaux collection at $\mathrm{G}$ as the lectotype as it is in a better state of conservation and represented by two duplicates in $\mathrm{P}$ and one in $\mathrm{P}-\mathrm{MICH}$ respectively. The latter specimen is also the holotype of the illeg. name Verbena rigens Michx. O'LEARY et al. (2010) give as type for $V$. rigens a specimen sine coll. in $\mathrm{P}$ that they have not seen; their typification cannot be accepted.

\section{Acknowledgements}

The authors are first indebted to the Mellon Foundation whose long-time support given to $\mathrm{G}$ and to other herbaria worldwide for the purpose of scanning herbarium specimen, especially type material, has made this study possible and was the prerequisite for this project. MWC and ODD are indebted to Cécile Aupic in charge of the historical collections at $\mathrm{P}$ for her help and interest in our study; to Nicolas Fumeaux for his help and support with collections and nomenclature at $\mathrm{G}$ and Patrick Perret for his early interest in this study. MWC would like to thank Pete Lowry for his support and availability to help with various queries; the whole team of the Library at $G$ for help and assistance while he was preparing this manuscript for publication, especially Pierre Boillat. He also wishes to thank Nicolas Fumeaux for the numerous fruitful discussions about Ventenat and for sharing his knowledge of the $G$ herbaria; Serge Haemmerli for sharing his knowledge of the genus Pbylica; Luce Mansot for permitting access to the documentation kept at the Centre de documentation du Conservatoire Botanique National du Massif Central; Michèle Moulin for her kind assistance during a very nice visit to the Institut de France; Patricia Riedy for her help with scanning the collections and Fig. 8 at G; Berangère Offroy, Véronique Durand and Elodie Lerat for their kind help and assistance at P; Chiara Nepi for our longtime friendship and assistance at FI; Charo Noya for her efficiency at MA; Aurélie Caron for information on the Château de Malmaison; Nathalie Rollet-Bricklin for information on the Sainte-Geneviève Library; Philippe Clerc for mentioning an interesting article on Ventenat; Cyrille Chatelain for his help with Appendix II; Martin Cramatte for his help with Fig. 7 ; and finally the late Gérard Aymonin for reenforcing MWC's curiosity in historical botany and for sharing his irreplaceable knowledge of historical collections at P. Finally the authors thanks Denis Lamy for his critical suggestions to an earlier version of the text; James Compton kindly read a preliminary version of the text and helped to improve the style of this contribution; Patrick Perret carefully read the proofs and spotted several editorial corrections with his sharp eyes and Nick Turland provided important nomenclatural advice. 


\section{Unpublished sources}

Anon. (1806). Notes bibliographiques anonymes sur Cels [Ms 3184/4]. Fonds manuscrits de la Bibliothèque de l'Institut de France, Paris.

Candolle, A.P. DE (1798). Lettre de Candolle à son père [Augustin de Candolle]. 20.VII.1798. Collection privée de Candolle, Genève.

CAndolle, A.P. DE (1830). Catalogue de l'herbier d'après les époques et les origines des échantillons qui le composent. Collection privée de Candolle, Genève.

Delessert, B. (1810). Lettre de Delessert à Candolle. 18.III.1810. Collection privée de Candolle, Genève.

Michaux, A. (1786). Lettre d'André Michaux au citoyen Ventenat [Ms 2454/681-685]. 15.VII.1786. Fonds manuscrits de la Bibliothèque de l'Institut de France, Paris.

Noisette, L.-C. (1807). Lettre de Louis Claude Noisette à Jean Thouin [Ms 2454/XL/586-590]. Fonds manuscrits de la Bibliothèque de l'Institut de France, Paris.

\section{References}

Adema, F. (2000). Notes on Malesian Fabaceae (Leguminosae-Papilionoideae). 7. The genus Millettia. Blumea $45:$ 403-425.

Alava, R. (1987). Zosima. In : Rechinger, K.H. (ed.), Fl. Iranica $162: 473-478$.

Allorge, L. \& O. Ikor (2003). La fabuleuse odyssée des plantes. JC. Lattès, Paris.

Anderberg, A. (1982). The genus Anvillea (Compositae). Nord. J. Bot. 2 : 297-305.

Anon. (2007). Les Ventenat, botanistes limousins. Complément de l'exposition sur l'herbier de Fray-Fournier. Bibliothèque universitaire de Limoges.

APC (2017). The Australian Plant Census [http://www.anbg.gov.au/ chah/apc/index.html].

APD (2017). The African Plant database [http://www.ville-ge.ch/ musinfo/bd/cjb/africa].

APNI (2017). The Australian Plant Name Index [http://www.anbg. gov.au/apni/index.html].

Bernard, P. (1997). Le voyage dans l'Empire othoman, l'Égypte et la Perse de Guillaume-Antoine Olivier, naturaliste et envoyé de la République (1792-1798). Compt.-Rend. Séances Acad. Inscrip. Belle-lettres 141: 1157-1244.

BoDARD, M. (1962). Contributions à l'étude systématique du genre Cola en Afrique Occidentale. Ann. Fac. Sci. Univ. Dakar 7:1-187.

Bonnemains, J. (ed.) (2000). Mon voyage aux Terres australes, journal personnel du commandant Baudin. Imprimerie nationale, Paris.

Bonpland, A. (1812-1817). Description des plantes rares cultivées à Malmaison et à Navarre. Paris.
Bungener, P. (2008). Un botaniste dans la République des Sciences: Augustin-Pyramus de Candolle et ses correspondants scientifiques. Dix-Huitième Siècle 40: 153-171.

Burdet, H.M. (1979). Cartulae ad botanicorum graphicem. XV. Candollea 34 : 167-218.

Burdet, H.M., H. Greppin \& R. Spichiger (1990). Le développement de la Botanique à Genève. Bot. Helv. 100 : 273-292.

Candolle, A.P. DE (1809). Eloge historique de Mr Auguste Broussonet. Montpellier.

Candolle, A.P. de (1828). Mesembryanthemum. In: Candolle, A.P. DE (ed.), Prodr. 3: 415-450.

Catalogue des Herbiers de Genève [CHG] (2017). Base de donnés des herbiers en ligne du Conservatoire et Jardin botaniques de la Ville de Genève [http://www.ville-ge.ch/musinfo/bd/cjb/chg/ index.php?lang=en].

Clemants, S.E. (1995). Bejaria Mutis ex L. Fl. Neotropica 66: 54-106.

Cullen, J. (1965). Fibigia Medik. In: Davies, P.H. (ed.), Fl. Turkey $1: 356-358$.

Cuvier, G. (1806). Eloge historique de Jacques-Martin Cels. Mém. Cl. Sci. Math. Inst. France 7 : 139-158.

Cuvier, G. (1809). Eloge historique de M. Ventenat. Mém. Cl. Sci. Math. Inst. France 9: 97-108.

Davidse, G., M. Sousa Sánchez, S. Knapp \& F. Chiang Cabrera (2015). Saururaceae a Zygophyllaceae. In: Davidse, G. et al. (ed.), Fl. Mesoamer. 2(3).

Dehgan, B. (2012). Jatropha (Euphorbiaceae). Fl. Neotrop. Monogr. 110.

Delessert, S., J. Hottinguer, M. Delessert \& F. Bartholdi (1869). Lettre addressée au Conseil Municipal de Genève. Mém. Séances Cons. Munic. Ville Genève 25ème année: 311.

Deleuze, J.-P.F. (1804). Notice historique sur André Michaux. Ann. Mus. Natl. Hist. Nat. 3 : 191-227.

Firenze Herbarium Database (2017). Museo di Storia Naturale Sezione Botanica "F. Parlatore". Università degli studi di Firenze [http://parlatore.msn.unifi.it/types/search.php].

Flicker, B.J. \& H.E. BAllard (2015). Afrohybanthus (Violaceae), a new genus for a distinctive and widely distributed Old World hybanthoid lineage. Phytotaxa $230: 39-53$.

Fryxell, P.A. (1969). The genus Cienfuegosia Cav. (Malvaceae). Ann. Missouri Bot. Gard. 56: 179-250.

Galera, A. (ed.) (2016). El Arca de Neé: plantas recolectadas por el botánico Luis Neé durante la Expedición Malaspina. Consejo Superior de Investigaciones Cientificas. Real Jardin Botanico, Madrid.

González Bueno, A. (2002). Antonio José Cavanilles (1745-1804). La pasión por la Ciencia. Fundación Jorge Juan, Madrid. 
Green, P.S. (1968). Revision of the genus Notelaea (Oleaceae). J. Arnold Arbor. 49: 333-369.

Guillaumin, M.A. (1910). Un membre méconnu de l'expédition à la recherche de la Pérouse : le jardinier Lahaie. Bull. Mus. Natl. Hist. Nat. $16:$ 356-358.

Guillaumin, M.A. (1922). Notice complémentaire sur le jardinier Delahaye (alias Lahaie). Bull. Mus. Natl. Hist. Nat. 28:109-110.

Guillemin, A.J. (1833). Notice sur les collections botaniques de M. Benjamin Delessert à Paris. Arch. Bot. 1: 466-471.

Hedge, I.C. (1982). Salvia L. In: Rechinger, K.H. (ed.), Fl. Iranica 150: 403-476.

Herrnstadt, I. \& C.C. Heyn (1971). Studies in Heptaptera (Umbelliferae) II : taxonomic revision. Notes Roy. Bot. Gard. Edinburgh 31:91-107.

Hilliard, O.M. (1999). The tribe Selagineae (Scrophulariaceae). Royal Botanic Gardens, Kew.

Horton, J.H. (1963). A taxonomic revision of Polygonella (Polygonaceae). Brittonia 15 : 177-203.

Huber-Morath, A. (1981). Verbascum. In : Rechinger, K.H. (ed.), Fl. Iranica 147 : 5-51.

IPNI (2017). The International Plant Names Index [http://www.ipni. org].

Johnson, L.A.S. (1982). Notes on Casuarinaceae II. J. Adelaide Bot. Gard. 6: 73-87.

Jongkind, C.C.H. (1999). Combretaceae. In : Morat, P. (ed.), Fl. Gabon 35.

JSTOR Global Plants (2017). [http://plants.jstor.org].

Kodela, P.G. \& P.G. Wilson (2017). Lectotypification of Mimosa pubescens Vent. (Fabaceae, Mimosoideae). Telopea 20: 29-33.

LA Billardière, J.J.H. DE (1800). Relation du voyage à la recherche de la Pérouse 1. Paris.

La Billardière, J.J.H. De (1804-1805). Novae Hollandiae Plantarum Specimen 1. Paris.

Lack, H.W. (1980). Pulicaria. In: Rechinger, K.H (ed.), Fl. Iranica $145: 112-119$.

Lack, H.W. (2004). Jardin de la Malmaison - Empress Josephine's Garden. Prestel.

LAMY, D. (2008). Le dessin botanique dans la transmission des connaissances. In: Allain, Y.-M. (ed.), Passions botaniques: 139-156. Editions Ouest-France.

Lamy, D. (2013). Histoire de l'herbier - le voyage des collections dans le Jardin des Plantes de 1635 à 2013. In: Grenon, T. (ed.) L'herbier du Muséum. L'aventure d'une collection: 9-25. Artlys and Muséum national d'histoire naturelle.
Lavin, M. (1992). Biogeography and systematics of Poitea (Leguminosae). Syst. Bot. Monogr. 37.

LAWALrée, A. (1996). Ouvrages publiés ou illustrés par Pierre-Joseph Redouté. In: Dierkens, A. \& J.-M. Duvosquel (ed.), SaintHubert en Ardenne. Art - Histoire - Folklore 7 : 73-91.

Legée, G. (1977). Etienne Pierre Ventenat (1757-1808), botaniste limousin, face aux problèmes de classification et de séxualité végétales. Compt. Rend. Congr. Natl. Soc. Savantes, Sect. Sci. 102(3): 33-46.

L'Héritier de Brutelle, C.L. (1785-1786). Stirpes novae aut minus cognitae. Paris.

Liben, L. (1983). Combretacées. In: Satabié, B. (ed.), Fl. Cameroun 25.

Lin, Q. (2000). Taxonomic notes on the genus Illicium Linn. Acta Phytotax. Sin. 38: 167-181.

Lohmann, L.G. (2008). Bignoniaceae. In: Нотch кe, O., P. Berry \& O. Huber (ed.), Nuevo Catalogo de la Flora Vascular de Venezuela: 270-278. Fundacion Instituto Botánico de Venezuela, Caracas.

Lohmann, L.G. \& C.M. Taylor (2012). A New Generic Classification of Tribe Bignonieae (Bignoniaceae). Ann. Missouri Bot. Gard. 99: 348-489.

López Piñero, J.M. (2004). La obra botánica de Cavanilles. In: Antonio José Cavanilles. Segundo centenario de la muerte de un gran botánico: 11-146. Sociedad Económica de Amigos del País, Valencia.

Marquete, R. \& V. de F. Mansano (2012). Taxonomic Revision of the Casearia ulmifolia Complex (Salicaceae). Novon 22: 196-206.

Masson, F. (1913). L'Impératrice Joséphine et l'acclimatation à Malmaison. Bull. Soc. Acclim. France 60: 230-248.

McNeill, J.M., F.R. Barrie, W.R. Buck, V. Demoulin, W. Greuter, D.L. Hawksworth, P.S. Herendeen, S. Knapp, K. Marhold, J. Prado, W.F. Prud'Homme van Reine, G.F. Smith, J.H. Wiersema \& N.J. Turland (2012). International Code of Nomenclature for algae, fungi and plants (Melbourne Code) adopted by the Eighteenth International Botanical Congress Melbourne, Australia, July 2011. Regnum Veg. 154.

Menemen, Y. \& S.L. Jury (2001). Taxonomic studies on the genus Zosima Hoffm. (Umbelliferae). Ann. Naturbist. Mus. Wien 103: 557-571.

Michaux, A. (1803). Flora Boreali-Americana. 2 vol. Paris.

Moura, M., M.A. Carine, V. Malécot, P. Lourenço, H. Schaefer \& L. Silva (2015). A taxonomic reassessment of Viburnum (Adoxaceae) in the Azores. Phytotaxa 210: 4-23.

Muñoz Garmendia, F. (2001). La botánica y los botánicos de la expedición Malaspina, Luis Neé y Tadeo Haenke. In: SAN Pio, P. (ed.), La armonía natural. La naturaleza en la expedición marítima de Malaspina y Bustamante (1789-1794): 63-82. Lunwerg Editores. 
Nicolson, D.H. (2006). (1720) Proposal to conserve the name Caladium (Araceae) with a conserved type. Taxon 55:529-530.

Nussac, L. DE (1930). L'Impératrice Joséphine naturaliste et le Limousin P.-E. Ventenat. Rev. Sci. Limousin 16:173-177.

O’Leary, N., M.E. Múlgura \& O. Morrone (2010). Revisión Taxonómica de las Especies del Género Verbena (Verbenaceae). II: Serie Verbena. Ann. Missouri Bot. Gard. 97: 365-424.

Plant List (2017). Version 1.1 [http://www.theplantlist.org].

Portères, R. (1964). Histoire des Sciences: l'origine des appellations «Phanérogamie et plantes phanérogames». J. Agric. Trop. Bot. Appl. 11: 473-479.

Ramsay, D. (1858). The history of South Carolina, from its first settlement in 1670 to the year 1808 . Charleston.

Rasmussen, H.N. (1979). The genus Knowltonia (Ranunculaceae). Opera Bot. 53.

Rechinger, K.H. \& H. Schimann-Czeika (1965). Campanulaceae. In: Rechinger, K.H. (ed.), Fl. Iranica 13.

Rheede, H.A. van (1689). Hortus Indicus Malabaricus 9. Amsterdam.

Riedel, M. \& T. Riedel (2010). Der 'Kamelien-Seidel' war geschickt und originell. Dresdner Universitätsjournal 21(5): 4.

Robson, N.K.B. (1996). Studies in the genus Hypericum L. (Guttiferae) 6. Sections 20. Myriandra to 28. Elodes. Bull. Nat. Hist. Mus. Lond. (Bot.) 26 : 75-217.

Ross, J.H. (1982). A revision of the genus Templetonia R. Br. (Papilionaceae). Muelleria 5:1-29.

Rowley, G.D. (1956). Pierre-Joseph Redouté - "Raphael of the succulents". Cact. Succ. J. Gr. Brit. 18: 1-20.

Ruiz, L.H. \& J.A. Pavon (1798-1802). Flora Peruvianae, et Chilensis. 3 vol. Madrid.

SANDERs, R.W. (2006). Taxonomy of Lantana sect. Lantana (Verbenaceae): I. Correct application of Lantana camara and associated names. Sida 22 : 381-421.

Schuster, T.M., J.L. Reveal \& K.A. Kron (2011). Phylogeny of Polygoneae (Polygonaceae: Polygonoideae). Taxon 60: 1653-1666.

Short, P.S. (1979). Apium L. sect. Apium (Umbelliferae) in Australia.J. Adelaide Bot. Gard. 1: 205-235.

Sleumer, H. (1980). Flacourtiaceae. Fl. Neotropica 22.

Sleumer, H. \& J. Bosser (1980). Flacourtiacées. In: Bosser, J. et al. (ed.), Fl. Mascareignes 42.

Sonnerat (2017). Base de données des collections du Muséum national d'Histoire naturelle. MNHN, Paris [http://science.mnhn.fr/ institution/mnhn/collection/p/item/search/form].

Stafleu, F.A. (1966). Redouté and His Circle. In: Buckman, T.R. (ed.), Bibliography \& natural History: 46-65. University of Kansas Libraries, Lawrence.
Stafleu, F.A. \& R.S. Cowan (1986). Taxonomic literature. A selective guide to botanical publications and collections with dates, commentaries and types 6, ed. 2. Regnum Veg. 115.

STEARn, W.T. (1939). Ventenat's «Description des plantes ... de J.M. Cels», «Jardin de la Malmaison» and «Choix des plantes».J. Soc. Bibl. Nat. Hist. 1: 199-201.

Stearn, W.T. (1942). Bonpland's «Description des plantes rares cultivées à Malmaison et à Navarre».J. Arnold Arb. 23 : 110-111.

Stearn, W.T. (1970). Ventenat's «Decas generum novarum». Regnum Veg. $71: 342-352$.

Stearn, W.T. (1988). James Edward Smith (1759-1828): first President of the Linnean Society and his herbarium. Bot. J. Linn. Soc. 96: 199-216.

Sylvestre, M. (1806). Discours pronouncéà Montrouge le 16 mai 1806 lors de l'inhumation de J.-P.-M. Cels. Paris.

Tantra, I.G.M. (1976). A revision of the genus Sterculia L. in Malesia (Sterculiaceae). Forest Research Institute, Bogor.

Thompson, I.R. (2012). A revision of eastern Australian Bossiaea (Fabaceae: Bossiaeeae). Muelleria 29: 154-171.

Thompson, J. (1989). A revision of the genus Leptospermum (Myrtaceae). Telopea 3 : 301-449.

Tortosa, R.D. (1992). El complejo Retanilla-Talguenea-Trevoa (Rhamnaceae). Darwiniana 31:223-252.

Turland, N.J. (2013). The Code decoded. A user's guide to the International Code of nomenclature for algae, fungi, and plants. Regnum Veg. 155.

Ventenat, P.-E. (1792). Sur les parties des mousses qui ont été regardées comme fleurs mâles ou fleurs femelles. J. Hist. Nat. 1: 269-288.

Ventenat, P.-E. (1793). Nouveau genre. Bull. Sci. Soc. Philom. Paris $1: 65-67$.

Ventenat, P.-E. (1797). Muflier. Antirrhinum. In: Lamarck, J.B. (ed.), Encycl. 4: 347-366.

Ventenat, P.-E. (1799a). Tableau du règne végétale selon la méthode de Jussieu. 4 vol. Paris.

Ventenat, P.-E. (1799b). Dissertation sur le genre Dalea. Mém. Soc. Hist. Nat. Paris 1:111-113.

Ventenat, P.-E. (1800). Monographia del genero Tilia. Anales Hist. Nat. 2: 57-71.

Ventenat, P.-E. (1800-1803). Descriptions des plantes nouvelles et peu connues cultivées dans le jardin de J. M. Cels. Paris.

Ventenat, P.-E. (1801). Dissertation sur le genre Arum. Mag. Encycl. 4: 461-472.

Ventenat, P.-E. (1803-1805). Jardin de Malmaison. 2 vol. Paris. 
Ventenat, P.-E. (1803-1808). Choix de plantes: dont la plupart sont cultivées dans le jardin de Cels. Paris.

Ventenat, P.-E. (1807). Notice sur les plantes qui seront publiées dans les cinq dernières livraisons de l'ouvrage intitulé Choix de plantes. Mém. Cl. Sci. Math. Inst. Natl. France 8(1): 1-20.

Ventenat, P.-E. (1808a). Decas Generum novarum aut parum cogniturum. Paris.

Ventenat, P.-E. (1808b). Catalogue des livres de la bibliothèque de feu M. E.P. Ventenat, botaniste de Sa Majesté l'Impératrice et Reine. Paris.
Ventenat, P.-E. (1808c). Observations sur la famille à laquelle il faut rapporter les genres Samyda et Casearia. Description de quelques espèces nouvelles de ces deux genres. Mém. Cl. Sci. Math. Inst. Natl. France 8: 142-155.

VERdcourt, B. (1989). The identity of Clerodendrum manettii Vis. (Verbenaceae). Kew Bull. 44: 695-696.

VIANO, J. (1978). Les linaires à graines aptères du basin méditerranéen occidental. 1. Linaria sect. Versicolores. Candollea 33 : 43-88.

WCSP (2017). World Checklist of Selected Plant families. Facilitated by the Royal Botanic Gardens, Kew [http://apps.kew.org/wcsp/ home.do].

Williams, R.L. (2001). Botanophila in eighteenth-century France: the spirit of the Enlightenment. Kluwer Academic.

Appendix I. - Generic names cited by Ventenat between 1800 and 1808 in Descriptions, Choix and Jardin de Malmaison including their current status (see p. 95).

\begin{tabular}{|c|c|c|c|}
\hline Genus & Family & Reference & Current status \\
\hline Bossiaea Vent. & Leguminosae & Descr. PI. Nouv.: tab. 7. 1800 & accepted [nom. cons.] \\
\hline Caladium Vent. & Araceae & Descr. PI. Nouv.: tab. 30. 1801 & accepted [nom. cons.] \\
\hline Calomeria Vent. & Asteraceae & Jard. Malmaison 2: tab. 73. 1804 & accepted \\
\hline Chaptalia Vent. & Asteraceae & Descr. PI. Nouv.: tab. 61. 1802 & accepted [nom. cons.] \\
\hline Corydalis Vent. & Papaveraceae & Choix PI.: tab. 19. 1803 & nom. rejic. against Corydalis DC. \\
\hline Gothofreda Vent. & Apocynaceae & Choix PI.: tab. 60. 1808 & nom. rejic. against Oxypetalum $\mathrm{R}$. Br. \\
\hline Nemesia Vent. & Scrophulariaceae & Jard. Malmaison 1: tab. 41. 1804 & accepted \\
\hline Notelaea Vent. & Oleaceae & Choix Pl.: tab. 25. 1804 & accepted \\
\hline Nycterium Vent. & Solanaceae & Jard. Malmaison 2: tab. 85. 1805 & accepted, syn. of Solanum L. \\
\hline Oliveria Vent. & Apiaceae & Descr. PI. Nouv.: tab. 21. 1801 & accepted \\
\hline Phebalium Vent. & Rutaceae & Jard. Malmaison 2: tab. 102. 1805 & accepted \\
\hline Poiretia Vent. & Leguminosae & Choix PI.: tab. 42. 1807 & accepted [nom. cons.] \\
\hline Poitea Vent. & Leguminosae & Choix PI.: tab. 36. 1807 & accepted \\
\hline Pongamia Vent. & Leguminosae & Jard. Malmaison 1: tab. 28. 1803 & nom. rejic. against Millettia Wight \& Arn. \\
\hline Redoutea Vent. & Malvaceae & Descr. PI. Nouv.: tab. 11. 1800 & accepted \\
\hline Riedlea Vent. & Malvaceae & Choix PI.: tab. 37. 1807 & [nom. illeg.] [non Riedlea Mirb.] \\
\hline Turpinia Vent. & Staphyleaceae & Choix PI.: tab. 31. 1807 & accepted [nom. cons.] \\
\hline Villarsia Vent. & Menyanthaceae & Choix Pl.: tab. 9. 1803 & accepted [nom. cons.] \\
\hline
\end{tabular}


Appendix II. - Exhaustive list of the 343 names dealt with in Ventenat's three flower books: Descriptions, Choix and Jardin de Malmaison. Bold numbers in brackets refer to the "lectotypifications and notes" section; regions in bold and small capitals are the one used in Fig. 7 (see p. 95, 105); if typification is based on a cultivated specimen, geographical origin is indicated in square brackets. Abbreviations: HT: holotype; LT: lectotype; ILT: isolectotype; NT: neotype; OM: original material.

Acbillea aspleniifolia Vent. (Asteraceae), Descr. P1. Nouv.: tab. 95. 1803. NoRTH AMERICA: LT: G; OM: G (1). = Achillea millefolium L.

Acbillea imbricata Vent. (Asteraceae), Descr. P1. Nouv.: tab. 54. 1801. WeSTERN AsIA: Orient, Bruguière \& Olivier s.n. HT: G [G00341438]. = Achillea membranacea (Labill.) DC.

Agyneia impubes L. (Euphorbiaceae), Descr. P1. Nouv.: tab. 23. 1801. CHINA. = Glochidion puberum (L.) Hutch.

Allium fragrans Vent. (Amaryllidaceae), Descr. P1. Nouv.: tab. 26. 1801. [NoRTH Africa]: "envoyé de Montpellier", Ventenat s.n. HT: G [G00341468]. = Nothoscordum gracile (Aiton) Stearn

Alyssum mutabile Vent. (Brassicaceae), Descr. P1. Nouv.: tab. 85. 1802. [WESTERN AsIA]: Hort. Cels, Ventenat s.n. LT: G; ILT: G (2). $\equiv$ Berteroa mutabilis (Vent.) DC.

Amsonia angustifolia (Aiton) Michx. (Apocynaceae), Choix P1.: tab. 29. 1804. NORTH AMERICA. $=$ Amsonia ciliata Walter

Anagallis fruticosa Vent. (Primulaceae), Choix Pl.: tab. 14. 1803. North AFrica: LT: G; ILT: B-W, G-DC; OM: G-DC (3). = Anagallis monelli L.

Anamenia coriacea Vent. (Ranunculaceae), Jard. Malmaison 1: tab. 22. 1803. [South Africa]: LT (designated by Rasmussen, 1979: 27): P-JU; ILT: G, G-DC (4). = Anemone versicatoria (L. f.) Prantl.

Anamenia gracilis Vent. (Ranunculaceae), Jard. Malmaison 1: sub tab. 22. 1803. South Africa: Cape, Thunberg s.n. LT (designated by Rasmussen, 1979: 16): P-JU n 10575 [P00667196]. = Anemone knowltonia Burtt Davy

Ancistrum repens Vent. (Rosaceae), Descr. Pl. Nouv.: tab. 6. 1800. [SouTH Africa]: LT: G; OM: G, P-JU (5). = Acaena ovalifolia Ruiz \& Pav.

Andreusia debilis (Andrews) Vent. (Myoporaceae), Jard. Malmaison 2: sub tab. 108. 1805. Australia. $\equiv$ Eremophila debilis (Andrews) Chinnock

Andreusia glabra (Andrews) Vent. (Myoporaceae), Jard. Malmaison 2: tab. 108. 1805. Australia. $=$ Myoporum boninense subsp. australe Chinnock

Andromeda anastomosans Mutis ex L.f. (Ericaceae), Choix P1.: tab. 53. 1808. Central AMERICA. $\equiv$ Gaultheria anastomosans (Mutis ex L. f.) Kunth

Andromeda calyculata var. anomala Vent. (Ericaceae), Jard. Malmaison 2: sub tab. 80. 1804. [NoRTH AMERICA]: Hort. Cels, Ventenat s.n. HT: G [G00341523]. = Chamaedaphne calyculata $(\mathrm{L}$.$) Moench$

Andromeda cassinefolia Vent. (Ericaceae), Descr. P1. Nouv.: tab. 60. 1802. [NorTH AMERICA]: LT: G; OM: G (6). = Zenobia pulverulenta (W. Bartram ex Willd.) Pollard

Andromeda cassinefolia var. nuda Vent. (Ericaceae), Jard. Malmaison 2: tab. 79. 1804 [nom. inval.]. NORTH AMERICA. $=$ Zenobia pulverulenta $(\mathrm{W}$. Bartram ex Willd.) Pollard

Andromeda cassinefolia var. pulverulenta Vent. (Ericaceae), Jard. Malmaison 2: tab. 79. 1804 [nom. inval.]. NORTH AMERICA. = Zenobia pulverulenta $(\mathrm{W}$. Bartram ex Willd.) Pollard

Andromeda ferruginea Walter (Ericaceae), Jard. Malmaison 2: tab. 80. 1804. NORTH AMERICA. $\equiv$ Lyonia ferruginea (Walter) Nutt.

Andropogon schoenanthus L. (Poaceae), Descr. P1. Nouv.: tab. 89. 1802. INDIA. $\equiv$ Cymbopogon schoenanthus (L.) Spreng.

Antirrbinum bipartitum Vent. (Plantaginaceae), Descr. P1. Nouv.: tab. 82. 1802. [NORTH AFrICA]: LT (first step designated by Viano, 1978: 79; second step designated here): G; ILT: G; OM: G-DC (7). = Linaria incarnata (Vent.) Spreng.
Antirrbinum canadense L. (Plantaginaceae), Descr. P1. Nouv.: tab. 49. 1801. NORTH AMERICA. $\equiv$ Nuttallanthus canadensis (L.) D.A. Sutton

Antirrbinum triornithophorum L. (Plantaginaceae), Jard. Malmaison 1: tab. 11. 1803. NORTH AMERICA. $\equiv$ Linaria triornithophora $($ L.) Cav.

Apium prostratum Labill. ex Vent. (Apiaceae), Jard. Malmaison 2: tab. 81. 1804 [AUSTRALIA]: LT: G; ILT: G-DC (8).

Aralia hispida Vent. (Araliaceae), Descr. P1. Nouv.: tab. 41. 1801. NorTH AMERICA: Illinois, Michaux s.n. HT: G [G00236894]; IT: P-MICH [P00667164, P00667167, P00667170].

Ardisia crenulata Vent. (Myrsinaceae), Choix P1.: tab. 5. 1803. West INDIEs: HT: G; IT: G, P-JU (9). „ Parathesis crenulata (Vent.) Hook. f. ex Hemsl.

Arenaria montana L. (Caryophyllaceae), Descr. P1. Nouv.: tab. 34. 1801. Europa.

Ascyrum stans Michx. ex Willd. (Hypericaceae), Jard. Malmaison 2: tab. 90. 1805. NORTH AMERICA.

Asperula brevifolia Vent. (Rubiaceae), Descr. P1. Nouv.: tab. 63. 1802. [WeSTERN AsIA]: Hort. Cels, Ventenat s.n. HT: G [G00341455].

Aster filifolius Vent. (Asteraceae), Jard. Malmaison 2: tab. 82. 1804. [SoutH AFrICA]: Ventenat s.n. HT: G [G00341483]. झ Felicia filifolia (Vent.) Burtt Davy

Aster microphyllus Vent. (Asteraceae), Jard. Malmaison 2: sub tab. 82. 1804. AUSTRALIA: L. Ventenat s.n. HT: G [G00301085]. = Olearia microphylla (Vent.) Maiden \& Betche

Aster sericeus Vent. (Asteraceae), Descr. P1. Nouv.: tab. 33.1801. [NORTH AMERICA] : Hort. Cels, Ventenat s.n. HT: G [G00341481]. = Symphyotrichum sericeum (Vent.) G.L. Nesom

Banisteria parvifolia Vent. (Malpighiaceae), Choix P1.: tab. 51. 1808. WEST INDIES: St. Thomas, Riedlé s.n. HT: G [G00352869]. = Heteropterys purpurea (L.) Kunth

Banisteria tiliifolia Vent. (Malpighiaceae), Choix P1.: tab. 50. 1808. InDonesia: Java, Lahaye s.n. HT: G [G00352955]. = Stigmaphyllon albidum (Blume) C.E. Anderson

Bauera rubioides Andrews (Cunoniaceae), Jard. Malmaison 2: tab. 96. 1805. Australia.

Bejaria racemosa Vent. (Ericaceae), Descr. P1. Nouv.: tab. 51. 1801. NorTH America: LT (designated by Clemants, 1995: 71): G; ILT: G, P, P-MICH; OM: G-DC (10).

Bejaria resinosa Mutis ex L. f. (Ericaceae), Choix P1.: tab. 52. 1808. SoutH AFrica.

Bignonia pandorea Vent. (Bignoniaceae), Jard. Malmaison 1: tab. 43. 1804 [nom. inval.]. NoRfolk IsLAND. $=$ Pandorea pandorana (Andrews) Steenis

Blackwellia cerasifolia Vent. (Salicaceae), Choix P1.: tab. 56. 1808. MADAGASCAR: Commerson s.n. HT: G [G00364811]; IT: P [P00346105], P-JU n 14405 [P00667194]. $\equiv$ Calantica cerasifolia (Vent.) Tul.

Blackwellia glauca Vent. (Salicaceae), Choix P1.: tab. 55. 1808. Mascarene IsLANDS: Mauritius, Commerson s.n. LT (designated by Sleumer \& Bosser 1980: 10): G [G00364329]; OM: P-JU n 14409 [P00667195]. = Homalium integrifolium (Lam.) Baill.

Blackwellia tomentosa Vent. (Salicaeae), Choix P1.: tab. 57. 1808. Indonesia: Java, Lahaye s.n. HT: G [G00364374]. = Homalium tomentosum (Vent.) Benth.

Borago crassifolia Vent. (Boraginaceae), Descr. P1. Nouv.: tab. 100. 1803. [WESTERN AsIA]: Hort. Cels, Ventenat s.n. HT: G [G00341533]. = Caccinia macranthera var. crassifolia (Vent.) C. Koch 
Boronia pinnata Sm. (Rutaceae), Jard. Malmaison 1: tab. 38. 1804. AuSTRALIA.

Bossiaea heterophylla Vent. (Leguminosae), Descr. P1. Nouv.: tab. 7. 1800. [AusTralia]: Hort. Cels, Ventenat s.n. HT: G [G00341556].

Bumelia reclinata (Michx.) Vent. (Sapotaceae), Choix P1.: tab. 22. 1803. NoRTH AMERICA. $\equiv$ Sideroxylon reclinatum Michx.

Bunias spinosa L. (Brassicaceae), Jard. Malmaison 1: tab. 16. 1803. NorTH AFRICA. $\equiv$ Zilla spinosa (L.) Prantl.

Buphthalmum flosculosum Vent. (Asteraceae), Descr. P1. Nouv.: tab. 25. 1801. Western Asia: LT (designated by Anderberg 1982: 301): G [G00222326]; OM: G-BOIS [G00330747], G-DC [G00468533], P [P02274995, P02274996]. = Anvillea garcinii (Burm. f.) DC.

Caladium arborescens (L.) Vent. (Araceae) in Mag. Encycl. 4: 471. 1801 [cited in Descr. P1. Nouv.: sub tab. 30. 1801]. SOUTH AMERICA. $\equiv$ Montrichardia arborescens (L.) Schott

Caladium auritum (L.) Vent. (Araceae) in Mag. Encycl. 4: 472.1801 [cited in Descr. P1. Nouv.: sub tab. 30. 1801]. WEST INDIES. = Syngonium auritum (L.) Schott

Caladium bicolor (Aiton) Vent. (Araceae) in Mag. Encycl. 4: 464. 1801 [cited in Descr. P1. Nouv.: tab. 30. 1801]. SouTH AMERICA.

Caladium esculentum (L.) Vent. (Araceae) in Mag. Encycl. 4: 471. 1801 [cited in Descr. P1. Nouv.: sub tab. 30. 1801]. WEST InDIES. $\equiv$ Colocasia esculenta (L.) Schott

Caladium helleborifolium (Jacq.) Vent. (Araceae) in Mag. Encycl. 4: 471. 1801 [cited in Descr. P1. Nouv.: sub tab. 30. 1801]. South America. $\equiv$ Xanthosoma helleborifolium (Jacq.) Schott

Caladium nymphaeifolium Vent. (Araceae) in Mag. Encycl. 4: 471. 1801 [cited in Descr. P1. Nouv.: sub tab. 30. 1801]. [INDONESIA]: LT: (Rheede, Hort. Malab. 9: tab. 22. 1689) (11). = Colocasia esculenta (L.) Schott

Caladium ovatum (L.) Vent. (Araceae) in Mag. Encycl. 4: 471. 1801 [cited in Descr. P1. Nouv.: sub tab. 30. 1801]. INDIA. = Lagenandra ovata (L.) Thwaites

Caladium seguinum (Jacq.) Vent. (Araceae) in Mag. Encycl. 4: 471.1801 [cited in Descr. P1. Nouv.: sub tab. 30. 1801]. WEST INDIES. = Dieffenbachia seguine (Jacq.) Schott

Calendula chrysanthemifolia Vent. (Asteraceae), Jard. Malmaison 1: tab. 56. 1804 [SOUTH AFRICA]: LT: G; ILT: G (12). = Dimorphotheca chrysanthemifolia (Vent.) DC.

Calendula flaccida Vent. (Asteraceae), Jard. Malmaison 1: tab. 20. 1803. [SouTH AFricA]: Hort. Malmaison, Ventenat s.n. HT: G [G00341492]. = Dimorphotheca tragus (Aiton) B. Nord.

Callistachys elliptica Vent. (Leguminosae), Jard. Malmaison 2: sub tab. 115. 1805. [AuSTRALIA]: Hort. Malmaison, Ventenat s.n. HT: G [G00370535]. $\equiv$ Oxylobium ellipticum (Vent.) R. Br.

Callistachys lanceolata Vent. (Leguminosae), Jard. Malmaison 2: tab. 115. 1805. [Australia]: Hort. Malmaison, Ventenat s.n. HT: G [G00370528]. $\equiv$ Oxylobium lanceolatum (Vent.) Druce

Calomeria amaranthoides Vent. (Asteraceae), Jard. Malmaison 2: tab. 73. 1804. [Australia]: Hort. Malmaison, Ventenat s.n. HT: G [G00341475]; IT: P-JU n 9211 [P006667165].

Campanula aurea L. f. (Campanulaceae), Jard. Malmaison 2: tab. 116. 1805. MADEIRA. $\equiv$ Musschia aurea (L. f.) Dumort

Campanula tomentosa Vent. (Campanulaceae), Descr. P1. Nouv.: tab. 18. 1800 [nom. illeg.] [non C. tomentosa Lam.]. [JAPAN]: Hort. Cels, Ventenat s.n. HT: G [G00236832]; IT: P-JU n 7650 [P00667161]. =Campanula celsii A. DC.

Campanula vinciflora Vent. (Campanulaceae), Jard. Malmaison 1: tab. 12. 1803 [nom. inval.]. NEW ZEALAND. = Wablenbergia gracilis (G. Forst.) A. DC.

Casearia comocladifolia Vent. (Salicaceae) in Mém. Cl. Sci. Math. Inst. Natl. France 8: 151. 1808 [cited in Choix P1. : sub tab. 44. 1808]. WeST INDIES : Dominican Republic / Haiti, Turpin \& Poiteau s.n. LT (designated by Sleumer 1980: 292): P-JU nº 16207 [P00678804]; ILT: G [G00364174]. = Casearia coriacea Vent.
Casearia coriacea Vent. (Salicaceae) in Mém. Cl. Sci. Math. Inst. Natl. France 8: 151. 1808 [cited in Choix P1. : tab. 45. 1808]. MASCARENE IsLANDS : Mauritius: Lahaye s.n. HT: G [G00355987] (see Sleumer 1980: 21).

Casearia fragilis Vent. (Salicaceae) in Mém. Cl. Sci. Math. Inst. Natl. France 8: 153. 1808 [cited in Choix P1. : sub tab. 47. 1808]. MAscarene IsLands: Reunion Island, Commerson s.n. HT: G [G00364737]; IT: P-JU nº 16219 [P00678837]. = Casearia coriacea Vent.

Casearia grewiifolia Vent. (Salicaceae) in Mém. Cl. Sci. Math. Inst. Natl. France 8: 154. 1808 [cited in Choix P1. : sub tab. 47. 1808]. INDONESIA: Java, Lahaye s.n. HT: G [G00364738].

Casearia ilicifolia Vent. (Salicaceae) in Mém. Cl. Sci. Math. Inst. Natl. France 8: 150. 1808 [cited in Choix Pl. : tab. 44. 1808]. WeST INDIES: Dominican Republic / Haiti, Turpin s.n. HT: G [G00364382].

Casearia stipularis Vent. (Salicaceae) in Mém. Cl. Sci. Math. Inst. Natl. France 8: 152. 1808 [cited in Choix P1. : tab. 46. 1808] [nom. inval.]. WEST INDIES. = Casearia arborea (Rich.) Urb.

Casearia tinifolia Vent. (Salicaceae) in Mém. Cl. Sci. Math. Inst. Natl. France 8: 154. 1808 [cited in Choix P1.: tab. 47. 1808]. MAsCARENE IsLANDS: Mauritius, Lahaye s.n. HT: G [G00165542] (see Sleumer 1980: 19).

Casearia ulmifolia Vahl ex Vent. (Salicaeae), Choix P1.: sub tab. 46. 1808. WEST INDIES: LT (first step designated by SLEumer, 1980: 324; second step designated here): C; ILT: BM, BR, C, G, L, P-JU (13).

Cassine xylocarpa Vent. (Celastraceae), Choix P1.: tab. 23. 1803. [WEST INDIEs]: LT (designated by Davidse, 2015: 214): G [G00341512]; OM: G [G00341513].

Castilleja coronopifolia Vent. (Scrophulariaceae), Choix P1.: tab. 59. 1808. South America: Santa Fe de Bogota, Umana s.n. HT: G [G00341529]. = Castilleja fissifolia $\mathrm{L}$. $\mathrm{f}$.

Casuarina distyla Vent. (Casuarinaceae), Descr. P1. Nouv.: tab. 62. 1802. [Australia]: HT: G; IT: NSW (14). = Allocasuarina distyla (Vent.) L.A.S. Johnson

Ceanothus discolor Vent. (Rhamnaceae), Jard. Malmaison 1: tab. 58. 1804. [Australia]: Hort. Cels, Ventenat s.n. HT: G [G00440927]. „P Pomaderris discolor (Vent.) Poir.

Celsia lanceolata Vent. (Scrophulariaceae), Descr. P1. Nouv.: tab. 27. 1801. [Western Asia]: LT: G; ILT: G-BOIS; OM: G-BOIS, P (15). = Verbascum assurense Bornm. \& Hand.-Mazz.

Centaurea alata Lam. (Asteraceae), Descr. P1. Nouv.: tab. 80. 1802. WESTERN AsIA. = Centaurea behen $\mathrm{L}$.

Centaurea prolifera Vent. (Asteraceae), Descr. P1. Nouv.: tab. 16. 1800. [NoRTH AfrICA]: Hort. Cels, Ventenat s.n. HT: G [G00341490]. = Centaurea glomerata Vahl

Centaurea pumila L. (Asteraceae), Jard. Malmaison 1: tab. 9. 1803. NoRTH AFricA.

Cestrum macrophyllum Vent. (Solanaceae), Choix P1.: tab. 18. 1803. West INDIES. Porto Rico: Riedlé s.n. HT: G [G00169748]; IT: P-JU nº 6460 [P00671368].

Chaptalia tomentosa Vent. (Asteraceae), Descr. P1. Nouv.: tab. 61. 1802. North America: Caroline, Bosc s.n. HT: G [G00341473]; IT: G-DC [G00499760], P-LAM [P00342940].

Cheiranthus linearis Vent. (Brassicaceae), Jard. Malmaison 2: sub tab. 83. 1804 [nom. illeg.] [non C. linearis Forssk.]. CANARY IsLANDs: LT: G; OM: G, G-DC (16). = Erysimum semperflorens (Schousb.) Wettst.

Cheiranthus longifolius Vent. (Brassicaceae), Jard. Malmaison 2: tab. 83. 1804. [CANARY IsLANDS]: LT: G; ILT: G-DC; OM: G, G-DC (17). = Erysimum beritieri Kuntze

Cheiranthus longipetalus Vent. (Brassicaceae), Descr. P1. Nouv.: tab. 93. 1803. [Western Asia]: Hort. Cels, Ventenat s.n. HT: G [G00371849]. $\equiv$ Mattbiola longipetala (Vent.) DC. 
Chironia decussata Vent. (Gentianaceae), Descr. P1. Nouv.: tab. 31. 1801. [SouTH AfRICA]: Hort. Cels, Ventenat s.n. HT: G [G00341507]. = Orphium frutescens (L.) E. Mey.

Chrysanthemum praealtum Vent. (Asteraceae), Descr. P1. Nouv.: tab. 43. 1801. Western Asia: LT: G; ILT: G; OM: G-DC (18). = Tanacetum parthenium (L.) Sch. Bip.

Cineraria cruenta Masson ex L'Hér. (Asteraceae), Jard. Malmaison 2: tab. 99. 1805. CANARY IsLANDS. $\equiv$ Pericallis cruenta (Masson ex L'Hér.) Bolle.

Cineraria hirsuta Vent. (Asteraceae), Jard. Malmaison 2: tab. 95. 1805. [SouTH AfricA]: Hort. Malmaison, Ventenat s.n. HT: G [G00341482]. = Felicia cymbalariae (Aiton) Bolus \& Wolley-Dod ex Adamson \& T.M. Salter

Cineraria populifolia L'Hér. (Asteraceae), Jard. Malmaison 2: tab. 100. 1805. CANary Islands. = Pericallis appendiculata (L. f.) B. Nord.

Cineraria ramentosa L'Hér. (Asteraceae), Jard. Malmaison 2: tab. 101. 1805. CANARY Islands. = Pericallis echinata (L. f.) B. Nord.

Cissus antarctica Vent. (Vitaceae), Choix P1.: tab. 21. 1803. [AuSTRALIA]: Hort. Cels, Ventenat s.n. HT: G [G00341435].

Cistus carolinianus Walter (Cistaceae), Descr. P1. Nouv.: tab. 74. 1802. NoRTH AMERICA. $\equiv$ Helianthemum carolinianum (Walter) Michx.

Citharexylum pentandrum Vent. (Verbenaceae), Descr. P1. Nouv.: tab. 47. 1801. [West Indies]: Hort. Cels, Ventenat s.n. HT: G [G00341486]. = Citharexylum spinosum L.

Clerodendrum viscosum Vent. (Lamiaceae), Jard. Malmaison 1: tab. 25. 1803. [INDONESIA]: LT: G; OM: G (19). = Clerodendrum infortunatum L.

Clethra arborea Aiton (Clethraceae), Jard. Malmaison 1: tab. 40. 1804. MADEIRA.

Clitoria heterophylla Lam. (Leguminosae), Choix P1.: tab. 26. 1804. MASCARENE ISLANDS.

Cneorum pulverulentum Vent. (Cneoraceae), Descr. P1. Nouv.: tab. 77. 1802. CANARY IsLANDS : Broussonet s.n. HT: G [G00236028]; IT: G [G00476956].

Colletia ephedra Vent. (Rhamnaceae), Descr. P1. Nouv.: sub tab. 92. 1803. South AMEricA: LT (first step designated by Tortosa, 1992: 235; second step designated here): P; ILT: G, G-DC, P, P-JU n ${ }^{\circ} 16153$ (20). $\equiv$ Retanilla ephedra (Vent.) Brongn.

Colletia obcordata Vent. (Rhamnaceae), Descr. P1. Nouv.: tab. 92. 1803. [SouTH AmERICA]: LT: G; ILT : G, G-DC, P-JU n 16157 (20). = Retanilla ephedra (Vent.) Brongn.

Colletia serratifolia Vent. (Rhamnaceae), Descr. P1. Nouv.: sub tab. 92.1803. SouTH AMERICA: Peru, Dombey s.n. HT: G [G00341566]; IT: P [P01818934, P01818935], P-JU n 16155 [P00678781]. = Discaria articulata (Phil.) Miers

Combretum aculeatum Vent. (Combretaceae), Choix P1.: sub tab. 58. 1808. WEST Africa. Senegal, Roussillon s.n. LT (designated by Liben, 1983: 23): P-JU $\mathrm{n}^{\circ} 13629$ [P00667185]; ILT: G-DC [G00656747], P [P00391705].

Combretum paniculatum Vent. (Combretaceae), Choix Pl.: sub tab. 58. 1808. WEST AFrICA: Senegal, Roussillon 60 LT (designated by Jongkind, 1999: 70): P-JU n` 13632 [P00667191 sheet 1, P00667192 sheet 2]; ILT: G-DC [G00656760].

Combretum trifoliatum Vent. (Combretaceae), Choix P1.: tab. 58. 1808. INDONESIA: Java, Lahaye s.n. HT: G [G00177911]; IT: P-JU nº 13633 [P00667189].

Conchium aciculare Sm. ex Vent. (Proteaceae), Jard. Malmaison 2: tab. 111. 1805. [Australia]: Hort. Malmaison, Ventenat s.n. HT: G [G00389593]. = Hakea sericea Schrad. \& J.C. Wendl.

Conchium dactyloides (Gaertn.) Vent. (Proteaceae), Jard. Malmaison 2: tab. 110. 1805. AUSTRALIA. $\equiv$ Hakea dactyloides (Gaertn.) Cav.

Convolvulus scoparius L. f. (Convolvulaceae), Choix P1.: tab. 24. 1803. CANARY ISLANDS. $\equiv$ Rhodorbiza scoparia (L. f. ) Webb \& Berthel.

Correa alba Andrews (Rutaceae), Jard. Malmaison 1: tab. 13. 1803. Australia.

Correa reflexa (Labill.) Vent. (Rutaceae), Jard. Malmaison 1: sub tab. 13. 1803. Australia.
Correa revoluta Vent. (Rutaceae), Jard. Malmaison 1: sub tab. 13.1803.AusTrALIA: HT: G; IT : MA (21). = Correa reflexa (Labill.) Vent.

Correa rufa (Labill.) Vent. (Rutaceae), Jard. Malmaison 1: sub tab. 13. 1803. AUSTRALIA. = Correa reflexa (Labill.) Vent.

Corydalis fungosa (Aiton) Vent. (Papaveraceae), Choix P1.: tab. 19. 1803. NorTH AMERICA. $\equiv$ Adlumia fungosa (Aiton) Britton, Sterns \& Poggenb.

Cotyledon crenata (Andrews) Vent. (Crassulaceae), Jard. Malmaison 1: tab. 49. 1804. WeST AFRICA. $\equiv$ Kalanchoe crenata (Andrews) Haw.

Crotalaria purpurea Vent. (Leguminosae), Jard. Malmaison 2: tab. 66. 1804. [SouTH AFrICA]: Hort. Malmaison, Ventenat s.n. HT: G [G00341553]. = Hypocalyptus coluteoides (Lam.) R. Dahlgren

Crotalaria semperflorens Vent. (Leguminosae), Descr. P1. Nouv.: tab. 17. 1800. [INDONESIA]: Hort. Cels, Ventenat s.n. HT: G [G00341563]. = Crotalaria verrucosa $\mathrm{L}$.

Croton hircinus Vent. (Euphorbiaceae), Jard. Malmaison 1: tab. 50. 1804. [WEST INDIEs]: Hort. Malmaison, Ventenat s.n. HT: G [G00341569].

Croton penicillatus Vent. (Euphorbiaceae), Choix P1.: tab. 12. 1803 [nom. inval.]. EUROPA. = Croton ciliatoglandulifer Ortega

Crowea saligna Andrews (Rutaceae), Jard. Malmaison 1: tab. 7. 1803. AustraliA.

Curatella alata Vent. (Dilleniaceae), Choix P1.: tab. 49. 1808. SouTH AMERICA: Guyana, Martin s.n. HT: G [G00237403 :]; IT: P [P00682188, P00682191, P00682192]. $\equiv$ Davilla alata (Vent.) Briq.

Cytisus proliferus L. f. (Leguminosae), Descr. P1. Nouv.: tab. 13. 1800. CANARY ISLANDS.

Dalea purpurea Vent. (Leguminosae), Descr. P1. Nouv.: tab. 40. 1801. NoRTH AMERICA: LT: G; ILT: P, P-MICH; OM: G (22).

Daviesia denudata Vent. (Leguminosae), Choix P1.: tab. 6. 1803 [nom. inval.] AUSTRALIA. = Viminaria juncea $($ Schrad. \& J.C. Wendl.) Hoffmanns.

Dianthus monadelphus Vent. (Caryophyllaceae), Descr. P1. Nouv.: tab. 39. 1801 [Western Asia]: LT: (Ventenat, Descr. P1. Nouv.: tab. 39. 1801) (23).

Dianthus procumbens Vent. (Caryophyllaceae), Descr. P1. Nouv.: index 1803 [nom. inval.]. WeSTERn ASIA. = Dianthus monadelphus Vent.

Dillenia volubilis (Andrews) Vent. (Dilleniaceae), Choix P1.: tab. 11. 1803. AUSTRALIA. $\equiv$ Hibbertia volubilis Andrews

Dionaea muscipula J. Ellis (Droseraceae), Jard. Malmaison 1: tab. 29. 1803. NORTH AMERICA.

Diosma cerefolia Vent. (Rutaceae) Jard. Malmaison 2: tab. 93. 1805. [SouTH AFrICA]: LT: G; ILT: G-DC (24). = Agathosma cerefolia (Vent.) Bartl. \& H.L.Wendl.

Diosma hirta Lam. (Rutaceae), Jard. Malmaison 2: tab. 72. 1804. SouTH AFricA. = Agathosma corymbosa (C.V. Montin) G. Don.

Diosma serratifolia Curtis (Rutaceae), Jard.Malmaison 2: tab. 77.1804.AuSTRALIA. = Agathosma serratifolia (Curtis) Spreeth.

Dracocephalum variegatum Vent. (Lamiaceae), Descr. P1. Nouv.: tab. 44. 1801 [nom. inval.]. NORTH AMERICA. = Physostegia virginiana subsp. praemorsa (Shinners) P.D. Cantino

Echium giganteum L. f. (Boraginaceae), Jard. Malmaison 2: tab. 71. 1804. CANARY IsLANDS.

Echium grandiflorum Andrews (Boraginaceae), Jard. Malmaison 2: tab. 97. 1805. SOUTH AFRICA. = Lobostemon regulariflorus (Ker Gawl.) Buys

Echium thyrsoideum Juss. ex Vent. (Boraginaceae), Jard. Malmaison 2: sub tab. 97. 1805. EUROPA : LT : P-JU (25). = Echium maculatum L

Elaeodendron australe Vent. (Celastraceae), Jard. Malmaison 2: tab. 117. 1805. [Australia]: Hort. Malmaison, Ventenat s.n. HT: G [G00177239]. $\equiv$ Cassine australis (Vent.) Kuntze

Embothrium salicifolium Vent. (Proteaceae), Descr. P1. Nouv.: tab. 8. 1800. [Australia]: Hort. Cels, Ventenat s.n. HT: G [G00389595]. $\equiv$ Hakea salicifolia (Vent.) B.L. Burtt 
Epilobium tomentosum Vent. (Onagraceae), Descr. P1. Nouv.: tab. 90. 1802. [Western AsIA]: LT: G; probable ILT: G-DC (26). = Epilobium hirsutum L.

Erica lageniformis Salisb. (Ericaceae), Jard. Malmaison 1: tab. 33. 1804. SouTH AFrICA.

Erucaria aleppica Gaertn. (Brassicaceae), Descr. P1. Nouv.: tab. 64. 1802. WESTERN AsIA. = Erucaria hispanica $($ L.) Druce

Escallonia discolor Vent. (Escalloniaceae), Choix P1.: tab. 54. 1808. SouTH AMERICA: Santa-Fe de Bogota, Umana s.n. HT: G [G00341551].

Eupatorium ayapana Vent. (Asteraceae), Jard. Malmaison 1: tab. 3. 1803. [SouTH AMERICA]: LT: G; ILT: G-DC; OM: G (27). = Ayapana triplinervis (Vahl) R.M. King \& H. Rob.

Eupatorium speciosum Vent. (Asteraceae), Descr. P1. Nouv.: tab. 79. 1802 [nom. inval.]. NORTH AMERICA. = Liatris elegans (Walter) Michx.

Euphorbia mellifera Aiton (Euphorbiaceae), Jard. Malmaison 1: tab. 30. 1803. Madeira.

Ficus rubiginosa Desf. ex Vent. (Moraceae), Jard. Malmaison 2: tab. 114. 1805. [AuSTRALIA]: Hort. Malmaison, Ventenat s.n. HT: G [G00341461].

Gaultheria erecta Vent. (Ericaceae), Descr. P1. Nouv.: tab. 5. 1800. SouTH America: Santa-Fe de Bogota, Goudot s.n. HT: G [G00352077]; IT: L [L0007087].

Gnaphalium diosmifolium Vent. (Asteraceae), Jard. Malmaison 2: tab. 74. 1804. [SouTh AFricA]: Hort. Malmaison, Ventenat s.n. HT: G [G00301225]. $\equiv$ Ozothamnus diosmifolius (Vent.) DC.

Goodenia ovata Sm. (Goodeniaceae), Descr. P1. Nouv.: tab. 3. 1800. Australia.

Gordonia pubescens L'Hér. (Theaceae), Jard. Malmaison 1: tab. 1. 1803 [nom. illeg.]. NORTH AMERICA. = Gordonia pubescens $\mathrm{Cav}$.

Gothofreda cordifolia Vent. (Apocynaceae), Choix Pl.: tab. 60. 1808. SouTH AmericA: Santa Fe de Bogota, Umana s.n. HT: G [G00177309]. $\equiv$ Oxypetalum cordifolium (Vent.) Schltr.

Guarea ramiflora Vent. (Meliaceae) in Mém. Cl. Sci. Math. Inst. Natl. France 8: 20. 1807 [cited in Choix P1. : tab. 41. 1807]. WEST INDIES. Porto Rico, Riedlés.n. HT: G [G00016888]. = Guarea glabra Vahl

Guettarda scabra (L.) Vent. (Rubiaceae), Choix P1.: tab. 1. 1803. WeST INDIES.

Helianthemum alyssoides (Lam.) Vent. (Cistaceae), Choix P1.: tab. 20. 1803. EUROPA. $\equiv$ Halimium alyssoides (Lam.) K. Koch

Heliophila pinnata L. f. (Brassicaceae), Jard. Malmaison 2: tab. 113. 1805. SouTH AFRICA.

Hemerocallis caerulea Andrews (Asphodelaceae), Jard. Malmaison 1: tab. 18. 1803. CHINA. = Hosta ventricosa (Salisb.) Stearn

Heracleum absinthifolium Vent. (Apiaceae), Choix P1.: tab. 7. 1803. [WESTERN AsIA]: LT: G; OM: G-DC; P (28). = Zosima absinthifolia (Vent.) Link

Hibiscus heterophyllus Vent. (Malvaceae), Jard. Malmaison 2: tab. 103. 1805. [AUSTRALIA]: Hort. Malmaison, Ventenat s.n. HT: G [G00341495].

Hypericum dolabriforme Vent. (Hypericaceae), Descr. P1. Nouv.: tab. 45. 1801. NorTh AmERICA: LT (designated by Robson, 1996: 123) : G; ILT : P, P-JU, P-MICH; OM : P-JU (29).

Hypericum heterophyllum Vent. (Hypericaceae), Descr. P1. Nouv.: tab. 68. 1802. [Western AsIA] : Hort. Cels, Ventenat s.n. HT: G [G00341524]; IT : P-JU $\mathrm{n}^{\circ} 11796$ [P006667166].

Hypericum pyramidatum Aiton (Hypericaceae), Jard. Malmaison 2: tab. 118. 1805. NORTH AMERICA. $\equiv$ Hypericum ascyron subsp. pyramidatum (Aiton) N. Robson

Hypericum triplinerve Vent. (Hypericaceae), Descr. P1. Nouv.: tab. 58. 1801. NorTh AMERICA : sur les bords de l'Ohio, Michaux s.n. HT: G [G00341527].

Illicium parviflorum Michx. ex Vent. (Schisandraceae), Tabl. Regn. Veg. 3 : 71. 1799 [cited in Descr. P1. Nouv. tab. 22. 1801]. North AmErica: LT: G; ILT: P, P-JU, P-MICH; OM: G (30).
Indigofera australis Willd. (Leguminosae), Jard. Malmaison 1: tab. 45. 1804. Australia.

Indigofera diphylla Vent. (Leguminosae), Choix P1.: tab. 30. 1804. WEST AFrICA: Dupuis s.n. HT: G [G00341568]; IT: P-JU n 15367 [P00667190].

Indigofera macrostachya Vent. (Leguminosae), Jard. Malmaison 1: tab. 44. 1804. [CHINA]: Hort. Malmaison, Ventenat s.n. HT: G [G00341451].

Inga filipes Vent. (Leguminosae) in Mém. Cl. Sci. Math. Inst. Natl. France 8: 6 . 1807 [cited in Choix P1. : tab. 38. 1807]. WEST INDIEs : Poiteau s.n. LT: G; ILT: G, G-DC (31). „ Cojoba filipes (Vent.) Barneby \& J.W. Grimes

Inula gnaphalodes Vent. (Asteraceae), Descr. P1. Nouv.: tab. 75. 1802. [WESTERN AsIA]: LT: G; OM: G, G-DC, P (32). „ Pulicaria gnaphalodes (Vent.) Boiss.

Ionidium buxifolium Vent. (Violaceae), Jard. Malmaison 1: sub tab. 27. 1803.

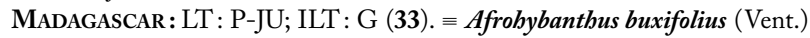
Baill.

Ionidium calceolaria (L.) Vent. (Violaceae), Jard. Malmaison 1: sub tab. 27. 1803. SOUTH AMERICA. $\equiv$ Hybanthus calceolaria (L.) Oken.

Ionidium enneaspermum (L.) Vent. (Violaceae), Jard. Malmaison 1: sub tab. 27. 1803. INDIA. $\equiv$ Afrohybanthus enneaspermus (L.) Flicker

Ionidium glutinosum Vent. (Violaceae), Jard. Malmaison 1: sub tab. 27. 1803. South AmericA: Monte Video, Commerson s.n. HT: G [G00341441]; IT: P-JU n 12786 [P00672091]. = Hybanthus parviflorus (L. f.) Baill.

Ionidium heterophyllum Vent. (Violaceae), Jard. Malmaison 1: sub tab. 27. 1803. ChINA : LT: P-JU; ILT: G (34). = Afrobybanthus enneaspermus (L.) Flicker

Ionidium ipecacuanha (L.) Vent. (Violaceae), Jard. Malmaison 1: sub tab. 27. 1803. Central AMERICA. = Hybanthus calceolaria (L.) Oken.

Ionidium parviflorum (L. f.) Vent. (Violaceae), Jard. Malmaison 1: sub tab. 27. 1803. SOUTH AMERICA. $\equiv$ Hybanthus parviflorus (L. f.) Baill.

Ionidium polygalifolium Vent. (Violaceae), Jard. Malmaison 1: tab. 27. 1803 [nom. inval.]. Central America. = Hybanthus verticillatus (Ortega) Baill.

Ionidium strictum Vent. (Violaceae), Jard. Malmaison 1: sub tab. 27. 1803. WEST INDIES : LT: P-JU; ILT: G-DC, P-JU (35). = Viola stricta (Vent.) Poir.

Iris fimbriata Vent. (Iridaceae), Descr. P1. Nouv.: tab. 9. 1800. [CHINA]: Hort. Cels, Ventenat s.n. HT: G [G00341469]. = Iris japonica Thunb.

Ixia dubia Vent. (Iridaceae), Choix P1.: tab. 10. 1803. [SouTH AfRICA]: Hort. Cels, Ventenat s.n. HT: G [G00190040].

Ixia filiformis Vent. (Iridaceae), Descr. P1. Nouv.: tab. 48. 1801. [SouTH AFRICA] : Hort. Cels, Ventenat s.n. HT: G [G00341467]. = Ixia patens Aiton

Ixia nervosa Vent. (Iridaceae), Choix P1.: sub tab. 10. 1803 [nom. inval.]. SouTH AFRICA. = Ixia maculata L.

Jasminum geniculatum Vent. (Oleaceae), Choix P1.: tab. 8. 1803 [nom. inval.]. NORFOLK ISLAND. = Jasminum simplicifolium subsp. australiense P.S. Green

Jasminum glaucum (L. f.) Aiton (Oleaceae), Descr. P1. Nouv.: tab. 55. 1801. SouTH AFricA.

Jatropha acuminata Lam. (Euphorbiaceae), Jard. Malmaison 1: tab. 52. 1804. WEST INDIES. = Jatropha integerrima Jacq.

Jatropha hernandiifolia Vent. (Euphorbiaceae), Jard. Malmaison 1: sub tab. 52. 1804. WeST INDIES: LT : P; ILT: P-JU (36).

Josephinia imperatricis Vent. (Pedaliaceae), Jard. Malmaison 2: tab. 67. 1804. [Australia]: Hort. Malmaison, Ventenat s.n. HT: G [G00406199].

Justicia orchioides L. f. (Acanthaceae), Jard. Malmaison 1: tab. 51. 1804. SouTH AFRICA.

Kennedia coccinea (Curtis) Vent. (Leguminosae), Jard. Malmaison 2: tab. 105. 1805. Australia.

Kennedia monophylla Vent. (Leguminosae), Jard. Malmaison 2: tab. 106. 1805 [nom. inval.]. Australia. $=$ Hardenbergia violacea $($ Schneev.) Stearn.

Kennedia rubicunda (Schneev.) Vent. (Leguminosae), Jard. Malmaison 2: tab. 104. 1805. Australia. 
Kuhnia rosmarinifolia Vent. (Asteraceae), Descr. P1. Nouv.: tab. 91. 1803. [WEST InDIES]: Hort. Cels, Ventenat s.n. HT: G [G00341474]; IT: P-JU nº 8339 [P00667201]. = Brickellia eupatorioides (L.) Shinners

Laguna squamea Vent. (Malvaceae), Jard. Malmaison 1 : tab. 42.1804 [nom. inval.]. NoRFOLK ISLAND. = Lagunaria patersonia (Andrews) G. Don

Lantana nivea Vent. (Verbenaceae), Jard. Malmaison 1: tab. 8. 1803. SouTH AMERICA : LT: G; ILT: G (37).

Laserpitium triquetrum Vent. (Apiaceae), Descr. P1. Nouv.: tab. 97.1803. [WESTERN AsIA]. LT: G; OM : G-BOIS, P (38). = Heptaptera triquetra (Vent.) Tutin.

Lasiopetalum ferrugineum Sm. (Malvaceae), Jard. Malmaison 1: tab. 59. 1804. Australia.

Lasiopetalum ledifolium Vent. (Malvaceae), Jard. Malmaison 1: sub tab. 59. 1804. Australia: Anon. s.n. HT: G [G00030138]. = Boronia ledifolia (Vent.) DC.

Lavatera acerifolia Cav. (Malvaceae), Jard. Malmaison 2: sub tab. 120. 1805. CANARY IsLANDS. $\equiv$ Malva canariensis M.F. Ray

Lavatera phoenicea Vent. (Malvaceae), Jard. Malmaison 2: tab. 120. 1805. [CANARY IsLands]: Hort. Malmaison, Ventenat s.n. HT: G [G00341498]. = Malva phoenicea (Vent.) Alef.

Leptospermum juniperinum Sm. (Myrtaceae), Jard. Malmaison 2: tab. 89. 1805. Australia.

Leptospermum triloculare Vent. (Myrtaceae), Jard. Malmaison 2: tab. 88. 1805. [Australia]: LT: G; OM: G (39). = Leptospermum arachnoides Gaertn.

Lithospermum decumbens Vent. (Boraginaceae), Descr. P1. Nouv.: tab. 37. 1801. Western AsIA: LT: P; ILT: G-DC; probale ILT: G (40). „ Arnebia decumbens (Vent.) Coss. \& Kralik

Lotus anthylloides Vent. (Leguminosae), Jard. Malmaison 2: tab. 92. 1805. [SouTH AFrICA]: Hort. Malmaison, Ventenat s.n. HT: G [G00341440].

Lotus gebelia Vent. (Leguminosae), Descr. P1. Nouv.: tab. 57. 1801. WesterN AsIA: Syria, Alep, Bruguière E Olivier s.n. HT: G [G00341439].

Lotus lanuginosus Vent. (Leguminosae), Jard. Malmaison 2: sub tab. 92. 1805. [WeSTERN AsIA]: Hort. Cels, Ventenat s.n. HT: G [G00371153].

Lubinia spathulata Vent. (Primulaceae), Descr. P1. Nouv.: tab. 96.1803 [nom. inval.]. MASCARENE ISLANDS. = Lysimachia mauritiana Lam.

Lunaria suffruticosa Vent. (Brassicaceae), Descr. P1. Nouv.: tab. 19. 1800. WESTERN AsIA: LT: G; ILT: G-DC, P; OM: G-DC, P (41). = Fibigia suffruticosa (Vent.) Sweet

Magnolia discolor Vent. (Magnoliaceae), Jard. Malmaison 1: tab. 24. 1803 [nom. inval.]. JAPAN. = Magnolia liliiflora Desr.

Magnolia fasciata Vent. (Magnoliaceae), Jard. Malmaison 1: sub tab. 24. 1803 [nom. inval.]. CHINA. = Magnolia figo (Lour.) DC.

Magnolia pumila Andrews (Magnoliaceae), Jard. Malmaison 1: tab. 37. 1804. CHINA. = Magnolia liliifera $($ L.) Baill.

Maieta annulata Vent. (Melastomataceae) in Mém. Cl. Sci. Math. Inst. Natl. France 8: 11.1807 [cited in Choix P1. : tab. 32. 1807]. INDONESIA : Java, Lahaye s.n. HT: G [G00341515]. = Macrolenes annulata (Vent.) Naudin

Maieta argentea Vent. (Melastomataceae) in Mém. Cl. Sci. Math. Inst. Natl. France 8: 13.1807 [cited in Choix P1. : sub tab. 33. 1807]. SouTH AMERICA: Santa Fe de Bogota, Anon. s.n. HT: G [G00341516]. = Miconia squamulosa (Sm.) Triana

Maieta scalpta Vent. (Melastomataceae) in Mém. Cl. Sci. Math. Inst. Natl. France 8: 12.1807 [cited in Choix P1. : tab. 33. 1807]. WeST INDIES : St Domingo / Haiti, Poiteau s.n. HT: G [G00341572]; IT: G [G00341667]. „OSsaea scalpta (Vent.) DC.

Manulea oppositiflora Vent. (Scrophulariaceae), Jard. Malmaison 1: tab. 15. 1803. [SouTH AFrICA]: Hort. Malmaison, Ventenat s.n. HT: G [G00341530]. = Chaenostoma hispidum (Thunb.) Benth.

Melaleuca ericifolia Sm. (Myrtaceae), Jard. Malmaison 2 : tab. 76.1804.AUSTRALIA.
Melaleuca gnidiifolia Vent. (Myrtaceae), Jard. Malmaison 1: tab. 4. 1803. [Australia]: LT: G; ILT: G-DC (42). = Melaleuca thymifolia Sm.

Melaleuca bypericifolia Sm. (Myrtaceae), Descr. P1. Nouv.: tab. 10. 1800. Australia.

Melaleuca myrtifolia Vent. (Myrtaceae), Jard. Malmaison 1: tab. 47. 1804 Australia: LT: G; OM: G-DC (43). = Melaleuca squarrosa $\mathrm{Sm}$.

Melaleuca nodosa (Sol. ex Gaertn.) Sm. (Myrtaceae), Jard. Malmaison 2: tab. 112. 1805. Australia.

Melastoma cymosum Schrad. \& J.C. Wendl. (Melastomataceae), Jard. Malmaison 1: tab. 14. 1803. SouTH AFricA. = Clidemia cymosa (Schrad. \& J.C. Wendl.) A.H. Liogier

Mercurialis elliptica Lam. (Euphorbiaceae), Descr. P1. Nouv.: tab. 12. 1800. EuROPA.

Meriania ciliaris Vent. (Melastomataceae) in Mém. Cl. Sci. Math. Inst. Natl. France 8: 14. 1807 [cited in Choix P1. : tab. 34. 1807]. South America: Santa Fe de Bogota, Umana s.n. HT: G [G00341509]. „ Tibouchina ciliaris (Vent.) Cogn.

Mesembryanthemum carinatum Vent. (Aizoaceae), Jard.Malmaison 2: tab. 109.1805 [SouTH AFrICA]: LT: (Ventenat, Jard. Malmaison 2: tab. 109. 1805) (44). = Erepsia lacera (Haw.) S. Liede

Mespilus japonica Thunb. (Rosaceae), Jard. Malmaison 1: tab. 19. 1803. CHINA. 三Eriobotrya japonica (Thunb.) Lindl.

Metrosideros anomala Vent. (Myrtaceae), Jard. Malmaison 1: tab. 5. 1803. [Australia]: Hort. Malmaison, Ventenat s.n. HT: G [G00341666]. = Angophora hispida (Sm.) Blaxell

Metrosideros corifolia Vent. (Myrtaceae), Jard. Malmaison 1: tab. 46. 1804. [Australia]: Hort. Malmaison, Ventenat s.n. HT: G [G00223382]. = Kunzea ambigua $(\mathrm{Sm}$.) Druce

Metrosideros floribunda Sm. (Myrtaceae), Jard. Malmaison 2: tab. 75. 1804. Australia.

Metrosideros lophantha Vent. (Myrtaceae), Descr. P1. Nouv.: tab. 69. 1802. [Australia]: LT: G; ILT: G (45). = Callistemon salignus (Sm.) Colv. ex Sweet

Metrosideros saligna Sm. (Myrtaceae), Descr. P1. Nouv.: tab. 70. 1802. Australia. $\equiv$ Callistemon salignus $(\mathrm{Sm}$.) Colv. ex Sweet

Michauxia laevigata Vent. (Campanulaceae), Descr. P1. Nouv.: tab. 81. 1802. WeSTERN AsIA: Iran, Mt. Albours, Bruguière E Olivier s.n. LT (designated by Rechinger \& Schiman-Czeika, 1965 : 48): P [P00235504].

Mimosa botrycephala Vent. (Leguminosae), Descr. P1. Nouv.: tab. 1. 1800 [Australia]: Hort. Cels, Ventenat s.n. HT: G [G00341567]. 三 Acacia botrycephala (Vent.) Desf.

Mimosa decurrens Vent. (Leguminosae), Jard. Malmaison 2: tab. 61. 1804 [nom. illeg.] [non M. decurrens J.C. Wendl.]. [Australia]: Hort. Cels, Ventenat s.n. HT: G [G00341517] [nom. dubium].

Mimosa distachya Vent. (Leguminosae), Descr. P1. Nouv.: tab. 20. 1800 [nom. illeg.] [non $M$. distachya Cav.]. [AusTralia]: Hort. Cels, Ventenat s.n. HT: G [G00341449]. = Paraserianthes lophantha (Willd.) I.C. Nielsen

Mimosa floribunda Vent. (Leguminosae), Choix P1.: tab. 13. 1803. [Australia]: LT: G; ILT: G, G-DC (46). „ Acacia floribunda (Vent.) Willd.

Mimosa glandulosa Michx. (Leguminosae), Choix P1.: tab. 27. 1804. NorTH AMERICA. = Desmanthus illinoensis $($ Michx.) MacMill

Mimosa horridula Michx. (Leguminosae), Choix P1.: tab. 28. 1804. NorTH AMERICA. = Desmanthus illinoensis (Michx.) MacMill.

Mimosa juniperina Vent. (Leguminosae), Jard. Malmaison 2: tab. 64. 1804 [Australia]: LT: G; ILT: G; OM: G (47). = Acacia ulicifolia (Salisb.) Court.

Mimosa linifolia Vent. (Leguminosae), Descr. P1. Nouv.: tab. 2.1800. [AUSTRALIA] : Hort.Cels, Ventenats.n.HT:G[G00341522];IT:P-JUn¹4422 [P00667199]. =Acacia linifolia (Vent.) Willd. 
Mimosa longifolia Andrews (Leguminosae), Jard. Malmaison 2: tab. 62. 1804. Australia. $\equiv$ Acacia longifolia (Andrews) Willd.

Mimosa lophantha Vent. (Leguminosae), Descr. Pl. Nouv.: index 1803 [nom. nov.]. AUSTRALIA. $=$ Paraserianthes lophantha $($ Willd.) I.C. Nielsen

Mimosa pubescens Vent. (Leguminosae), Jard. Malmaison 1: tab. 21. 1803. [AUSTRALIA]: Hort. Malmaison, Ventenat s.n. LT (designated by Kodela \& WiLson, 2017: 30): G [G00341443 left-hand specimen]. „Acacia pubescens (Vent.) R. Br.

Mimosa verticillata L’Hér. (Leguminosae), Jard. Malmaison 2: tab. 63. 1804. Australia. $\equiv$ Acacia verticillata (L'Hér.) Willd.

Mirbelia reticulata Sm. (Leguminosae), Jard. Malmaison 2: tab. 119. 1805. Australia. $=$ Mirbelia rubiifolia $($ Andrews) G. Don

Myrsine retusa Aiton (Myrsinaceae), Descr. P1. Nouv.: tab. 86. 1802. AzorEs. $=$ Myrsine africana $\mathrm{L}$.

Myrtus horizontalis Vent. (Myrtaceae), Jard. Malmaison 1: tab. 60. 1804. [WEST INDIES]: LT: G; ILT: G-DC (48). = Eugenia disticha (Sw.) DC.

Nemesia chamaedrifolia Vent. (Scrophulariaceae), Jard. Malmaison 1: sub tab. 41. 1804 [nom. inval.]. SouTH AFRICA. $=$ Nemesia macrocarpa (Aiton) Druce

Nemesia foetens Vent. (Scrophulariaceae), Jard. Malmaison 1: tab. 41. 1804. [SouTH AFRICA]: LT: G; ILT: G-DC (49). = Nemesia fruticans (Thunb.) Benth.

Nemesia linearis Vent. (Scrophulariaceae), Jard. Malmaison 1: sub tab. 41. 1804. SouTH AFrica: Cape, Sonnerat s.n. LT: P-JU (50).

Nepeta longiflora Vent. (Lamiaceae), Descr. P1. Nouv.: tab. 66. 1802. [WESTERN AsIA] : LT: G; ILT: P-JU; OM: G-BOIS, G-DC (51).

Nicotiana undulata Vent. (Solanaceae), Jard. Malmaison 1: tab. 10. 1803 [nom. illeg.] [non N. undulata Ruiz \& Pav.]. [AusTraLia]: LT: G; ILT: G (52). $\equiv$ Nicotiana suaveolens $\mathrm{Lehm}$.

Notelaea ligustrina Vent. (Oleaceae), Choix P1.: sub tab. 25. 1804. Australia: Golfe d'Entrecasteaux, Leschenault de la Tour s.n. LT: P-JU; ILT: G (53).

Notelaea longifolia Vent. (Oleaceae), Choix Pl.: tab. 25. 1804. [AUSTRALIA]: Hort. Cels, Ventenat s.n. HT: G [G00406213].

Nycterium cardaminefolium Vent. (Solanaceae), Jard. Malmaison 2: sub tab. 85. 1805 [nom. inval.]. Central America. $=$ Solanum angustifolium Mill.

Nycterium cordifolium Vent. (Solanaceae), Jard. Malmaison 2: tab. 85. 1805 [nom. inval.]. CANARY IsLANDS. $=$ Solanum vespertilio Aiton

Nymphaea caerulea Savigny (Nymphaeaceae), Jard. Malmaison 1: tab. 6. 1803. SOUTH AFRICA. $\equiv$ Nymphaea nouchali var. caerulea (Savigny) Verdc.

Oliveria decumbens Vent. (Apiaceae), Descr. P1. Nouv.: tab. 21. 1801. [WESTERN AsIA]: LT: G; ILT: G, P-JU n ${ }^{\circ}$ 10396; OM: G-DC (54).

Ononis vaginalis Vahl (Leguminosae), Descr. Pl. Nouv.: tab. 32. 1801. NORTH Africa.

Orobus saxatilis Vent. (Leguminosae), Descr. P1. Nouv.: tab. 94. 1803. [EuRoPA]: Hort. Cels, Ventenat s.n. HT: G [G00341444]. = Lathyrus saxatilis (Vent.) Vis.

Parnassia asarifolia Vent. (Parnassiaceae), Jard. Malmaison 1: tab. 39. 1804. [NorTh AMERICA]: Hort. Malmaison, Ventenat s.n. HT: G [G00341552].

Pastinaca dissecta Vent. (Apiaceae), Descr. P1. Nouv.: tab. 78. 1802. [WeSTERN AsIa]: Hort. Cels, Ventenat s.n. HT: G [G00341559].

Pelargonium radicatum Vent. (Geraniaceae), Jard. Malmaison 2: tab. 65. 1804. [South Africa]: HT: G [G00341658] (55).

Penaea mucronata L. (Penaeaceae), Jard. Malmaison 2: tab. 87. 1805. SoutH AFrica.

Persoonia linearis Andrews (Proteaceae), Jard. Malmaison 1: tab. 32. 1804. Australia.

Phebalium squamulosum Vent. (Rutaceae), Jard. Malmaison 2: tab. 102. 1805. [Australia]: LT: G; ILT: G-DC (56).

Phlomis samia L. (Lamiaceae), Choix P1.: tab. 4. 1803. Western AsIA.
Phlox reptans Michx. (Polemoniaceae), Jard. Malmaison 2: tab. 107. 1805. NoRTH AMERICA. $=$ Phlox stolonifera Sims

Phlox suffruticosa Vent. (Polemoniaceae), Jard. Malmaison 2: sub tab. 107. 1805. [NorTh AMERICA]: Hort. Malmaison, Ventenat s.n. HT: G [G00341555]. = Phlox carolina L. s.l.

Phylica divaricata Vent. (Rhamnaceae), Jard. Malmaison 1: sub tab. 57. 1804. [SouTH AFrICA]: Hort. Malmaison, Ventenat s.n. HT: G [G00341603]. = Phylica paniculata Willd.

Phylica horizontalis Vent. (Rhamnaceae), Jard. Malmaison 1: sub tab. 57. 1804. [SouTH AFrica]: Hort. Malmaison, Ventenat s.n. HT: G [G00341574]. = Phylica plumosa L.

Phylica oleifolia Vent. (Rhamnaceae), Jard. Malmaison 1: sub tab. 57. 1804. [SOUTH AFrICA] : NT: P-JU (57).

Phylica squarrosa Vent. (Rhamnaceae), Jard. Malmaison 1: sub tab. 57. 1804. [SouTh AFrICA]: LT: G; ILT: G-DC (58). = Phylica plumosa L.

Phylica thymifolia Vent. (Rhamnaceae), Jard. Malmaison 1: tab. 57. 1804. [Australia]: LT: G; ILT: G-DC (59).

Phyteuma pinnatum L. (Campanulaceae), Descr. P1. Nouv.: tab. 52. 1801. WeSTERn Asia. $\equiv$ Petromarula pinnata (L.) A. DC.

Picridium ligulatum Vent. (Asteraceae), Jard. Malmaison 2: tab. 68. 1804. [NORTH AFrICA]: LT: G; OM: G-DC (60). = Reichardia ligulata (Vent.) G. Kunkel \& Sunding

Pittosporum undulatum Vent. (Pittosporaceae), Descr. Pl. Nouv.: tab. 76. 1802. [CANARY IsLANDS]: Hort. Malmaison, Ventenat s.n. HT: G [G00406203].

Plantago vaginata Vent. (Plantaginaceae), Descr. P1. Nouv.: tab. 29. 1801. [NoRTH AFRICA]: Hort. Cels, Ventenat s.n. HT: G [G00341426]. = Plantago lagopus L.

Platylobium formosum Sm. (Leguminosae), Jard. Malmaison 1: tab. 31. 1804. Australia.

Platylobium obcordatum Vent. (Leguminosae), Jard. Malmaison 1: sub tab. 31. 1804. Australia: LT: G; OM: G (61). „ Bossiaea obcordata (Vent.) Druce.

Platylobium scolopendrium Andrews (Leguminosae), Jard. Malmaison 1: tab. 55. 1804. Australia.

Podalyria australis (L.) Willd. (Leguminosae), Descr. P1. Nouv.: tab. 56. 1801. NORTH AMERICA. $\equiv$ Baptisia australis (L.) R. Br.

Podalyria cuneifolia Vent. (Leguminosae), Descr. P1. Nouv.: tab. 99. 1803. [SouTH Africa]: Hort. Cels, Ventenat s.n. HT: G [G00341589]; IT: P-LAM [P00295866], G-DC [G00488125].

Poiretia scandens Vent. (Leguminosae) in Mém. Cl. Sci. Math. Inst. Natl. France 8: 4.1807 [cited in Choix P1. : tab. 42. 1807]. WEST INDIES: Dominican Republic / Haiti: Poiteau s.n. HT: G [G00341442]; IT: G [G00341676], G-DC [G00479632], P-JU n 1561 [P00678637]. = Poiretia punctata (Willd.) Desv.

Poitea galegoides Vent. (Leguminosae) in Mém. Cl. Sci. Math. Inst. Natl. France 8: 17. 1807 [cited in Choix P1. : tab. 36. 1807]. WeST INDIES: HT: G; IT: $\mathrm{P}(62)$.

Polygonum acetosifolium Vent. (Polygonaceae), Descr. P1. Nouv.: tab. 88. 1802. [SOUTH AMERICA]: Hort. Cels, Ventenat s.n. HT: G [G00341374]. = Mueblenbeckia sagittifolia (Ortega) Meisn.

Polygonum polygamum Vent. (Polygonaceae), Descr. Pl. Nouv.: tab. 65. 1802. North America: LT: G; OM: G, P-JU (63). „ Polygonella polygama (Vent.) Engelm. \& A. Gray

Pongamia glabra Vent. (Leguminosae), Jard. Malmaison 1: tab. 28. 1803 [nom. inval.]. INDIA. $=$ Pongamia pinnata $($ L.) Pierre

Pongamia grandiflora Vent. (Leguminosae), Jard. Malmaison 1: sub tab. 28. 1803. InDONESIA: Java, Lahaye s.n. LT (designated by Adema 2000: 420): P-JU $\mathrm{n}^{\circ} 15666$ [P00667171]. = Derris elliptica $($ Wall.) Benth.

Pongamia sericea Vent. (Leguminosae), Jard. Malmaison 1: sub tab. 28. 1803. INDONESIA: LT: P; ILT: P (64). = Millettia sericea (Vent.) Benth. 
Primula auriculata Lam. (Primulaceae), Descr. P1. Nouv.: tab. 42. 1801. WESTERN Asia.

Psoralea melilotoides Michx. (Leguminosae), Jard. Malmaison 2: tab. 94. 1805. NORTH AMERICA. = Orbexilum pedunculatum var. gracile (Torr. \& A. Gray) J.W. Grimes

Pultenaea ericoides Vent. (Leguminosae), Jard. Malmaison 1: tab. 35. 1804. [Australia]: LT: G; ILT: G-DC (65). $\equiv$ Aotus ericoides (Vent.) G. Don

Rafnia retusa Vent. (Leguminosae), Jard. Malmaison 1: tab. 53. 1804. [Australia]: LT: G; OM: G (66). „ Templetonia retusa (Vent.) R. Br.

Rafnia triflora (L.) Thunb. (Leguminosae), Jard. Malmaison 1: tab. 48. 1804. SOUTH AFrica.

Ranunculus echinatus Vent. (Ranunculaceae), Descr. P1. Nouv.: tab. 73. 1802. [NorTh AMERICA]: Hort. Cels, Ventenat s.n. LT: G; ILT: G-DC (67). = Ranunculus muricatus $\mathrm{L}$.

Ranunculus ventricosus Vent. (Ranunculaceae), Descr. P1. Nouv.: sub tab. 73. 1802. South America: "Buenos Aires / Montevideo", Commerson s.n. HT: G [G00341601]; IT: P-JU n 10637 [P00671597]. = Ranunculus muricatus L.

Redoutea heterophylla Vent. (Malvaceae), Descr. P1. Nouv.: tab. 11. 1800. WEST INDIES: LT (first step designated by Fryxell, 1969: 211; second step designated here): G; ILT: FI, P, P-JU; OM: G (68). = Cienfuegosia heterophylla (Vent.) Garcke

Rhamnus glandulosa Aiton (Rhamnaceae), Jard. Malmaison 1: tab. 34. 1804. CANARY IsLANDS.

Rhododendron punctatum Andrews (Ericaceae), Descr. Pl. Nouv.: tab. 15. 1800. NORTH AMERICA.

Riedlea crenata Vent. (Malvaceae), Choix Pl.: sub tab. 37.1807 [nom. inval.]. SOUTH AMERICA. = Melochia crenata Vahl

Riedlea serrata Vent. (Malvaceae) in Mém. Cl. Sci. Math. Inst. Natl. France 8: 2. 1807 [cited in Choix P1.: tab. 37. 1807]. West INDIEs: PortoRico, Riedlé s.n HT: G [G00341560]; IT: P-JU nº 12489 [P00672019]. = Melochia villosa (Mill.) Fawc. \& Rendle

Robinia viscosa Vent. (Leguminosae), Descr. P1. Nouv.: tab. 4. 1800. [NORTH AMERICA]: LT: G; ILT: P-JU; OM: G, G-DC, P, P-MICH (69).

Rosa bracteata J.C. Wendl. (Rosaceae), Descr. P1. Nouv.: tab. 28. 1801. China.

Rosa diversifolia Vent. (Rosaceae), Descr. P1. Nouv.: tab. 35. 1801. [CHINA]: Hort. Cels, Ventenat s.n. HT: G [G00341558]. = Rosa chinensis var. semperflorens (W.M. Curtis) Koehne

Rosa kamtchatica Vent. (Rosaceae), Descr. P1. Nouv.: tab. 67. 1802. [RusSIAN FAR EAST]: LT: G; ILT: G (70).

Royena ambigua Vent. (Ebenaceae), Jard. Malmaison 1: tab. 17. 1803 [nom. illeg.] [non $R$. ambigua Salisb.]. [SouTH Africa]: Hort. Malmaison, Ventenat s.n. HT: G [G00341575]. = Diospyros austroafricana De Winter

Rudbeckia pinnata Vent. (Asteraceae), Descr. P1. Nouv.: tab. 71. 1802. NoRTH AMERICA: Michaux s.n. HT: G [G00341472]; IT: P [P02513854]. $\equiv$ Ratibida pinnata (Vent.) Barnhart

Ruellia varians Vent. (Acanthaceae), Descr. P1. Nouv.: tab. 46. 1801 [nom. inval.]. NEW ZEALAND. $=$ Eranthemum pulchellum Andrews

Salvia acuminata Vent. (Lamiaceae), Descr. P1. Nouv.: tab. 50. 1801 [nom. illeg.] [non S. acuminata Ruiz \& Pav.]. North AMERICA: LT: G; ILT: P-JU; OM: G (71). = Salvia azurea Michx. ex Vahl

Salvia compressa Vent. (Lamiaceae), Descr. P1. Nouv.: tab. 59. 1801. [WESTERN AsIA]: LT: G; ILT: C; OM: G-BOIS, P (72).

Samyda spinulosa Vent. (Salicaceae) in Mém. Cl. Sci. Math. Inst. Natl. France 8: 150. 1808 [cited in Choix P1.: tab. 43. 1808]. WeST InDIEs: St. Thomas, Riedlés.n. HT: G [G00364207].

Scandix pinnatifida Vent. (Apiaceae), Descr. Pl. Nouv.: tab. 14. 1800. WeSTERN AsIA: Perse, Bruguière \& Olivier s.n. HT: G [G00341470]; IT: P [P03260537]. = Scandix stellata Banks \& Sol.
Scutellaria incarnata Vent. (Lamiaceae) in Mém. Cl. Sci. Math. Inst. Natl. France 8: 18.1807 [cited in Choix P1. : tab. 39. 1807]. South AMERICA: Santa Fe de Bogota, Umana s.n. HT: G [G00435777].

Selago lucida Vent. (Scrophulariaceae), Jard. Malmaison 1: tab. 26. 1803. [SouTH AFrica]: LT (designated by Hilliard, 1999: 12): (Ventenat, Jard. Malmaison 1: tab. 26. 1803). = Microdon bracteatus $($ Thunb.) Hartley

Sideritis pullulans Vent. (Lamiaceae), Descr. P1. Nouv.: tab. 98. 1803. WeSTERN AsIA: LT: G; OM: G (73).

Silene longipetala Vent. (Caryophyllaceae), Descr. Pl. Nouv.: tab. 83. 1802. [WESTERN AsIA]: Hort. Cels, Ventenat s.n. HT: G [G00341514].

Solenandria cordifolia P. Beauv. ex Vent. (Diapensiaceae), Jard. Malmaison 2: tab. 69. 1804. NorTh America: LT: G; ILT: G (74). = Galax urceolata (Poir.) Brummitt

Sparrmannia africana L.f. (Malvaceae), Jard. Malmaison 2: tab. 78. 1804. SoutH AFrica.

Spartium parviflorum Vent. (Leguminosae), Descr. P1. Nouv.: tab. 87. 1802. [Western Asia]: LT: G; ILT: G; OM: G, G-DC, P (75). = Genista angulata $(\mathrm{L}$.$) Lam.$

Spartium sericeum Vent. (Leguminosae), Choix P1.: tab. 17. 1803 [nom. illeg.] [non S. sericeum Aiton]. CANARY IsLANDS: Broussonet s.n. HT: G [G00341546]. = Genista clavata Poir.

Spathodea corymbosa Vent. (Bignoniaceae) in Mém. Cl. Sci. Math. Inst. Natl. France 8: 19. 1807 [cited in Choix P1. : tab. 40. 1807]. West InDIES: HT: P (76). = Bignonia corymbosa (Vent.) L.G. Lohmann

Statice fasciculata Vent. (Plumbaginaceae), Descr. P1. Nouv.: tab. 38. 1801. [EUROPA]: LT: G; OM: FI-W, P, P-TRF (77). = Armeria pungens $($ Link) Hoffmanns. \& Link

Sterculia grandiflora Vent. (Malvaceae), Jard. Malmaison 2: sub tab. 91. 1805 MASCARENE IsLANDS: LT: P-JU; ILT: G; OM: P-LA (78). = Cola acuminata (P. Beauv.) Schott \& Endl.

Sterculia longifolia Vent. (Malvaceae), Jard. Malmaison 2: sub tab. 91. 1805. INDONESIA: "Indes", Lahaye s.n. HT: G [G00358563]; IT: P-JU n 12444 [P00667184].

Sterculia macrophylla Vent. (Malvaceae), Jard. Malmaison 2: sub tab. 91. 1805 INDONESIA: Java, Lahaye s.n. HT: G [G00358565]; IT: P-JU n ${ }^{\circ} 12450$ [P00667177].

Sterculia monosperma Vent. (Malvaceae), Jard. Malmaison 2: tab. 91. 1805. [China]: LT (first step designated by TANTRA, 1976: 154; second step designated here): G; OM: G (79).

Sterculia nitida Vent. (Malvaceae), Jard. Malmaison 2: sub tab. 91. 1805. [WEST AfrICA]: Cult. in Mauritius, Michaux s.n. HT: G [G00015680]; IT: P [P06655301, P06655303, P06655304, P06655305]. Cola nitida (Vent.) Schott \& Endl.

Sterculia rubiginosa Vent. (Malvaceae), Jard. Malmaison 2: sub tab. 91. 1805. INDONESIA: LT: P-JU; ILT: P; OM: LINN (80).

Styphelia gnidium Vent. (Epacridaceae), Jard. Malmaison 1: tab. 23. 1803. [AUSTRALIA]: LT: P-JU; OM: G (81). = Leucopogon parviflorus (Andrews) Lindl.

Tagetes papposa Vent. (Asteraceae), Descr. P1. Nouv.: tab. 36. 1801. [NorTh America]: Hort. Cels, Ventenat s.n. HT: G [G00341538]. $\equiv$ Dyssodia papposa (Vent.) Hitchc.

Tiarella biternata Vent. (Saxifragaceae), Jard. Malmaison 1: tab. 54. 1804. [NORTH AMERICA]: Hort. Malmaison, Ventenat s.n. HT: G [G00341466]; IT: P-JU $\mathrm{n}^{\circ} 13453$ [P00667205]. $\equiv$ Astilbe biternata (Vent.) Britton

Tournefortia laurifolia Vent. (Boraginaceae), Choix P1.: tab. 2.1803. WEST INDIES: LT: P; ILT: P (82). = Tournefortia maculata Jacq. 
Tournefortia mutabilis Vent. (Boraginaceae), Choix P1.: tab. 3. 1803. [INDONESIA]: Hort. Cels, Ventenat s.n. HT: G [G00386071]; IT: GH [GH00096883]. = Tournefortia maculata Jacq.

Tradescantia rosea Vent. (Commelinaceae), Descr. Pl. Nouv.: tab. 24. 1801. NoRTH AMERICA: HT: G; IT P, P-MICH (83). $\equiv$ Callisia rosea (Vent.) D.R. Hunt

Tristemma virusanum Juss. (Melastomataceae) in Mém. Cl. Sci. Math. Inst. Natl. France 8: 15. 1807 [cited in Choix Pl.: tab. 35. 1807]. Madagascar. = Tristemma mauritianum J.F. Gmel.

Turpinia paniculata Vent. (Staphyleaceae) in Mém. Cl. Sci. Math. Inst. Natl. France 8: 3.1807 [cited in Choix P1. : tab. 31. 1807]. WEST INDIES : LT : G; ILT: G, G-DC, P-JU (84). = Turpinia occidentalis (Sw.) G. Don

Turraea rigida Vent. (Meliaceae), Choix P1.: tab. 48. 1808. MASCARENE IsLANDS: Mauritius, Riche s.n. HT: G [G00341518].

Verbena mutabilis Jacq. (Verbenaceae), Jard. Malmaison 1: tab. 36. 1804. SouTH AFRICA. $\equiv$ Stachytarpheta mutabilis (Jacq.) Vahl

Verbena stricta Vent. (Verbenaceae), Descr. P1. Nouv.: tab. 53. 1801. NoRTH AMERICA: LT: G; ILT: G, P, P-MICH; OM: G-DC (85).

Veronica gentianoides Vahl (Plantaginaceae), Jard. Malmaison 2: tab. 86. 1805. WESTERN AsIA.

Viburnum acerifolium L. (Adoxaceae), Descr. P1. Nouv.: tab. 72. 1802. NoRTH AMERICA.
Viburnum rigidum Vent. (Caprifoliaceae), Jard. Malmaison 2: tab. 98. 1805. [MAdeIRA]: LT (designated by Moura et al., 2015: 18): (Ventenat, Jard. Malmaison 2: tab. 98. 1805). = Viburnum rugosum Persoon

Vicia atropurpurea Desf. (Leguminosae), Descr. P1. Nouv.: tab. 84. 1802. NoRTH AFRICA. = Vicia benghalensis $\mathrm{L}$.

Villarsia lacunosa Vent. (Menyanthaceae), Choix P1.: sub tab. 9.1803 [nom. inval.]. NORTH AMERICA. = Nymphoides cordata (Elliot) Fernald

Villarsia nymphoides (L.) Vent. (Menyanthaceae), Choix Pl.: sub tab. 9. 1803. EUROPA. $\equiv$ Limnanthemum nymphoides (L.) Hoffmanns. \& Link

Villarsia ovata (L. f.), Vent. (Menyanthaceae), Choix P1.: tab. 9.1803 [nom. inval.]. SOUTH AFrICA. = Villarsia capensis (Houtt.) Merr.

Volkameria fragrans Vent. (Lamiaceae), Jard. Malmaison 2: tab. 70. 1804. [INDONESIA]: Hort. Noisette, Ventenat s.n. HT: G [G00341433]. = Clerodendrum chinense (Osbeck) Mabb.

Volkameria heterophylla Vent. (Lamiaceae), Jard. Malmaison 2: sub tab. 70. 1804. Mascarene IsLands: Mauritius, Riche s.n. HT: G [G00368624]. $\equiv$ Clerodendrum heterophyllum (Vent.) $\mathrm{R}$. Br.

Volkameria tomentosa Vent. (Lamiaceae), Jard. Malmaison 2: tab. 84. 1804. [Australia]: LT (designated by Verdcourt, 1989: 696): (Ventenat, Jard. Malmaison 2: tab. 84. 1804). $\equiv$ Clerodendrum tomentosum (Vent.) R. Br.

Xeranthemum bracteatum Vent. (Asteraceae), Jard. Malmaison 1: tab. 2. 1803. [Australia]: Hort. Malmaison, Ventenat s.n. HT: G [G00341478]. 三Xerochrysum bracteatum (Vent.) Tzvelev. 